\title{
Review
}

\section{(In)Distinctive Role of Long Non-Coding RNAs in Common and Rare Ovarian Cancers}

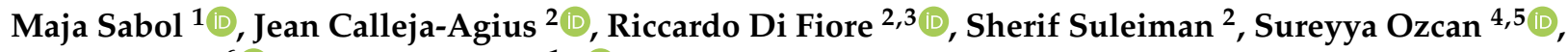 \\ Mark P. Ward ${ }^{6}(\mathbb{1})$ and Petar Ozretić ${ }^{1, *}$
}

1 Laboratory for Hereditary Cancer, Division of Molecular Medicine, Ruđer Bošković Institute, HR-10000 Zagreb, Croatia; maja.sabol@irb.hr

2 Department of Anatomy, Faculty of Medicine and Surgery, University of Malta, MSD 2080 Msida, Malta; jean.calleja-agius@um.edu.mt (J.C.-A.); riccardo.difiore@um.edu.mt (R.D.F.); sherif.s.suleiman@um.edu.mt (S.S.)

3 Sbarro Institute for Cancer Research and Molecular Medicine, Center for Biotechnology, College of Science and Technology, Temple University, Philadelphia, PA 19122, USA

4 Department of Chemistry, Middle East Technical University (METU), 06800 Ankara, Turkey; sozcan@metu.edu.tr

5 Cancer Systems Biology Laboratory (CanSyl), Middle East Technical University (METU), 06800 Ankara, Turkey

6 Department of Histopathology, Trinity St James's Cancer Institute, Emer Casey Molecular Pathology Laboratory, Trinity College Dublin and Coombe Women's and Infants University Hospital, D08 RX0X Dublin, Ireland; wardm6@tcd.ie

* Correspondence: pozretic@irb.hr; Tel.: +385-(1)-4571292

check for updates

Citation: Sabol, M.; Calleja-Agius, J.; Di Fiore, R.; Suleiman, S.; Ozcan, S.; Ward, M.P.; Ozretić, P. (In)Distinctive Role of Long Non-Coding RNAs in Common and Rare Ovarian Cancers. Cancers 2021, 13, 5040. https:// doi.org/10.3390/cancers13205040

Academic Editor: Lyndsay Rhodes

Received: 6 September 2021

Accepted: 6 October 2021

Published: 9 October 2021

Publisher's Note: MDPI stays neutral with regard to jurisdictional claims in published maps and institutional affiliations.

Copyright: (c) 2021 by the authors. Licensee MDPI, Basel, Switzerland. This article is an open access article distributed under the terms and conditions of the Creative Commons Attribution (CC BY) license (https:// creativecommons.org/licenses/by/ $4.0 /)$.
Simple Summary: Ovarian cancers (OCs) are the most lethal form of gynecological tumors. The commonest are high-grade serous OCs, while rare OCs originate from many different cell types, such as epithelial, germ cell, sex cord-stromal, or mixed types. Rare OCs have distinct molecular characteristics, prognosis, and therapeutic approaches. However, all ovarian malignancies mostly share the same problem: late diagnosis due to the lack of specific symptoms. Therefore, there is a perpetual need to discover better diagnostic, prognostic, and predictive biomarkers, as well as new therapeutic approaches. In recent years, long non-coding RNAs (lncRNAs) have gained widespread attention because of their important role in various biological pathways. They have multiple mechanisms of action with an important role in many cellular processes related to OCs development and progression. This review will focus on the different aspects of lncRNAs in OCs and attempt to highlight the distinctive role of lncRNAs in common and rare OCs.

Abstract: Rare ovarian cancers (ROCs) are OCs with an annual incidence of fewer than 6 cases per 100,000 women. They affect women of all ages, but due to their low incidence and the potential clinical inexperience in management, there can be a delay in diagnosis, leading to a poor prognosis. The underlying causes for these tumors are varied, but generally, the tumors arise due to alterations in gene/protein expression in cellular processes that regulate normal proliferation and its checkpoints. Dysregulation of the cellular processes that lead to cancer includes gene mutations, epimutations, non-coding RNA (ncRNA) regulation, posttranscriptional and posttranslational modifications. Long non-coding RNA (lncRNA) are defined as transcribed RNA molecules, more than $200 \mathrm{nu}$ cleotides in length which are not translated into proteins. They regulate gene expression through several mechanisms and therefore add another level of complexity to the regulatory mechanisms affecting tumor development. Since few studies have been performed on ROCs, in this review we summarize the mechanisms of action of lncRNA in OC, with an emphasis on ROCs.

Keywords: rare ovarian cancers; long non-coding RNAs; lncRNAs; competing endogenous RNA; ceRNA; MALAT1; ovarian cancer biomarkers; lncRNA-based therapy 


\section{Introduction}

Gynecologic malignancies comprise about 19\% of all cancers diagnosed in women, and out of these more than $50 \%$ are classified as rare [1]. They encompass more than 30 different histologic diagnoses of various sites, such as vulva, vagina, uterine cervix and corpus, fallopian tube, and ovary. Ovarian cancers (OCs) are the deadliest of all gynecological malignancies, and in 2020 there were around 314,000 new cases and 207,000 deaths related to them around the globe [2]. They mostly fall into the epithelial subtype based on the cell of origin, and the most malignant but also the most common type is the high-grade serous OC (HGSOC) [3]. Rare cancers are usually defined as malignancies that have an incidence of $<6$ cases per 100,000 [4]. Rare ovarian cancers (ROCs) are malignancies of the ovary which can originate from different cell types, such as epithelial, germ cell, sex cord-stromal, or mixed types [5]. Ovarian malignancies mostly share the same problem, which is late diagnosis [6]. ROC malignancies lack distinguishable symptoms during the early stages of disease development, which means that most cancers are diagnosed late when they have already progressed to advanced stages of the disease and are therefore more difficult to treat. This is especially true for ROCs, as they can be misdiagnosed due to their rarity and clinical inexperience. This results in poor outcomes for these patients and stresses the need for reliable markers for early diagnosis and potential specific targets for therapy. In recent years, one class of macromolecules called long non-coding RNAs (lncRNAs) has been emerging as promising diagnostic and prognostic biomarkers, as well as potential therapeutic targets, for many different types of cancers [7]. Although the role of lncRNAs in OCs has been extensively reviewed previously [8-15], this is, to the best of our knowledge, the first effort to differentiate the role of $\operatorname{lncRNAs}$ between common and rare OCs.

Generally, a major drawback in the research on ROCs is the lack of studies that separate the OC subtypes, as in most cases the samples are just classified as OC. Most studies examine OC in general or focus on the most prevalent HGSOC subtype. Even LGSOC is not well characterized within these studies, which makes analyzing available data difficult, and possibly misleading. Therefore, this review will outline the lncRNAs associated with OC in general, with the OC subtype defined where available, focusing on ROCs when possible.

\section{Common Versus Rare Ovarian Cancers}

OC is a major cause of morbidity and mortality in women, with minimal improvement in survival rates over the past decades [16]. OC is divided into epithelial and non-epithelial subgroups. However, OC is a heterogeneous malignancy with diverse pathophysiology and clinical development. In the case of epithelial ovarian cancers (EOCs), the majority of tumors originate outside the ovary, while only a subset develops within the ovarian surface epithelium [17]. Approximately $90 \%$ of OCs belong to the malignant epithelial tumor (carcinomas) group, and there are currently five main subtypes of carcinoma: highgrade serous ovarian carcinoma (HGSOC), low-grade serous ovarian carcinoma (LGSOC), endometrioid carcinoma; clear cell carcinoma, and mucinous carcinoma [18]. HGSOC and endometrioid cancers are considered common OCs, while the others are deemed to be rare. Table 1 summarizes the most common molecular alterations as well as the prognosis of different types of ovarian cancers.

HGSOCs are chromosomally unstable tumors that commonly have mutations in the TP53 tumor suppressor gene [19]. In most cases, there are also germline or somatic mutations in $B R C A 1$ or $B R C A 2$, or hypermethylation of $B R C A 1$ promoter with a loss of expression. The underlying loss of BRCA1/2 function and inability to repair double-strand repair breaks, which in turn leads to chromosomal instability, lead to a potential role for drugs targeting the DNA repair (e.g., PARP inhibitors) [20]. The PI3K-AKT pathway plays an important role in HGSOC [3]. The 5-year overall survival rates are $84.0 \%, 67.7 \%$, and $32.1 \%$ for stage IA/IB, IC/II, and III/IV HGSOC, respectively [21]. 
Table 1. Molecular alterations and prognosis of different types of ovarian cancers.

\begin{tabular}{|c|c|c|c|c|c|}
\hline Cancer Type & $\begin{array}{l}\text { Common or } \\
\text { Rare }\end{array}$ & Molecular Alterations & Altered Pathways & Prognosis & Reference \\
\hline \multicolumn{6}{|l|}{ Epithelial } \\
\hline $\begin{array}{l}\text { High-Grade } \\
\text { Serous Ovarian } \\
\text { Carcinoma } \\
\text { (HGSCO) }\end{array}$ & Common & $\begin{array}{l}\text { Genomic Instability, } \\
B R C A 1, B R C A 2, T P 53,\end{array}$ & PI3K-AKT & $\begin{array}{c}\text { Almost } 30 \% \text { of Patients } \\
\text { Die within 5-years of } \\
\text { Diagnosis }\end{array}$ & {$[3,19,20]$} \\
\hline $\begin{array}{l}\text { Low-Grade } \\
\text { Serous Ovarian } \\
\text { Carcinoma } \\
\text { (LGSOC) }\end{array}$ & Rare & $\begin{array}{c}\text { KRAS, BRAF, ERBB2, } \\
\text { PIK3CA, FFAR1, USP9X } \\
\text { and EIF1AX }\end{array}$ & $\begin{array}{l}\text { MAPK and } \\
\text { AKT-mTOR }\end{array}$ & $\begin{array}{c}\text { Better than } \\
\text { The High-Grade Serous } \\
\text { Cancer }\end{array}$ & [22] \\
\hline $\begin{array}{l}\text { Endometrioid } \\
\text { Carcinoma (EC) }\end{array}$ & Common & $\begin{array}{c}\text { CTNNB1, CDKN2A, } \\
\text { PIK3CA, KRAS, ARID1A, } \\
\text { PTEN, and PPP2R1A }\end{array}$ & $\begin{array}{l}\text { WNT, MAPK/RAS } \\
\text { and PI3K }\end{array}$ & Good & {$[19,20]$} \\
\hline $\begin{array}{l}\text { Ovarian Clear } \\
\text { Cell Carcinoma } \\
\text { (OCCC) }\end{array}$ & Rare & $\begin{array}{c}\text { ARI1D1A, } \\
\text { PI3KCA, PPP2R1A and } \\
\text { KRAS }\end{array}$ & PI3K and mTOR & $\begin{array}{l}\text { Favorable Compared } \\
\text { with The Serous Cancer }\end{array}$ & [23-25] \\
\hline $\begin{array}{l}\text { Mucinous } \\
\text { ovarian } \\
\text { carcinoma } \\
\text { (MOC) }\end{array}$ & Rare & $\begin{array}{l}\text { High Microsatellite } \\
\text { Instability (MSI-H), } \\
K R A S, \text { CTNNB1, or APC }\end{array}$ & WNT & $\begin{array}{l}\text { Worse than Advanced } \\
\text { Stage Serous Cancer }\end{array}$ & {$[23,26-28]$} \\
\hline $\begin{array}{l}\text { Non-Epithelial } \\
\text { Sex-Cord }\end{array}$ & & & & & \\
\hline $\begin{array}{l}\text { Stromal Tumors } \\
\text { (Granulosa Cell } \\
\text { Tumors) } \\
\text { Sex-Cord }\end{array}$ & Rare & FOXL2 & $\begin{array}{l}\text { PI3K/AKT, TGF- } \beta \text {, } \\
\text { and Notch }\end{array}$ & Good & [29-32] \\
\hline $\begin{array}{l}\text { Stromal Tumors } \\
\text { (Sertoli-Leydig } \\
\text { Cell Tumors) }\end{array}$ & Rare & DICER1, FOXL2 & Unknown & Good & [33] \\
\hline $\begin{array}{l}\text { Germ-Cell } \\
\text { Tumors }\end{array}$ & Rare & $K I T, K R A S$ & Unknown & Unknown & [34] \\
\hline
\end{tabular}

Endometrioid carcinomas (EC) are the second commonest malignant ovarian neoplasm, accounting for $8-15 \%$ of all ovarian carcinomas. There is a strong association with endometriosis. Most EC is grade 1 or 2 . Since at presentation they are predominantly low stage and low grade, the burden of morbidity and mortality associated with this subtype is relatively low, despite being common. The 5-year overall survival rates are $87.1 \%, 83.9 \%$, and $44.7 \%$ for stage IA/IB, IC/II, and III/IV EC, respectively [21]. There are no data currently available specifically on the benefit of adjuvant chemotherapy in patients with advanced-stage $\mathrm{EC}$, and such data will be hard to acquire given the rarity of advanced-stage or recurrent tumors. Genes that are typically mutated in EC include CTNNB1, CDKN2A, PIK3CA, KRAS, ARID1A, PTEN, and PPP2R1A [20]. Moreover, the MAPK/RAS, WNT, and PI3K pathways could be good candidate targets for molecular therapeutics [35].

LGSOC represent $<5 \%$ of all ovarian serous carcinomas, affecting younger women with a median age of under 55 years. The 5 -year overall survival rates are $93.2 \%, 82.7 \%$, and $54.2 \%$ for stage IA/IB, IC/II, and III/IV LGSOC, respectively [21]. Despite its slow growth, there is a poor sensitivity of LGSOC to chemotherapy. In this type of malignancy, there are mutations of genes involved in the mitogen-activated protein kinase (MAPK) pathway, such as $B R A F, K R A S, N R A S$, and $E R B B 2$, but occasionally there may be driver mutations of FFAR1, PIK3CA, USP9X, and EIF1AX linked to the AKT-mTOR pathway [22]. Moreover, RAD50 and NBS1 proteins are absent in LGSOC. Since estrogen and progesterone receptors are often expressed in LGSOC, hormone therapy can be a potential therapeutic alternative. Targeted therapy such as trametinib, a mitogen-activated protein kinase inhibitor, could represent a new standard of care treatment option for women with recurrent LGSOC. 
Ovarian clear cell carcinoma (OCCC) accounts for approximately 5\% of all ovarian carcinomas. When diagnosed at an earlier stage, it tends to have a good prognosis as surgery is often curative. In advanced stages, however, it is associated with a poor prognosis as it is often chemoresistant [23]. The 5-year overall survival rates are $81.7 \%, 69.0 \%$, and $22.3 \%$ for stage IA/IB, IC/II, and III/IV OCCC, respectively [21]. OCCC and clear-cell carcinoma of the kidneys share similar molecular pathways [24], and therefore targeted therapy aiming to inhibit angiogenesis, growth-factor signaling, and mTOR pathways might improve prognosis. Although preliminary clinical data focusing only on OCCC are limited, treatment with multikinase inhibitors (axitinib, sunitinib, sorafenib, and pazopanib), bevacizumab, temsirolimus, and everolimus may have anti-tumor activity in this particular malignancy. In OCCC, the most common somatic genetic alterations are loss of ARID1A, activation of PIK3CA, and mutations in PPP2R1A and KRAS [25]. Novel treatment strategies in the case of ARID1A mutated OCCC include the inhibition of the methyltransferase EZH2 and the administration of dasatinib and/or the HDAC6 inhibitor ACY1215. Since EGFR expression is detected in up to $60 \%$ of OCCC cases, EGFR inhibitors may also be effective. In addition, mTOR inhibitors may also be promising due to the high expression of mTOR in both earlyand advanced-stage OCCC [27].

Mucinous epithelial ovarian cancer (MOC) accounts for less than 5\% of EOCs. The 5year overall survival rates are $82.9 \%, 69.5 \%$, and $13.9 \%$ for stage IA/IB, IC/II, and III/IV OCCC, respectively [21]. While it is recommended to treat MOC with adjuvant carboplatin and paclitaxel, since HER2 is amplified or expressed in up to $19 \%$ of cases, trastuzumab and HER2- targeted therapies might be an effective treatment [23,26]. Molecular alterations in MOCs commonly involve KRAS, as well as mutations in CTNNB1 or APC gene, and high microsatellite instability (MSI-H) [28].

Sex-cord stromal tumors and malignant germ-cell tumors are very rare non-epithelial ovarian tumors, which overall account for only 6\% of all ovarian malignancies [36-39]. A common type of malignant sex-cord stromal tumor is granulosa cell tumor (GCT), of which there are the adult type and juvenile granulosa cell tumors. Granulosa cell tumors secrete progesterone and estrogen [29]. Testing for the FOXL2 c.402C > G (p.C134W) mutation is helpful in the diagnosis of adult-type tumors [30]. However, GATA4, SMAD, VEGF, PI3K/AKT, AMH, and TGF- $\beta$ are also involved in this type of cancer [31]. Granulosa cell tumors tend to have a slow progression and late recurrence. In the case of women with advanced-stage or recurrent granulosa cell tumors, traditional chemotherapy is limited in effectiveness [40]. Carboplatin and paclitaxel, a combination of bleomycin, etoposide, and cisplatin (BEP), and targeted therapies including VEGF inhibitors, tyrosine kinase inhibitors (TKIs), and hormonal treatment have been investigated as possible therapeutic options [23]. For Sertoli-Leydig cell tumors, DICER1 mutations seem to be a prognostic factor that is associated with a higher risk of relapse, especially in younger patients. In these tumors, adjuvant chemotherapy is recommended in stage IA disease particularly if there is poor differentiation or heterologous elements. BEP is commonly used, or else etoposide/cisplatin, carboplatin, and paclitaxel, cyclophosphamide/doxorubicin/cisplatin, or platinum agents alone. The 5-year overall survival rates are $90.7 \%$ and $76.2 \%$ for granulosa cell tumors and Sertoli-Leydig cell tumors, respectively [41].

Germ-cell tumors can be histologically classified as dysgerminoma, immature teratoma, yolk sac tumor, choriocarcinoma, embryonal carcinoma, mixed germ-cell tumor, malignant struma ovarii, gonadoblastoma, and teratoma with malignant transformation [18]. They are different from EOCs because they tend to be diagnosed in younger women, and due to their rapid tumor growth, they are usually symptomatic, thus leading to earlier diagnosis and a significantly better prognosis. Germ-cell tumors also have a different set of biomarkers such as alpha-fetoprotein (AFP), serum human chorionic gonadotropin (HCG), and lactate dehydrogenase (LDH) [42]. The most common mutations were found in KIT and KRAS, akin to testicular germ cell tumors [34]. Platinum-based regimens have led to a 5-year overall survival of over $90 \%$ for early-stage tumors and above $75 \%$ for advanced disease [37]. Adjuvant chemotherapy such as BEP is being used routinely. 
In the case of relapsed ovarian germ-cell tumors, treatment includes the use of paclitaxel, ifosfamide, and cisplatin, with extrapolation from current treatment used for testicular germ-cell tumors, and even using more complex regimens containing combinations of methotrexate, cisplatin, vincristine, and bleomycin, alternating with cyclophosphamide, etoposide and actinomycin D [36]. Furthermore, targeted therapies that have been investigated consist of trastuzumab (anti-HER2 monoclonal antibody, tyrosine kinase inhibitors (TKIs) (i.e., imatinib and sunitinib), and antiangiogenic agents such as thalidomide and bevacizumab [29].

In contrast to almost all other common OCs, the treatment of ROCs is challenging and often must be based on expert opinion, retrospective studies, or extrapolation from other tumor sites with similar histology. This leads to difficulty in developing effective guidelines for clinical practice.

\section{Availability of Cell Culture Models for Studying Common and Rare Ovarian Cancers}

Cancer and its corresponding healthy tissue cell lines are indispensable in vitro models for discovering new biomarkers and pre-clinical drug testing. Due to its extreme heterogeneity, there are many problems with using OCs cell lines as models for so many different OCs subtypes. One of the biggest problems is often misclassification of commonly used cell lines with respect to their tumor subtype [43]. Domcke et al., analyzed a panel of 47 commonly used OC cell lines and found significant genetic differences between them and HGSOC tumor tissue samples, while several less frequently used cell lines were found to be more genetically alike to the primary tumors [44]. A collection of 25 rigorously validated OC cell lines was reported to properly represent the OC subtypes from which they are derived [45]. Just recently, Barnes et al., used non-negative matrix factorization on transcriptomic data of 44 EOC cell lines to properly classify them into the five major histologically distinct subtypes (HGSOC, LGSOC, EC, OCCC, and MOC) [46]. All this pointed out an inevitable use of comprehensive omics techniques for proper classification of cell lines as models for tumor types which they represent. For instance, a genome-wide analysis of 45 OC cell lines, including some rare subtypes, revealed that these cell lines were largely representative of primary ovarian cancers. Analysis of mutation signatures demonstrated that serous, mucinous, and undifferentiated tumor subtypes showed the age-related signature, while clear cell and serous OCs also had a mismatch repair-associated signature. The most frequently mutated gene is TP53, followed by ARID1A, PIK3CA, SMAD4, KRAS, $A P C, C R E B B P$, and PPP2R1A. Frequent deletions include CDKN2A, CDKN2B, ERBB4, NF1, NF2, CDC73, EZH2 and STK11 [47]. This is somewhat consistent with the data available from The Cancer Genome Atlas (TCGA) project, which encompasses 489 HGSOC samples. The most frequently mutated gene in this dataset is also TP53, followed by NF1, BRCA1, BRCA2, RB1, and CDK12 [48]. TCGA analysis also revealed that somatic copy number abnormalities are common in HGSOC, resulting in frequent amplification of CCNE1, MYC, and MECOM genes, and deletions of PTEN, RB1, and NF1 [48]. Methylation analysis revealed increased promoter hypermethylation of AMT, CCL21, SPARCL1, $R A B 25$, and BRCA1 [48]. Considering the limitations of the TCGA subset, an omics-wide integrated analysis was performed on 96 primary invasive early-stage OCs divided into OCCC, EC, HGSOC, LGSOC, and MOC. Unique DNA methylation patterns were identified for each subtype, with OCCC showing the highest methylation, and HGSOC the lowest. MOC showed the highest average number of copy number alterations. RNA expression was able to classify the different histotypes, but the differences were more evident when using the DNA methylation heatmap [49].

One of the best and largest resources on cell lines is the Cellosaurus (https:/ / web. expasy.org/cellosaurus/) (accessed on 7 October 2021) [50]. Furthermore, the Cancer Cell Line Encyclopedia (https://sites.broadinstitute.org/ccle/) (accessed on 7 October 2021) [51] and the COSMIC Cell Line Project (https:/ / cancer.sanger.ac.uk/cell_lines) (accessed on 7 October 2021) [52] contain many different omics information obtained from cell lines. However, not all OC cell lines in those two databases are fully classified, so a 
combined survey of different databases and original publications is needed to discover to which OC subtype a cell line of interest belongs.

\section{Long Non-Coding RNAs: Classification and Mechanisms of Action}

Non-coding RNAs (ncRNAs) are a large class of RNA molecules that are translated but do not encode proteins. This class includes a wide range of different RNA molecules, which can be broadly classified into infrastructural ncRNAs and regulatory ncRNAs. Infrastructural ncRNAs include transfer RNAs (tRNAs), ribosomal RNAs (rRNAs), and small nuclear RNAs (snRNAs) and their functions are well-known and have been examined in detail [53]. Regulatory ncRNAs include molecules such as small nucleolar RNAs (snoRNAs), microRNAs (miRNAs), small interfering RNAs (siRNAs), P-element-induced wimpy testis interacting (PIWI) RNAs (piRNAs), and long non-coding RNAs (lncRNAs). SnoRNAs, miRNAs, and piRNAs are collectively named small non-coding RNAs (sncRNAs).

LncRNA molecules are transcribed by RNA Polymerase II and processed in a way that resembles mRNA processing, as they are often $5^{\prime}$ capped, $3^{\prime}$ polyadenylated, and spliced similarly to mRNAs [54]. It has been demonstrated that $98 \%$ of lncRNAs are spliced [55], while only $40 \%$ of lncRNA transcripts are non-polyadenylated [56,57]. Furthermore, lncRNAs show a bias toward two-exon transcripts, with slightly longer exons and longer introns than protein-coding genes which are often alternatively spliced. Their level of expression is generally lower than that of protein-coding genes and is more tissue-specific [55,58,59].

Biogenesis of lncRNAs is based on their location in respect to protein-coding genes, and lncRNAs can thus be classified into four categories: (1) long intergenic non-coding RNAs (lincRNAs), transcribed intergenically from both strands; (2) sense intronic transcripts, located within introns of coding genes without intersecting with exons; (3) sense overlapping transcripts, which overlap with the exons of coding genes on the same strand; and (4) antisense RNAs, which are located within the exons and introns of protein-coding genes but on the opposite strand (so-called natural antisense transcripts or NATs) (Figure 1) [60-63]. The majority of lncRNA loci are located in intergenic regions [55]. A detailed explanation of lncRNA biogenesis can be found in [64].

A

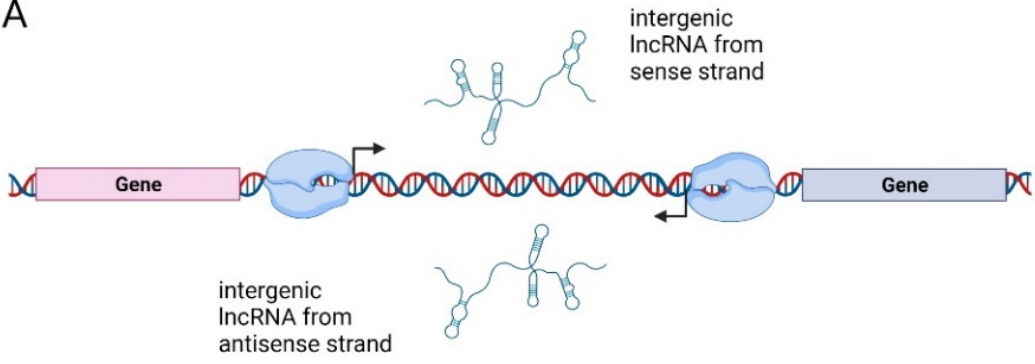

B

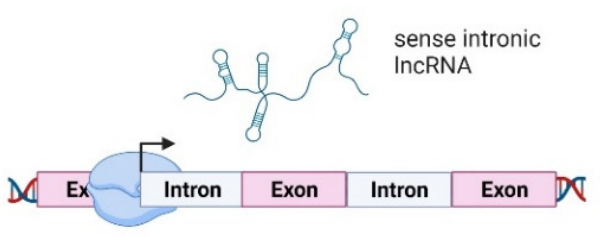

C

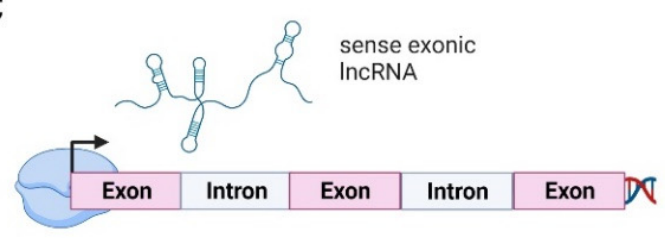

D

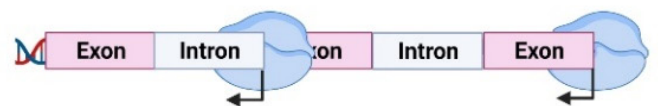

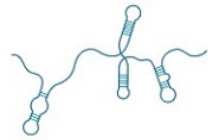

intron-overlapped antisense IncRNA

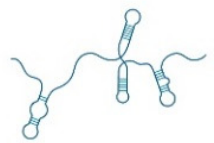

exon-overlapped antisense IncRNA

Figure 1. Categories of lncRNAs based on their location in respect to protein-coding genes. (A) Long intergenic non-coding RNAs (lincRNA) are transcribed intergenically from both strands. (B) Sense intronic transcripts are located within introns of coding genes without intersecting with exons. (C) Sense overlapping transcripts overlap with the exons of coding genes on the same strand. (D) Antisense RNAs are located within the exons and introns of protein-coding genes but on the opposite strand. Created with BioRender.com. 
Mutations and genomic rearrangements can affect the expression of lncRNA in the same way as they affect the protein-coding genes and can contribute to tumorigenesis. Aznaourova et al., have summarized a list of lncRNAs involved in various human diseases, including gynecological cancers [65]. Regulation of tumor progression by lncRNA can occur through modification of several mechanisms: the epigenetic regulation of genes (chromatin remodeling, histone modification, DNA methylation), the transcriptional regulation of genes (cis-regulation of nearby genes or trans-regulation of distant genes), and post-transcriptional regulation of gene expression (alternative splicing of pre-mRNA, stabilization of mRNA, and translation and stabilization of proteins) [7].

Initial systematic large screening of lncRNA genes, using genome-wide chromatinstate maps by immunoprecipitation, identified over a thousand highly conserved lncRNAs [66]. The current estimate of the number of genes encoding lncRNA according to the GENCODE and FANTOM projects is between 17,957 and 27,919 genes [67]. Their functions are classified as either (1) RNA-based, where lncRNA interacts with DNA, RNA, or proteins, (2) gene-regulatory, where lncRNA modifies the activity of regulatory elements, or (3) transcription-based, where the process of transcription influences gene activity [67]. They can function as signals, decoys, guides, or scaffolds (Figure 2) [7].

A
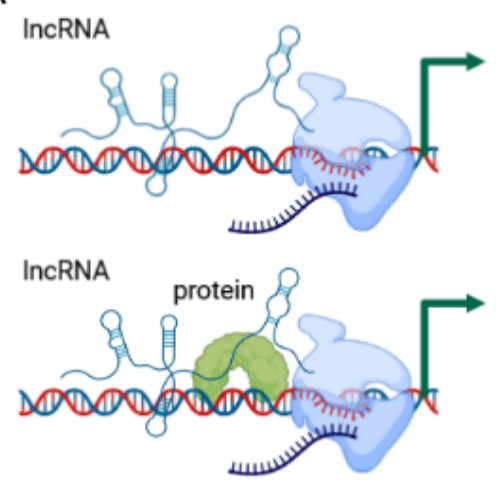

B

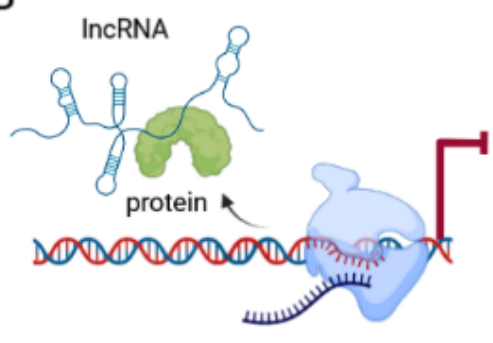

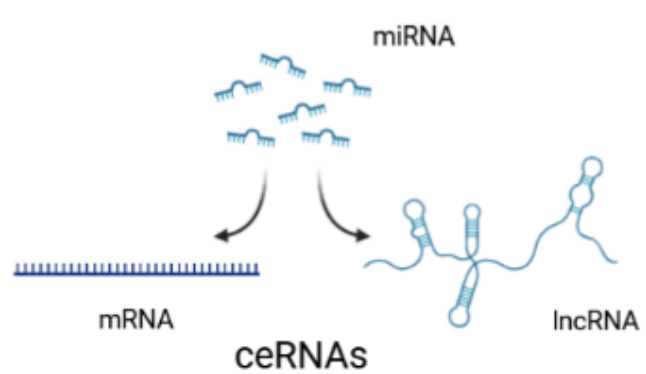

C

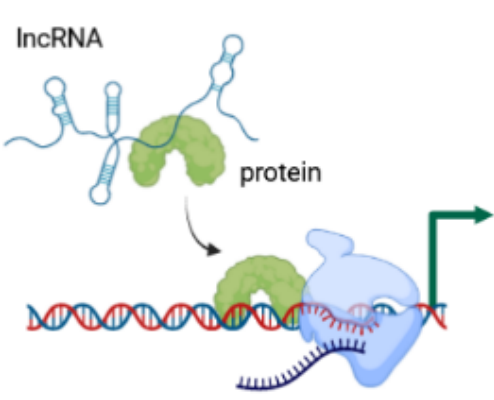

D

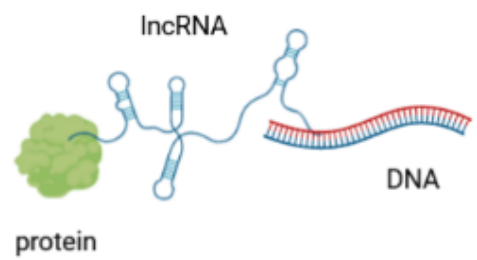

Figure 2. Functional roles of lncRNAs. (A) As signal molecules, lncRNAs act either alone or in combination with proteins like transcription factors to mediate the transcription of downstream genes; (B) As decoys, lncRNAs either bind to functional proteins to block their activity or compete with mRNAs for binding to miRNAs to block their inhibitory effects on mRNAs; (C) As guides, lncRNAs carry and locate functional proteins in the target area to perform their functions; (D) As scaffolds, lncRNAs guide different types of macromolecules to assemble complexes and facilitate their interactions. Created with BioRender.com.

LncRNAs are considered to signal molecules when they regulate the transcription of target genes. In this context, lncRNA can exert this effect alone, or in combination with transcription factors. Their expression is triggered by specific conditions, and they in turn trigger specific responses to those conditions. The best-known example of this type of regulation is the lncRNA XIST, which is involved in X-chromosome inactivation by direct interaction with the chromatin [68]. Other examples include lncRNA HOTAIR, which is 
transcribed from the homeobox transcription factor cluster (HOX) in tightly controlled conditions; PANDAR, which is induced by DNA damage; LINC-ROR, which is associated with reprogramming to induced pluripotent stem cells; and COLDAIR, which is induced by cold [69].

When acting as decoys, they usually block specific molecular pathways by binding to a specific protein or RNA and impairing its function. This is the most common type of regulation that lncRNAs exert on their targets. The targets are most often miRNA molecules, and lncRNAs antagonize the miRNA they target by sequestering the miRNA away from their intended mRNA targets [69]. Competing endogenous RNAs (ceRNAs) or "molecular sponges" act as competitive inhibitors which block the activity of the target mRNAs. Most often this mechanism acts to "sponge" various miRNA molecules, thereby removing them from their intended targets and suppressing their effect [70].

Guide lncRNAs direct the localization of ribonucleoprotein complexes to specific targets. This effect can be achieved in cis, when they affect neighboring genes, or in trans when the effect is on distant genes. These effects are mediated through changes in the structure of chromatin. Regulation in cis involves specific interaction between the lncRNA and chromatin at its promoter, leading to accumulation of proteins involved in histone 3 lysine 9 (H3K9) methylation and gene silencing. Regulation in trans often targets proteins of the Polycomb Repressive Complex (PRC) and changes their localization, activity, and occupancy, leading to changes in chromatin structure in trans. HOTAIR is one such lncRNA, often found overexpressed in tumors and associated with cancer metastases [69].

When acting as scaffolds, they facilitate the interaction of different molecules and proteins. CDKN2B-AS1, a lncRNA located in the INK4b/ARF/INK4a locus, recruits multiple chromatin-modifying proteins and thereby modulates transcriptional activity of the locus [69]. It is important to emphasize that lncRNAs employ more than one mechanism of action to exert their effects, so one function does not necessarily exclude all others. There are potentially other yet undescribed mechanisms by which lncRNAs can affect gene and protein expression and function.

Even though lncRNAs were originally defined as RNA which do not encode proteins, recent reports suggest that some lncRNAs contain open reading frames (ORF) and may encode peptides [71]. These peptides are involved in various signaling processes, e.g., mTOR signaling, regulation of $\mathrm{Ca}^{2+}$-ATPase, mRNA decay, and mitochondrial activity. They can also be involved in metabolic reprogramming of several cancers, such as colon, liver, esophageal, and breast cancer, and melanoma [71]. Furthermore, lncRNAs can also encode miRNAs, as exemplified by miR-675 which is transcribed from exon 1 of H19 [72].

\section{Intracellular and Extracellular Compartmentalization of lncRNAs}

LncRNAs can be found in different cellular compartments, from the nucleus to cytoplasm and mitochondria, and even exported from the cell via exosomes. About $30 \%$ of lncRNAs are located in the nucleus, where they can interact with transcription factors, chromatin complexes, and heterogenous ribonucleoprotein complexes [73]. Within the cytoplasmic compartment, lncRNAs can be found in many structures and organelles. LncRNAs in ribosomes are most often associated with nonproductive initiation of translation, but small peptides may be produced from open reading frames in individual lncRNA. Additionally, lncRNAs in the ribosome may act as regulators of translation [74]. So far, several lncRNAs that are transcribed from the mitochondrial genome, and about 20 nuclear-encoded lncRNAs that affect mitochondrial biology have been described [75]. These include some ubiquitous lncRNAs that are involved in many oncogenic processes, such as SAMMSON, HOTAIR, H19, HOTTIP, and MEG3, but also some specific ones, like CEROX1 (cytoplasmic endogenous regulator of oxidative phosphorylation 1), which affects the process of oxidative phosphorylation. Mitochondria-encoded lncRNAs are either antisense mitochondrial transcripts, like $\ln c N D 5, \ln N N D 6, \ln c C Y B$, and MDL1AS; chimeric mitochondrial transcripts, like $A S n c m t R N A-1$ and $A S n c m t R N A-2$; or putative mitochondrial DNA-encoded lncRNAs, like LIPCAR [75]. 
Exosomes are bi-layered membrane vesicles secreted from the cells, 30-150 nm in diameter, which can contain a wide range of molecules usually found within the cells. They are generated by the budding of the endosomal membrane. LncRNAs are packed inside exosomes whereby they interact with RNA-binding proteins through specific motifs. Exosomes are used in cell-to-cell communication, and whatever is packed inside an exosome may be delivered to a receiving cell and trigger a specific molecular response in that cell. In the case of tumor-derived exosomes, these responses range from tumor growth, invasion, and metastasis to angiogenesis and reprogramming of the tumor microenvironment. Furthermore, several lncRNAs (UCA1, FAM225A, RAMP2-AS1, POU3F3, HOTAIR, CCAT2) have been identified that affect the endothelial cells of blood vessels and stimulate angiogenesis [76]. The cancer-associated fibroblasts-derived exosomes were shown to carry lncRNA H19, which is highly expressed in tumor stroma in comparison to tumor tissue. This lncRNA promotes stemness and chemoresistance of cancer cells and increases the frequency of tumor-initiating cells [77].

\section{The Role of lncRNAs in Various Biological Processes Related to Ovarian Carcinogenesis}

Each hallmark of cancer can be modulated by lncRNA activity, thus leading to increased proliferation, viability, growth suppression, motility, immortality, and angiogenesis [78]. It has been debated whether lncRNAs can act as initiators of tumorigenesis, or if they are dysregulated as a consequence of tumorigenesis. The Cancer LncRNA Census contains a compilation of 122 GENCODE lncRNAs associated with the initiation of tumorigenesis, some (63.1\%) acting as oncogenes, some (28.7\%) as tumor suppressors, and some $(8.2 \%)$ with evidence of both activities depending on tumor type. LncRNAs HOTAIR, MALAT1, MEG3, and H19 are associated with a large number of cancer types [79]. The same study identified tumor-causing mutations in several lncRNAs, supporting their role in tumor initiation [79]. A recent literature survey of Salamini-Montemurri et al., has identified 215 lncRNAs being involved in OCs, of which for 157 there is experimental proof [8]. Apart from initiation, lncRNAs have been associated with many biological processes associated with metastasis [80], such as the immune response [73], radiation response [81], epithelial to mesenchymal transition (EMT) and stemness [82], cell-to-cell communication, and regulation of the microenvironment in which cells reside [77].

It is generally said that in the context of OC, there is proof that lncRNAs are involved in all the hallmarks of cancer except 'genomic stability and mutation' and 'enabling replicative immortality' [8]. Several lncRNAs showed influence on the size and weight of ovarian tumors in vivo, such as AB073614 [83], EPB41L4A-AS2 [84], GAS5 [85], LINC00565 [86], TINCR [87] and TPT1-AS1 [88]. Loss of cell cycle control, related to proliferative signal maintenance and evasion of growth suppressors, is in OC associated with lncRNAs MNX1-AS1 [89], SPRY4-IT [90], KB-1471A8.2 [91], and CASC15 [92]. Avoidance of cell death which causes cell immortalization has mostly been studied in the context of apoptosis. It was shown that lncRNA $L N C R N A-A T B$ [93] can regulate apoptosis in OC. Also, GAS5 can trigger a highly inflammatory type of programmed cell death called pyroptosis [94], while some lncRNAs can either induce (MEG3 [95] and MALAT1 [96]) or inhibit (HOTAIR [97], HULC [98] and RP11-135L22.1 [99]) autophagy in OC. Some lncRNAs can control cancer cell metabolism by regulating key enzymes in metabolic pathways, mainly stimulating glycolysis (the Warburg effect) [100]. For instance, it was shown in OC that lncRNAs LINC00504 [101], NRCP [102], LINC00092 [103], and H19 [104] can activate different enzymes in the glycolysis pathway from glucose to pyruvate. It has been shown that MALAT1 promotes angiogenesis in OC by inducing the expression of $V E G F$ and FGF [105], while DANCR [106] and HNF1A-AS1 [107] can promote it by inducing VEGF and SEMA4D expression.

LncRNAs play a role in the regulation of immune response, where they are involved in several mechanisms of action. A major role is antisense silencing associated with DICER and molecular sponge function for reducing the regulatory effects of miRNAs [73]. Many stages of the immune response can be targeted and regulated by lncRNAs. 
Tumor antigen release, more specifically, the expression of chaperone calreticulin, can be inhibited by lncRNA expressed from the RB1 promoter (RB1-DT). Antigen presentation can be affected by the specific reduction of the abundance of antigen-presenting cells (lincRNA LINC01139) or by the regulation of pro-inflammatory cytokines. EGILA can affect the differentiation of $\mathrm{T}$ lymphocytes, thereby affecting immune cell priming and activation. LncRNAs can also affect immune cell migration and infiltration, and affect recognition and attack of cancer cells [108]. HOTTIP was cited as the only lncRNA associated with the avoidance of immune surveillance by increasing IL6 expression in ovarian tumor cells, which triggers PD-L1 expression through the STAT3 pathway in neutrophils [109]. Therefore, targeting specific lncRNAs or modifying their activity to boost the immune response or increase recognition of tumor cells may be a potential therapeutic approach in ROCs.

Resistance to radiation can be modulated positively and negatively by the lncRNAs. Some lncRNAs, such as GAS5, increase the radiosensitivity of cancer cells through their sponging mechanisms. In contrast, other lncRNAs, such as HOTAIR or TUG1, can increase radioresistance by sponging specific miRNAs. Expression of lncRNAs can also be used as biomarkers of radiation damage, as IncRNA TP53COR1, TUG1 and MEG3 have been found to be upregulated after radiation damage by multiple studies [81]. Increasing the radiation sensitivity of tumor cells or increasing radiation resistance in healthy tissues by targeting specific lncRNA targets could be a promising approach for the treatment of various cancers, including ROCs.

EMT is a reversible process during which epithelial cells acquire mesenchymal characteristics, including reduction of cell-cell contacts, changes in cell morphology, and increase of migratory capability. This transition is considered one of the crucial steps during tumor invasion and metastasis. The process is reversible, and under the right conditions, the cells can transition back from mesenchymal to the epithelial phenotype, resulting in mesenchymal to epithelial transition (MET). EMT process is regulated by specific transcription factors such as SNAIL, SLUG, TWIST1, TWIST2, ZEB1, and ZEB2 [110]. Cancer stem cells (CSC) are a subpopulation of tumor cells with the capacity for self-renewal, asymmetric division, and multipotency. This stemness phenotype is often acquired through the EMT process and regulated by transcription factors SOX2, OCT4, NANOG, KLF4, and LIN-28. Many of these EMT and CSC regulators can be controlled by lncRNA such as HOTAIR, H19, MALAT1, LINC-ROR, HOTTIP, NEAT1, LNCRNA-ATB, and others [82].

Cell-to-cell communication and the microenvironment are important factors during tumor progression and metastasis. Tumor cells interact with their environment and various cell types in their surroundings. The most abundant and relevant cell types in this microenvironment are the cancer-associated fibroblasts (CAF), which respond to the cytokines produced by the tumor to support tumor growth and dissemination. Many lncRNAs are upregulated in the CAF compared to normal fibroblasts, such as MALAT1, NEAT1, H19, GAS5, and MEG3 [77,111]. The communication also goes in the opposite direction, from tumor cells to fibroblasts, reprogramming them into CAF-like cells [77]. Interrupting this cell-to-cell communication between tumor and stromal cells through lncRNAs is also a promising approach to tumor treatment, as the microenvironment plays a major role in the ability of tumors to grow, progress, and ultimately metastasize.

Post-translational modifications (PTMs) of proteins are involved in several biological phenomena including signaling processes that occur at different stages of tumor development $[112,113]$. Although the mechanism of action is not fully discovered, change in the PTMs affects protein activity, stability, protein-protein, and protein-nucleic acid interactions.

LncRNAs interfere with PTMs in the cytoplasm [114]. They may downregulate the PTMs by interacting with enzymes involved in PTMs and/or blocking the modification sites. The size of PTMs and associated proteoforms in biological systems are too large and there is no model system that shows the dynamic interactions in diseases. However, IncRNA-interacting genes obtained from bioinformatical analyses can be used to assess the potential IncRNA-PTMs relationship in OC. 
Histones are subjected to several PTMs including methylation, acetylation, phosphorylation, and ubiquitination [115]. It has been previously shown that methyl-CpG-binding domain protein 1 (MBD1) interacts with $H 19$ through repressing the methylated regions. It also affects the adjacent insulin-like growth factor 2 gene and associated proteins [114]. Both alterations in MBD1 [116] and insulin-like growth factors are linked to OC. Histone acetylation is another key chromatin modification causing epigenetic variation that is implicated in OC pathogenesis $[117,118]$. LncRNAs can change this process either by interrupting the histone acetylation process, such as LNCPRESS1 binding to SIRT6 and preventing its binding to histones [119], or by acting as scaffolds regulating histone acetylation and methylation, such as GClnc1 which acts as a scaffold for WDR5, and KAT2A proteins [120].

It is well-known that phosphorylation of proteins is one of the most common mechanisms that regulate protein activity, and phosphorylation is often dysregulated in cancer. AKT and mTOR phosphorylation have been detected as potential biomarkers for OC and tumor growth [121]. LncRNA-AKT interactions were experimentally shown in lung cancer [122] which might be a sign for similar connections for other cancers including ovarian.

The majority of the proteins are glycosylated and glycosylation plays a crucial role in cancer biology [122] and serves both as a diagnostic and prognostic biomarker for OC [122-125]. Protein-specific glycosylation studies have discovered changes in Immunoglobulin G (IgG), haptoglobin beta-chain, alpha1-acid glycoprotein, and alpha1antichymotrypsin glycosylation in OC [126]. Although the role of IncRNAs has not been completely explored in OC, a link between lincRNAs and N-Glycosylation of IgG has been detected [127].

Both bioinformatical and experimental studies have discovered that lncRNAs prompt PTMs at different levels. The outcomes need to be further investigated to unravel the possible mechanisms leading to accurate diagnosis and effective treatments.

LncRNAs, primarily through their crosstalk with miRNAs, regulate the osteogenic differentiation of mesenchymal stem cells (MSCs), a population of stromal cells in the bone marrow, and other anatomical regions such as adipose tissue and apical papilla of the tooth [128]. MSCs are capable of self-renewal and differentiation into multiple cell lineages, of which osteoblasts are important for bone development, homeostasis, and regeneration [129]. Their differentiation is mediated by several signaling pathways of which TGF- $\beta / \mathrm{BMP}$ and $\mathrm{WNT} / \beta$-catenin pathways are central [130]. Interestingly, several lncRNAs which were found to be differentially expressed in OCs, such as H19, NEAT1, MALAT1, HOTAIR, or XIST, participate in this cellular process [131]. Although osteogenic differentiation is primarily associated with the development of osteosarcoma [132], MSCs could be recruited to the tumor microenvironment and can both restrict [133] and promote solid tumor growth [134]. In OCs, carcinoma-associated MSCs have been identified in ovarian tumor tissue samples and it was proven that they can regulate ovarian cancer stem cells proliferation and tumorigenesis through altered production of BMP [135]. It was also shown that umbilical cord MSCs inhibited the growth of EC cell line TOV-112D [136], while bone marrow MSCs reduced the growth rate of cisplatin-resistant EC SKOV3 cells [137]. $\mathrm{Bu}$ et al. showed that also endometrial MSCs derived from human menstrual blood can attenuate tumor growth of EC cell line SKOV3 and postulated that observed intrinsic antitumor properties of adult MSCs could be utilized for developing an MSC-based therapy for treating OCs [138].

\section{LncRNAs Associated with Common and Rare Ovarian Cancers}

TCGA data has been used to analyze lncRNA in different tumor types, but OC has not been analyzed in more detail because the TCGA database lacks the appropriate healthy tissue controls for HGSOC samples, thus making the differential expression analysis impossible for OC $[139,140]$. However, somatic copy number alterations are frequent in OC, and lncRNA BCAL8 has been found amplified in breast cancer and associated with poor clinical 
outcomes of OC [139]. HGSOC can be divided into four distinct subtypes: immunoreactive, characterized by CXCL11, CXCL10, and CXCR3 expression; differentiated, characterized by MUC16 and MUC1 expression; proliferative, characterized by HMGA2, SOX11, MCM2, and PCNA overexpression and MUC1 and MUC16 downregulation; and mesenchymal, characterized by high expression of HOX genes, FAP, ANGPTL2 and ANGPTL11 [48]. Mesenchymal subtypes often show upregulation of MIAT (also known as gomafu in humans), proliferative types show downregulation of NEAT1 and UCA1, while serous subtypes show frequent amplification of OVAL [140].

Several lncRNAs have been found to have an effect in a wide range of human cancers, including many gynecological cancers. In OC, a specific signature of six lncRNA has been identified by a bioinformatical analysis. This signature associates RUNX1-IT1, MALAT1, H19, HOTAIRM1, LOC100190986, and AL132709.8 IncRNAs [141]. Of these, MALAT1 and $H 19$ have been extensively studied in OC, along with several other lncRNAs: HOTAIR, NEAT1, XIST, MEG3, and UCA1. Most extensively analyzed lncRNAs in OC have been listed in Table 2, and the lncRNAs more specific for ROCs are summarized in Table 3.

\subsection{H19}

A locus for the $H 19$ imprinted maternally expressed transcript produces a $2.3 \mathrm{~kb}$ long RNA transcript, which is abundantly expressed during embryonic development and downregulated after birth. It is a paternally imprinted gene, but imprinting loss, and subsequent overexpression, have been associated with ovarian tumors [142,143]. Knockdown of this lncRNA promotes G2/M cell cycle arrest, induces apoptosis of OC cells, and inhibits cell growth [143]. H19 can act as a competing endogenous RNA of miR-370-3p, resulting in the promotion of TGFB1-induced EMT [144], and as an inhibitor of a tumor-suppressor miRNA let-7, resulting in increased tumor cell migration and invasion [145]. H19 is elevated in OC cells resistant to cisplatin [146]. Its downregulation leads to increased sensitivity to cisplatin $[147,148]$. Polymorphisms in the $H 19$ locus are associated with platinum-based chemotherapeutic response [149]. H19 can also affect cancer cell metabolism, through the sponging effect of miR-324-5p, which regulates PKM2, a major contributor to the Warburg effect [104]. Although most of these studies were performed on serous epithelial ovarian cancer cell lines, the role of $H 19$ has also been examined in some ROCs. H19-overexpressing choriocarcinoma cells were found to be more tumorigenic in vivo, even though there was no difference in their clonogenicity in the in vitro assays. There is a selection of cells expressing high levels of $\mathrm{H} 19$ during the microevolution of tumor progression, which suggests that this lncRNA does not act as a tumor-suppressor [150]. Loss of $H 19$ imprinting has also been demonstrated in pediatric germ cell tumors, and it may reflect the origin of these tumors in different stages of germ cell development [151-153]. Benign ovarian teratomas show a varying degree of $H 19$ hypomethylation, and DNA prepared from cultured teratoma cells shows extreme hypomethylation of the H19 locus [154]. Ovarian granulosa cell tumor cell line KGN has been used to demonstrate that lncRNA H19 binds to miR-19b, resulting in upregulation of CTFG, increase in cell proliferation, $d$ reduction in the rate of apoptosis in these cells [155].

\subsection{HOTAIR}

HOX transcript antisense RNA (HOTAIR) has shown some potential as a diagnostic and predictive biomarker. This lncRNA acts as a molecular scaffold and binds the Polycomb Repressive Complex 2 (PRC2) on its $5^{\prime}$ domain and the lysine-specific histone demethylase 1A (LSD1)/CoREST/REST complex on its $3^{\prime}$ domain, bringing them in close proximity and methylating lysine 27 and demethylating lysine 4 of histone $\mathrm{H} 3$, leading to consequent gene silencing $[156,157]$. Expression of HOTAIR promotes proliferation, stemness, and epithelialto-mesenchymal transition of OC cells [158-160]. The transcription of HOTAIR is induced by estrogen, making it a relevant lncRNA in the context of gynecological cancers [161]. It has been associated with poor prognosis and tumor metastasis in epithelial ovarian cancer and cervical cancer [162-164]. Its prognostic value has been evaluated by a meta-analysis 
in four estrogen-dependent tumor types (breast, ovarian, cervical, and endometrial), and it may be a predictor of poor prognosis [165]. Specific genetic variants of HOTAIR may in some populations affect OC susceptibility $[166,167]$. HOTAIR expression is also associated with chemoresistance in clinical samples and in vitro models, and its knockdown can lead to increased sensitivity to cisplatin and carboplatin both in vitro and on a mouse xenograft model $[97,159,168,169]$. A peptide nucleic acid (PNA) designed to specifically block the activity of HOTAIR has been successful in reducing ovarian tumor growth in vitro and in vivo, and improved survival of xenograft mice, and has been suggested as a potential new therapeutic approach for the treatment of OC [170]. The potential use of this lncRNA as a biomarker has led to the development of various methods for detection of this lncRNA from samples derived from patients with OC, primarily plasma [171,172].

\subsection{MALAT1/NEAT2}

Metastasis-associated lung adenocarcinoma transcript 1 (MALAT1), also known as nuclear-enriched abundant transcript 2 (NEAT2), is another lncRNA significantly overexpressed in various cancers $[173,174]$, and has been extensively studied in OC. A metaanalysis revealed that MALAT1 could be a novel biomarker in various cancers, including ovarian [175]. It can be detected in the plasma, and it has been suggested as a potentially useful marker for OC metastases [176]. Metastatic EOC cells show increased expression of $M A L A T 1$ and increased secretion through their exosomes, and this activates angiogenesisrelated genes in the endothelial cells [105]. MALAT1 is highly overexpressed in OC and is associated with the FIGO stage. Its overexpression leads to increased cell proliferation, migration, and invasion $[177,178]$. It can act through sponging several different miRNA molecules, all resulting in increased proliferation and survival of cancer cells: miR22 [179], miR-506 [180], miR-200c [181], miR-143-3p [182], miR-200a [96], miR-211 [183], miR-503-5p [184]. MALAT1 has also been found to downregulate RBFOX2, which leads to the alternative splicing of the KIF1B and production of the pro-apoptotic long isoform of KIF1B, ultimately resulting in inhibition of anoikis [185].

Other signaling pathways which are directly or indirectly affected by MALAT1 include the PI3K-AKT pathway [186] and the ERK/MAPK pathway [187]. MALAT1 has also been implicated in drug resistance of $\mathrm{OC}$, as it was found upregulated in cisplatin-resistant OC cells, where it sponges miR-1271-5p, leading to upregulation of E2F5 and increased proliferation, migration, and invasion [188]. MALAT1 is also upregulated in OC spheroids when compared to their adherent counterparts, suggesting a role of MALAT1 in cancer cell stemness [189]. Knockdown of MALAT1 can restore chemosensitivity of OC to cisplatin through the inhibition of the NOTCH1 signaling pathway [190]. Apart from the effects of MALAT1 investigated in OC in general, some ROCs have also been investigated. Experiments on the KGN cell line demonstrated that MALAT1 is upregulated in these cells and involved in the maintenance of proliferation and viability as well as inhibition of autophagy [191]. MALAT1 knockdown induces upregulation of p21, p53, p-JNK, and p-ERK1/2, and downregulation of CDK2, cyclin D1, and p-P38 MAPK protein levels [187]. In choriocarcinoma MALAT1 binds to miR-218, leading to upregulation of FBXV8 oncogene and cell proliferation [192]. In KGN cells knockdown of MALAT1 results in inhibition of the ERK/MAPK pathway leading to the inhibition of cell proliferation and cell cycle progression [187].

\subsection{MEG3}

Maternally expressed 3 (MEG3) lncRNA has been reported as a tumor suppressor. Its major role is in the positive regulation of the tumor suppressor gene TP53 [193]. MEG3 is downregulated in many cancers, such as breast [194], cervical [195], gastric [196], lung [197], and EOC [198]. Downregulation in EOC is achieved through hypermethylation of the $M E G 3$ promoter, as treatment with demethylating agent 5-aza-2-deoxycytidine increases $M E G 3$ expression. Increased expression of MEG3 suppresses proliferation and growth and induces apoptosis, and suppresses tumorigenesis in vivo [95,198]. Upregulation of MEG3 
induces expression of PTEN and $L A M A 4$, leading to inhibition of cell proliferation, cell cycle arrest, and induction of apoptosis [199,200]. On the other hand, high expression of MEG3 is associated with better progression-free survival and overall survival in HGSOC, even though the same authors demonstrated that MEG3 is downregulated in HGSOC cell lines compared to the normal fallopian tube and ovarian cell lines, and upregulation of MEG3 in HGSOC cells leads to inhibition of tumor growth in vitro and in vivo [201]. It can bind directly to ATG3 mRNA and protect it from actinomycin D-induced degradation [95]. $M E G 3$ is one of the three signature lncRNA that can be used to predict cisplatin resistance in OC. Upregulated PVT1 and downregulated TUG1 and MEG3 have high sensitivity and specificity in predicting chemoresistance and are negatively associated with OS and progression-free survival [202]. Sensitivity to cisplatin can be restored with curcumin treatment, as it leads to demethylation of the MEG3 promoter, sponging of miR-214 by MEG3, and consequent reduction of drug resistance [203]. MEG3 expression can be negatively regulated by another lncRNA: $A G A P 2-A S 1$, which is upregulated in OC and participates in cancer cell proliferation [204].

\subsection{NEAT1}

Nuclear Paraspeckle Assembly Transcript 1 (NEAT1) is another lncRNA that is overexpressed in various cancers, including OC. NEAT1 is upregulated in OC, positively correlated with FIGO stage, tumor grade, and distant metastasis. NEAT1 expression level is an independent factor in predicting the overall survival of OC patients [205]. A meta-analysis of 1354 patients from 11 studies revealed that NEAT1 expression is indeed significantly associated with poor overall survival, larger tumor size, lymph node metastasis, distant metastasis, TNM-stage, poor differentiation, and invasion depth [206]. Based on all this, NEAT1 has been proposed as a prognostic biomarker in breast, ovarian, cervical, endometrial, and vulvar cancers [207]. It interacts with several miRNAs: miR-34a-5p [208], miR-124-3p [209], miR-382-3p [210], miR-506 [211], miR-1321 [212], miR4500 [213] and miR-365 [214]. NEAT1 is also involved in the development of resistance. In the platinum-resistant OC cells, NEAT1 binds miR-770-5p, leading to upregulation of PARP1. Knockdown of NEAT1 expression results in a reduction in xenograft tumor growth as well as increases sensitivity to cisplatin [215]. In the case of paclitaxel (PTX) resistance, NEAT1 is upregulated in PTX-resistant OC tissues and cells and binds to miR-194. NEAT1 knockdown enhanced the sensitivity of cells to PTX through the miR-194/ZEB1 axis [216]. The potential of NEAT1 as a possible diagnostic marker has been proposed in several cancers, such as prostate [217] and breast [218]. For EOC, a serum biomarker panel that combines gene and protein expression was proposed as a method for early detection of EOC, and NEAT1 is one of the proposed lncRNA in this panel [219].

\subsection{UCA1}

Urothelial cancer associated 1 (UCA1) is an oncogenic lncRNA found to be upregulated in many solid tumors. A meta-analysis revealed that upregulation of UCA1 is negatively associated with overall survival and progression-free survival in many cancers, including OC [220]. UCA1 acts as a sponge for miR-485-5p, which in turn upregulates the levels of MMP14, and this upregulation of MMP14 is an important factor in OC metastasis [221,222]. It can also bind directly to AMOT, a known regulator of YAP, and promote activation of YAP and subsequent transcription of target genes [223]. It has been suggested as a potential new biomarker and therapeutic target of OC, especially in the context of drug resistance where it may serve as an indicator of response to therapy [224,225]. For example, UCA1 expression induces cisplatin resistance in OC cell lines. This could be mediated through the upregulation of SRPK1 [226] or the miR-143/FOSL2 axis [227]. Paclitaxel resistance has also been associated with UCA1 expression, by regulating the miR-654-5p/SIK2 axis [228] and/or the miR-129/ABCB1 axis [229]. 


\begin{abstract}
6.7. XIST
$\mathrm{X}$ inactive specific transcript (XIST) regulates $\mathrm{X}$-chromosome inactivation, by acting as a scaffold for repressive epigenetic factors, and as many as 30 different RNA-binding proteins are predicted to bind with XIST. XIST RNA contains structured regions, or Xist motifs, which are crucial for its function. Of these, the A-repeat (RepA) folds into a stemloop structure and is required for gene silencing [230]. A meta-analysis has demonstrated that XIST is associated with poor overall survival, larger tumor size, increased distant metastases, and advanced tumor stage in a range of cancers [231]. In OC, there are conflicting results. XIST has been found to be downregulated and correlated to better prognosis in OC in one study [232], while another study shows that XIST was upregulated in OC tissues and cell lines and is suggested as an independent predictor of prognosis for OC patients [233]. Studies regarding the role of XIST in OC are also contradictory-some claim upregulation of XIST leads to stimulation and increased proliferation of OC cells, while others claim it suppresses OC proliferation and tumor growth [233-237].
\end{abstract}

Table 2. The lncRNAs frequently involved in OCs and their mechanisms of action. OC type includes rare OC types (GCT-granulosa cell tumor) and common OC types (HGSOC-high-grade serous ovarian carcinoma, EOC-epithelial ovarian cancer, EC-endometrioid carcinoma), while the abbreviation OC refers to papers that did not define specific OC subtypes, and OCSC refers to ovarian cancer stem cells.

\begin{tabular}{|c|c|c|c|c|c|c|}
\hline $\operatorname{lncRNA}$ & Target & OC Type & $\begin{array}{l}\text { Mode of } \\
\text { Action }\end{array}$ & Effect & Role & Reference \\
\hline \multirow{4}{*}{ H19 } & $\operatorname{miR}-370-3 p$ & EC, HGSOC & ceRNA & \multirow{2}{*}{$\begin{array}{c}\text { Promotes TGFB1-Induced EMT } \\
\text { Promotes Warburg Effect through } \\
\text { PKM2 }\end{array}$} & Oncogene & [144] \\
\hline & miR-324-5p & $\mathrm{EC}$ & ceRNA & & Oncogene & [104] \\
\hline & miR-19b & GCT & ceRNA & $\begin{array}{c}\text { Increased Expression of CTGF, } \\
\text { Resulting in Cell Proliferation and } \\
\text { Reduced Rate of Apoptosis }\end{array}$ & Oncogene & [155] \\
\hline & let-7 & EC, OCSC & ceRNA & $\begin{array}{c}\text { Promotes Tumor Cell Migration and } \\
\text { Invasion }\end{array}$ & Oncogene & [145] \\
\hline HOTAIR & PRC2 & / & Scaffold & $\begin{array}{c}\text { The trimethylation of the H3K } 27 \\
\text { Histone and Consequent Gene } \\
\text { Silencing }\end{array}$ & Oncogene & [156] \\
\hline \multirow{10}{*}{ MALAT1 } & $\operatorname{miR}-22$ & EOC & ceRNA & $\begin{array}{l}\text { Increased Cell Proliferation, } \\
\text { Migration, Invasion, Tumor Growth, } \\
\text { and Metastasis }\end{array}$ & Oncogene & [179] \\
\hline & miR-506 & OC & ceRNA & $\begin{array}{c}\text { Upregulation of iASPP and Cell } \\
\text { Proliferation }\end{array}$ & Oncogene & [180] \\
\hline & miR-200c & $\mathrm{EC}, \mathrm{EOC}$ & ceRNA & Increased Invasive Capacity & Oncogene & {$[181,238]$} \\
\hline & miR-143-3p & EOC & ceRNA & Upregulation of $C M P K$ & Oncogene & [182] \\
\hline & miR-200a & $\mathrm{EC}$ & ceRNA & \multirow{2}{*}{$\begin{array}{l}\text { Promotes Autophagy and Invasion } \\
\text { Upregulation of PHF19, Leading to } \\
\text { OC Progression } \\
\text { Promotes Proliferation and Inhibits }\end{array}$} & Oncogene & [96] \\
\hline & $\operatorname{miR}-211$ & EC, HGSOC & ceRNA & & Oncogene & [183] \\
\hline & miR-503-5p & EOC & ceRNA & $\begin{array}{c}\text { Promotes Proliferation and Inhibits } \\
\text { Apoptosis Through the JAK2-STAT3 } \\
\text { Pathway }\end{array}$ & Oncogene & [184] \\
\hline & miR-1271-5p & HGSOC, EC & ceRNA & $\begin{array}{c}\text { Upregulation of E2F5 Expression, } \\
\text { Mediates DPP-Resistant OC } \\
\text { Development }\end{array}$ & Oncogene & [188] \\
\hline & SRSF1 & EOC & Scaffold & $\begin{array}{l}\text { Leading to Alternative Splicing of } \\
\text { KIF1B Leading to Production of the } \\
\text { Pro-Apoptotic Isoform }\end{array}$ & Oncogene & [185] \\
\hline & YAP & $\mathrm{EC}$ & ceRNA & $\begin{array}{l}\text { Inhibition of Nucleus-Cytoplasm } \\
\text { Translocation, Resulting in } \\
\text { Enhanced Activity and Promotion } \\
\text { of Stemness Phenotype }\end{array}$ & Oncogene & [189] \\
\hline
\end{tabular}


Table 2. Cont.

\begin{tabular}{|c|c|c|c|c|c|c|}
\hline lncRNA & Target & OC Type & $\begin{array}{l}\text { Mode of } \\
\text { Action }\end{array}$ & Effect & Role & Reference \\
\hline & AMPK & GCT & Unknown & $\begin{array}{c}\text { Proliferation, Viability, Inhibition of } \\
\text { Autophagy, Downregulation of } \\
A M P K\end{array}$ & Oncogene & [191] \\
\hline & multiple & GCT & $\begin{array}{l}\text { Signal } \\
\text { Molecule }\end{array}$ & $\begin{array}{c}\text { Downregulation of p21, p53, p-JNK, } \\
\text { p-ERK1/2; Upregulation of CDK2, } \\
\text { Cyclin D1, p-P38 MAPK }\end{array}$ & Oncogene & [187] \\
\hline \multirow{6}{*}{ MEG3 } & ATG3 & EOC & Scaffold & $\begin{array}{l}\text { Protects ATG3 mRNA from } \\
\text { Degradation, Induces Autophagy }\end{array}$ & $\begin{array}{c}\text { Tumor } \\
\text { Suppressor }\end{array}$ & [95] \\
\hline & miR-214 & $\mathrm{EOC}$ & ceRNA & Reduction of Resistance to Cisplatin & $\begin{array}{c}\text { Tumor } \\
\text { Suppressor }\end{array}$ & [203] \\
\hline & PTEN & $\mathrm{EOC}$ & Unknown & $\begin{array}{l}\text { Upregulation of PTEN, Inhibition of } \\
\text { Cell Proliferation, Induction of } \\
\text { Apoptosis, Cell Cycle Block }\end{array}$ & $\begin{array}{l}\text { Tumor } \\
\text { Suppressor }\end{array}$ & [200] \\
\hline & miR-219a-5p & OC & ceRNA & $\begin{array}{l}\text { Downregulation of } E G R F \text {, Inhibition } \\
\text { of Proliferation and Induction of } \\
\text { Apoptosis }\end{array}$ & $\begin{array}{l}\text { Tumor } \\
\text { Suppressor }\end{array}$ & [239] \\
\hline & miR-30e-3p & OC & ceRNA & $\begin{array}{l}\text { Upregulation of } L A M A 4, \text { Reduced } \\
\text { Proliferation, Migration, and } \\
\text { Invasion of OC Cells }\end{array}$ & $\begin{array}{l}\text { Tumor } \\
\text { Suppressor }\end{array}$ & [199] \\
\hline & miR-205-5p & OC & ceRNA & $\begin{array}{l}\text { Inhibition of Cell Viability, } \\
\text { Migration, and Invasion, Induction } \\
\text { of Apoptosis }\end{array}$ & $\begin{array}{l}\text { Tumor } \\
\text { Suppressor }\end{array}$ & [240] \\
\hline \multirow{7}{*}{ NEAT1 } & miR-34a-5p & OC & ceRNA & $\begin{array}{c}\text { Promotes Proliferation by } \\
\text { Upregulating } B C L 2\end{array}$ & Oncogene & [208] \\
\hline & miR-124-3p & OC & ceRNA & $\begin{array}{l}\text { Promotes Cell Proliferation and } \\
\text { Invasion, NEAT1 Expression is } \\
\text { Stabilized by HuR Protein }\end{array}$ & Oncogene & [209] \\
\hline & miR-382-3p & OC & ceRNA & $\begin{array}{c}\text { Promotes ROCK1-Mediated } \\
\text { Metastasis }\end{array}$ & Oncogene & [210] \\
\hline & miR-506 & EOC & ceRNA & $\begin{array}{c}\text { Promotes Cell Proliferation and } \\
\text { Migration, NEAT1 is Stabilized by } \\
\text { LIN28B }\end{array}$ & Oncogene & [211] \\
\hline & miR-1321 & OC & ceRNA & $\begin{array}{c}\text { Increased Expression of TJP3, } \\
\text { Enhances EMT, Invasion, and } \\
\text { Migration }\end{array}$ & Oncogene & [212] \\
\hline & $\mathrm{miR}-4500$ & OC & ceRNA & $\begin{array}{l}\text { Increased Expression of BZW1, } \\
\text { Enhances Cell Proliferation, Colony } \\
\text { Formation, Migration, Invasion, and } \\
\text { Glycolysis, Reduces Apoptosis }\end{array}$ & Oncogene & [213] \\
\hline & $\operatorname{miR}-365$ & EC, HGSOC & ceRNA & $\begin{array}{c}\text { Increased Expression of FGF9, } \\
\text { Promotes Cell Proliferation and } \\
\text { Angiogenesis }\end{array}$ & Oncogene & [214] \\
\hline \multirow{5}{*}{ UCA1 } & $\mathrm{miR}-485-5 \mathrm{p}$ & EOC & ceRNA & $\begin{array}{l}\text { Increased Expression of } M M P 14, \\
\text { Possible Role in Metastasis of OC }\end{array}$ & Oncogene & [221] \\
\hline & AMOT & EOC & ceRNA & $\begin{array}{l}\text { Enhances AMOT-YAP Interaction, } \\
\text { Activation of YAP Target Genes, }\end{array}$ & Oncogene & [223] \\
\hline & miR-143 & OC & ceRNA & $\begin{array}{c}\text { Upregulation of FOSL2, Increased } \\
\text { Cisplatin Resistance }\end{array}$ & Oncogene & [227] \\
\hline & miR-654-5p & OC & ceRNA & $\begin{array}{c}\text { Upregulation of SIK2, Resistance to } \\
\text { Paclitaxel }\end{array}$ & Oncogene & [228] \\
\hline & miR-129 & OC & ceRNA & $\begin{array}{c}\text { Upregulation of } A B C B 1 \text {, Resistance } \\
\text { to Paclitaxel }\end{array}$ & Oncogene & [229] \\
\hline
\end{tabular}


Table 2. Cont.

\begin{tabular}{|c|c|c|c|c|c|c|}
\hline $\operatorname{lncRNA}$ & Target & OC Type & $\begin{array}{l}\text { Mode of } \\
\text { Action }\end{array}$ & Effect & Role & Reference \\
\hline \multirow{4}{*}{ XIST } & miR-149-3p & EOC & ceRNA & $\begin{array}{c}\text { Upregulation of FOXP3 Leading to } \\
\text { OC Cell Proliferation }\end{array}$ & Oncogene & [235] \\
\hline & miR-101-3p & HGSOC & ceRNA & $\begin{array}{l}\text { Upregulation of } \mathrm{C} / \mathrm{EBP} \alpha \text { and } K L F 6 \\
\text { Leading to Macrophage Polarization } \\
\text { to Affect Cell Proliferation of OC }\end{array}$ & Oncogene & [237] \\
\hline & miR-214-3p & HGSOC & ceRNA & $\begin{array}{c}\text { Suppression of Cell Proliferation, } \\
\text { Invasion, Increased } \\
\text { Chemosensitivity, Inhibition of } \\
\text { Tumor Growth In Vivo }\end{array}$ & $\begin{array}{c}\text { Tumor } \\
\text { Suppressor }\end{array}$ & [236] \\
\hline & miR-106a & OC & ceRNA & $\begin{array}{l}\text { Decrease in Cell Proliferation and } \\
\text { Activation of Apoptosis, In Vivo } \\
\text { Tumor Growth Deceleration }\end{array}$ & $\begin{array}{c}\text { Tumor } \\
\text { Suppressor }\end{array}$ & [234] \\
\hline
\end{tabular}

\subsection{Other IncRNAs Involved in Rare Ovarian Cancers}

LncRNA growth arrest-specific 5 (GAS5) is upregulated in the plasma of patients with polycystic ovary syndrome (PCOS). This was also demonstrated in the ovarian granulosa cell tumor cell line KGN, where it leads to upregulation of IL6, and decreased apoptosis rate of these cells [241]. HLA complex P5 (HCP5) promotes cell proliferation and inhibits apoptosis in the KGN cell line through the miR-27a-3p-IGF1 axis [242]. In contrast, NPTN intronic transcript 1 (NPTN-IT1, or lncRNA-LET) is downregulated in KGN cells, and its overexpression inhibited cell viability and migration and promoted apoptosis [243].

Upregulation of long intergenic non-protein coding RNA 324 (LINC00324) has been found in immature ovarian teratocarcinoma (IOT) tissues and cells. LINC00324 acts as a miR-214-5p sponge, thereby removing its inhibition of CDK6, CCND1, MDM2, and MDM4, consequently increasing IOT cell proliferation and decreasing apoptosis [244].

A study by Yan et al., identified neuroblastoma-associated transcript 1 (NBAT1) as a marker of favorable prognosis in OC. The study included 46 serous OC and 11 OC tumors of different origins, but there was no additional information on these other subtypes. However, the authors state that there was no difference between histological subtypes, suggesting that this marker is applicable for ROCs as well [245].

Table 3. Other lncRNAs with a role in ROCs. ROC analyzed in these papers include GCT-granulosa cell tumors, IOTimmature ovarian teratocarcinoma, and undefined (other).

\begin{tabular}{|c|c|c|c|c|c|c|}
\hline lncRNA & Target & OC Type & $\begin{array}{l}\text { Mode of } \\
\text { Action }\end{array}$ & Effect & Role & Reference \\
\hline GAS5 & IL6 & GCT & Unknown & $\begin{array}{l}\text { Upregulation of IL6, } \\
\text { Decreased Apoptosis }\end{array}$ & Oncogene & [241] \\
\hline HCP5 & miR-27a-3p & GCT & ceRNA & $\begin{array}{c}\text { Proliferation, } \\
\text { Inhibition of Apoptosis }\end{array}$ & Oncogene & [242] \\
\hline NPTN-IT1 & NF90 & GCT & Scaffold & $\begin{array}{c}\text { Reduced Cell Viability } \\
\text { and Migration, } \\
\text { Increased Apoptosis }\end{array}$ & $\begin{array}{c}\text { Tumor } \\
\text { Suppressor }\end{array}$ & [243] \\
\hline LINC00324 & miR-214-5p & IOT & ceRNA & $\begin{array}{c}\text { Proliferation, } \\
\text { Decreased Apoptosis }\end{array}$ & Oncogene & [244] \\
\hline NBAT1 & $\begin{array}{c}\text { ERK1/2 and } \\
\text { AKT Signaling } \\
\text { Pathways }\end{array}$ & $\begin{array}{c}\text { Serous and } \\
\text { Other }\end{array}$ & Unknown & $\begin{array}{l}\text { Inhibition of Cell } \\
\text { Proliferation, Invasion, } \\
\text { and Migration }\end{array}$ & $\begin{array}{c}\text { Tumor } \\
\text { Suppressor }\end{array}$ & [245] \\
\hline
\end{tabular}




\section{Circulating lncRNAs as Diagnostic and Prognostic Biomarkers for OCs}

Liquid biopsies are considered a minimally invasive means for managing cancer patients, and they can be applied in diagnosis, follow-up, and prediction to therapy. Liquid biopsies can be used for the detection of circulating tumor cells (CTCs), cell-free tumor DNA (ctDNA), and non-coding RNAs [246]. Circulating non-coding RNAs (miRNA and $\operatorname{lncRNAs}$ ) have been proposed as potential biomarkers for the early detection of OC. In particular, multiple miRNA panels have been proposed as screening tools in clinical practice [247]. Several publications examine the possible role of lncRNAs in the diagnosis, prediction, and prognosis of OCs. Non-coding RNAs can be secreted from EOC cells via exosomes, and in turn exosomes from the serum of patients can be used for detection of these non-coding RNAs. Elevated exosomal levels of MALAT1 in the serum of patients were highly correlated with advanced and metastatic subtypes of EOC, and an independent predictive factor for overall survival [105]. Exosomal HIF1A-AS2 levels from the serum of EOC patients have been associated with poorer overall survival and suggested as a noninvasive predictive biomarker for unfavorable prognosis [248]. LOXL1-AS1 was analyzed in the plasma of EOC patients, and its expression was associated with advanced FIGO stage, distant metastases, and short overall survival. It was proposed to be an independent diagnostic and prognostic factor in EOC [249]. A meta-analysis, which encompassed 1732 OC patients and 3958 controls, evaluated the diagnostic accuracy of ctDNA, miRNAs, and lncRNAs and found, albeit on a small number of studies, that lncRNAs were more accurate than miRNAs in diagnosing OC, with similar specificities. The authors claim that combining ctDNA, miRNA, and lncRNA biomarkers is the best option as it avoids the shortcomings of single biomarkers regarding sensitivity and specificity [250]. The major drawbacks and challenges in the detection of lncRNAs from liquid biopsies, and their use as biomarkers, is their low concentration in the serum/plasma and potential contamination with genomic DNA. Even though nowadays RNA extraction kits are able to remove the bulk of contaminating genomic DNA, nevertheless care must be taken during sample preparation, as contamination with genomic DNA in RNA preparations can lead to a false positive signal in qRT-PCR assays. This is especially true for lncRNAs encoded by a single exon, such as MALAT1 [251]. Soda et al., have recently demonstrated that HOTAIR can be detected from plasma samples using electrochemical detection, and they propose that this assay could be used in a clinical setting for the detection of various lncRNA biomarkers [172]. It is also possible to detect microproteins encoded by lncRNAs in the extracellular vesicles in human plasma samples, and these microproteins could be used as diagnostic markers [252]. More studies of different circulating biomarkers in OCs are needed to assemble a good panel of miRNA/lncRNA targets for the diagnosis of OC and for determining their response to therapy. This could lead to better early detection and a personalized approach to therapy with a better outcome for OC patients.

Expression levels of circulating extracellular or exosome/EV lncRNAs associated with body fluids such as plasma/serum could serve as a potential biomarker for routine usage and a complementary liquid biopsy for the risk of ovarian tumor metastasis, recurrence, drug resistance, and potentially early detection. As single markers sometimes lack sensitivity and specificity, designing biomarker panels has been suggested as a good option for early detection, diagnosis, and prediction of recurrence. Such panels of lncRNAs have already been proposed for hepatocellular [253], liver [254], bladder [255,256], breast and cervical cancer [257]. A lncRNA panel as a candidate prognostic biomarker for OC has been proposed by Zhan et al. [258], but the focus was mainly on the construction of panels that can assess the response to therapy of OC patients, for example for platinum-based chemoresistance $[259,260]$ or paclitaxel resistance [261]. LncRNA has the potential to be companion diagnostic tools alongside ctDNA and even CTCs in predicting recurrence and resistance, but how they could be incorporated into a screening program remains to be determined. In addition, a panel distinguishing between rare OC subtypes could prove to be most beneficial for diagnostic purposes. 


\section{Strategies for Targeting lncRNAs as a Treatment for OCs}

The important role of lncRNAs in various biological processes related to carcinogenesis, together with their cancer-specific expression patterns, has made lncRNAs promising therapeutic targets. Therefore, many strategies have been developing for their targeting $[262,263]$. Generally, there are two main approaches, which have already been applied for targeting different lncRNAs in OC: to alter their expression level or to inhibit their interactions with other macromolecules [13].

Oncogenic lncRNAs are overexpressed in cancers so their expression can be suppressed using various, mostly nucleic acids-based techniques. Most commonly used methods are based on RNA interference (RNAi), like small interfering RNAs (siRNAs) or short/small hairpin RNAs (shRNAs) [264]. siRNAs are short, double-stranded (ds) RNAs that unwind into single strands (ss), bind to the RNA-induced silencing complex (RISC), and base-pair with targeting lncRNAs. That leads to Argonaute protein-dependent degradation of the target transcripts. Chemically synthesized siRNAs are usually directly delivered into the cytoplasm through transfection. shRNAs are produced as ss molecules 50-70 nucleotides long which form hairpin-like structures. They are usually encoded in DNA vectors and introduced into cells by plasmid transfection or viral transduction. They undergo processing and exert their mechanism of action similarly to siRNAs [265]. Presumably, all lncRNAs characterized in Tables 2 and 3 as oncogenes, i.e., those which are over-expressed in OC and thus contribute to its initiation, tumorigenesis, or metastasis, could be targeted using RNAi methods. LncRNA silencing by siRNA or shRNA is probably the most used method for deducing lncRNA function in vitro [266].

LncRNA expression can also be suppressed using antisense oligonucleotides (ASOs), locked nucleic acid GapmeRs (LNA GapmeRs), or antagonists to natural antisense transcripts (antagoNATs) [267]. ASOs are ss antisense oligonucleotides made up of a DNA stretch at the central part with flanking RNA nucleotides. The DNA part with the target lncRNA, through Watson-Crick base pairing, forms a DNA/RNA heteroduplex which is cleaved by endogenous RNase H1 [268]. For instance, targeting lncRNA MALAT1, which is overexpressed in both common and rare OCs, by ASOs, inhibited tumor growth and metastasis of breast [269] and lung cancer [270]. LNA GapmeRs share structural and functional similarities with ASOs but have chemically modified LNA in flanking parts which increases their binding affinity and nuclease resistance [271]. LNAs have been constructed for targeting XIST [272], a lncRNA both up- and down-regulated in EOCs. NATs are coded from the opposite strand of the host gene locus and regulate expression of either sense transcripts of the same locus (cis-NATs) or transcripts from other genomic loci (transNATs). They mediate transcriptional silencing through histone-modifying complexes [273]. AntagoNATs are ss oligonucleotides designed to inhibit sense-antisense transcripts interactions and thus they can eliminate the epigenetic silencing effect of lncRNAs that act as NATs [274]. The first successfully applied antagoNAT was against BDNF-AS, a NAT that represses transcription of brain-derived neurotrophic factor (BDNF) gene [274]. This approach could potentially be used for regulating the expression of ovarian $B D N F$, which promotes survival, migration, and attachment of tumor precursors originated from TP53-mutated fallopian tube epithelial cells, precursors of HGSOC [275]. AntagoNATs could also be designed for targeting other NATs commonly dysregulated in common and rare OCs, such as HOTAIR, MALAT1, MEG3, and GAS5 [273].

Other methods used for silencing lncRNA expression are mixmers and deoxy/ ribozymes. Mixmers are built of chemically modified nucleotides like LNAs and different types of monomers. They sterically inhibit interactions between lncRNAs, ribonucleoproteins, or nucleic acids. They are used for preventing the formation of epigenetic remodeling complexes, altering gene expression and alternative splicing, repairing defective RNAs, and restoring protein production [276]. So far, the best-described example is a mixmer consisting of LNA interspersed with 2'-O-methyl nucleotides with a high-affinity for SMN$A S 1$, an antisense transcript that represses expression of survival motor neuron 2 (SMN2) gene by recruiting the PRC2 to its locus [277]. For treating OCs, a similar approach could be 
used, for instance, for targeting interactions between PRC2 and HOTAIR [156] or XIST [278]. Deoxyribozymes are enzymatic ssDNA molecules that bind target RNA through WatsonCrick base pairing and catalyze RNA cleavage (ribonucleases) [279]. Similarly, there exist engineered ribozymes that have better catalytic activities and more specific substrate recognition domains [280]. A site-specific deoxyribozymes have been designed to cleave RNAs that have $N^{6}$-methyladenosine (m6A) modifications [281]. In the meantime, it was discovered that many lncRNAs such as MALAT1 [282], XIST [283], HOTAIR [284], GAS5 [285], or DANCR [286] contain one to several m6A modifications, and thus deoxyribozymes could be used as therapeutics for OC [287].

Gene-editing methods like zinc finger nucleases (ZFNs), transcription activatorlike effector nucleases (TALENs), and clustered regularly interspaced short palindromic repeats/CRISPR-associated protein 9 (CRISPR/Cas9) system can be used to suppress lncRNA expression [288,289]. It is worth noting that, unlike protein-coding genes, lncRNA genes are not vulnerable to small insertions, deletions, or frameshift mutations so their genes must be edited to a much larger extent. In addition, lncRNA expression can sterically be repressed by CRISPR interference (CRISPRi) [290]. CRISPRi uses guide RNA (gRNA) for recognizing the target gene and catalytically dead Cas9 (dCas9) protein without endonuclease activity for blocking initiation or elongation of transcription. Similarly, CRISPR activation (CRISPRa) can be used for sequence-specific activation of gene expression. Besides several large scales, genome-wide deletion of up to several thousand lncRNA loci [291,292], CRISPRi was successfully used for knocking out particular, single lncRNA such as MALAT1 [293], XIST [294], HOTAIR [295], NEAT1 [296] or UCA1 [297]. Furthermore, instead of transcriptional silencing of the whole lncRNA gene, CRISPR/Cas9 could be also used for "repairing" alleles of lncRNAs genes found to be associated with ovarian cancer susceptibility, such as HOTAIR polymorphism rs920778 [298].

Manipulation with lncRNAs expression levels with any of the aforementioned methods could be used to interfere with the function of lncRNAs as miRNA sponges. Increased expression of lncRNAs that bind oncomiRs or decreased expression of lncRNAs that bind tumor-suppressor miRNAs could normalize gene regulatory network and signaling pathways, and reverse malignant phenotype, just like using miRNA mimics or antagomiRs [299]. For instance, since the expression of ceRNA SNHG5 is reduced in paclitaxel-resistant OC patients, either SNHG5 overexpression or miR-23a inhibition could enhance paclitaxel sensitivity [300]. Similarly, ceRNA UCA1 can sponge miR-654-5p, while its knockdown enhances miR-654-5p expression, which reduces ovarian tumor cells viability in vitro and in vivo [301].

As mentioned above, the second general therapeutic approach for targeting lncRNAs in OC would be to abolish their function by inhibiting their interactions with other macromolecules, either through competition or steric blockade. There are several approaches including aptamers, nanobodies, small molecules, and RNA decoys [302]. Aptamers are short (up to 200 nucleotides) ss DNA or RNA molecules with high specificity and affinity for their targets and are considered nucleic acid analogs of antibodies [303]. However, they have better tissue penetration, lower immunogenicity, and in vivo stability. They act through dynamic three-dimensional structure, by recognizing the secondary structure of lncRNAs, and thus interfering with lncRNA-protein interactions [304]. For instance, there exist aptamers against HOTAIR [305] and H19 [306], which could be used as OC therapeutics. Nanobodies are heavy chain-only antibodies (HCAbs), found naturally in sharks and camelids, that is built of a single variable domain ( $\mathrm{VHH}$ ), which is similar to the Fab fragment of human IgG antibodies and thus non-immunogenic [307]. They have both high affinity and specificity and the potential to interrupt lncRNA-RBP interactions [308]. Nanobodies can be designed to specifically target highly structured RNA molecules [309], and since it is known that many lncRNAs such as MALAT1 [310], NEAT1 [311], XIST [230], or HOTAIR [312] are well-structured, this approach could be used for treating OC types in which those lncRNAs are overexpressed. Small molecules (chemical compounds), by binding to either lncRNAs or RNA-binding proteins (RBPs), can change their secondary or 
tertiary structures or mask protein-binding sites on lncRNAs or lncRNA-binding domains of RBPs, and thus disrupt interactions between them [313,314]. Similar to nanobodies, highly structured parts of lncRNAs can also be targeted by small molecules. Therefore, the use of high-throughput screening identified a small molecule ellipticine that can inhibit interactions between HOTAIR-EZH2 and BDNF-AS-EZH2 [315]. Furthermore, several small molecules have been discovered that can target MALAT1 [316,317]. RNA decoys or imitators of lncRNAs could be designed to act through binding to and sequestering of proteins, to disrupt the creation of functional lncRNA-RBP complexes [318]. One such example is an anti-HIV decoy that targets the HIV-1 Tat protein. It has a trans-activation response (TAR) element RNA hairpin and binds to the Tat protein. This decoy localizes in the nucleolus while natural TAR RNA is localized in the nucleus [319]. Another example is a mimic of HULC, a lncRNA that interacts with phenylalanine hydroxylase (PAH) and modulates its function. HULC depletion causes reduced enzymatic activities of PAH, which is a characteristic of metabolic disorder phenylketonuria. The introduction of HULC mimics successfully restores the function of that liver lncRNA and reduces excess phenylalanine levels [320]. Therefore, this therapeutic approach could be used for treating OC types in which reduced levels of certain lncRNA, e.g., those that were in Tables 2 and 3 classified as a tumor suppressor, is a cause for OC initiation, tumorigenesis, or metastasis.

Regulatory regions of lncRNAs could be also used for constructing more efficient drugs. There exists a DNA plasmid called H19-DTA (BC-819) that carries the gene for A subunit of diphtheria toxin under the regulation of the H19 promoter and it is used for treating cancers with high $H 19$ expression such as OC [321]. Its safety and efficacy for treating ovarian and peritoneal cancer patients with advanced recurrent disease had already been proven in the Phase I/IIa clinical trial [322].

All previously described methods consider targeting a lncRNA of interest as a primary therapeutic goal for treating OCs. However, targeting lncRNAs could also be used to enhance the efficiency of already applied therapeutic regimes, since for many OC-related lncRNAs described in this paper their involvement in resistance to radio- and chemotherapy was mentioned. This has been comprehensively reviewed in [323,324].

Although constantly on the rise in recent years [325], RNA-based or RNA-targeted therapeutic approaches still have many limitations, such as inefficient delivery to the target tissue, toxicity and immunogenicity, and off-target effects (non-selectivity). Over the past decade, in parallel with the development of novel RNA therapeutics, promising approaches have been developed to overcome these hurdles and to boost their success [326]. Hopefully, this will bring to more (successful) clinical trials for targeting long non-coding RNAs as a potential therapeutic approach for the treatment of OCs.

\section{Online Resources for lncRNA Research}

Expanding interest in lncRNA research has led to the accumulation of a vast amount of knowledge that has to be properly analyzed, organized, and made available for the wider scientific community. Therefore, a constantly growing number of web resources and bioinformatical tools have been developed that can help many different aspects of lncRNA research [327,328]. However, for an ordinary wet-lab lncRNA cancer researcher without advanced computational skills, databases, and online tools would be the most useful [329]. Unlike miRbase for microRNAs [330], there is still no primary, central repository for lncRNAs. In Table 4 there is a shortlist of the best known and most used lncRNA web resources.

Table 4. A short overview of online resources useful for lncRNA research in cancer.

\begin{tabular}{ccc}
\hline Type & Web Address & Reference \\
\hline General lncRNA Databases & & \\
RNAcentral & https://rnacentral.org/ & {$[331]$} \\
LNCipedia & https://lncipedia.org/ & {$[332]$} \\
LncBook & http://bigd.big.ac.cn/lncbook/index & {$[333]$} \\
lncRNAdb & http://lncrnadb.org/ & {$[334]$} \\
\hline
\end{tabular}


Table 4. Cont.

\begin{tabular}{|c|c|c|}
\hline Type & Web Address & Reference \\
\hline lncRNome & http://genome.igib.res.in/lncRNome/ & [335] \\
\hline GENCODE & https://www.gencodegenes.org/ & [55] \\
\hline \multicolumn{3}{|l|}{ General Expression Databases } \\
\hline GTEx & https://gtexportal.org/home/ & [336] \\
\hline GEO & https://www.ncbi.nlm.nih.gov/geo/ & [337] \\
\hline TCGA & https://portal.gdc.cancer.gov/ & [338] \\
\hline Expression Atlas & https://www.ebi.ac.uk/gxa/home & [339] \\
\hline \multicolumn{3}{|c|}{ The lncRNA-Specific Expression Databases } \\
\hline NONCODEV5 & http://v5.noncode.org/index.php & [340] \\
\hline NRED & http://jsm-research.imb.uq.edu.au/nred/cgi-bin/ncrnadb.pl & [341] \\
\hline LncExpDB & https://bigd.big.ac.cn/lncexpdb/ & [342] \\
\hline LncSpA & http://bio-bigdata.hrbmu.edu.cn/LncSpA/ & [343] \\
\hline \multicolumn{3}{|c|}{ General Disease- and Cancer-Specific lncRNA Databases } \\
\hline TANRIC & https://www.tanric.org/ & [344] \\
\hline LncRNADisease 2.0 & http://www.rnanut.net/lncrnadisease/ & [345] \\
\hline Lnc2Cancer 3.0 & http://www.bio-bigdata.com/lnc2cancer/ & [346] \\
\hline lncRNASNP2 & http://bioinfo.life.hust.edu.cn/lncRNASNP/ & [347] \\
\hline Lnc2Catlas & https://lnc2catlas.bioinfotech.org/ & [348] \\
\hline \multicolumn{3}{|c|}{ Function-Specific and Other Useful lncRNA Databases } \\
\hline DIANA-LncBase v3 & https://diana.e-ce.uth.gr/lncbasev3/home & [349] \\
\hline SEEKR & http://seekr.org/home & [350] \\
\hline LPI-MiRNA & $\begin{array}{c}\text { https:/ / github.com/zyk2118216069/LncRNA-protein- } \\
\text { interactions-prediction }\end{array}$ & [351] \\
\hline LncRNAWiki & http://lncrna.big.ac.cn & [352] \\
\hline lncRNA Blog & https://www.lncrnablog.com/ & - \\
\hline
\end{tabular}

\section{Conclusions and Future Perspectives}

Recently we celebrated the 20th anniversary of publishing the draft human genome sequence. Initially, only about $2 \%$ of the human genome was reported to comprise proteincoding genes, and the rest referred to as "junk" DNA, it has become increasingly evident that this "junk" DNA is a goldmine for many regulatory non-coding transcripts. One type of such transcript is the lncRNAs. Consequently, their mechanisms of action and the molecular processes which they regulate are still being unraveled. As anticipated, their causative roles in the development and progression of many human neoplasms, including OCs, are becoming increasingly evident.

The major drawback in discovering the (in)distinctive roles of lncRNAs in common and rare OCs is the lack of studies that clearly and properly separate the OC subtypes. One potential reason for that could be both clinicians' and researchers' inexperience in diagnosing rare gynecological cancers. On the other hand, the manuscript reviewers should insist that authors need to put more effort into describing their clinical samples. Hopefully, international collaborations such as the GYNOCARE COST Action will contribute to a more unified and standardized diagnosis and classification of ROCs [1].

Long non-coding RNA molecules are promising diagnostic and prognostic biomarkers for ROCs [353]. Currently, we have been witnessing an accelerated development and an increased efficiency of RNA-bases therapeutics. Further in-depth knowledge about lncRNAs should direct researchers and pharmaceutical companies in the post-COVID era to become more interested in lncRNAs as potential therapeutic agents or therapeutic targets. These emerging technologies and approaches could certainly improve the quality of life and outcome of many women with ROCs. 
Author Contributions: Conceptualization, P.O., M.S., R.D.F., and J.C.-A.; writing-original draft preparation, P.O., and M.S.; writing-review and editing, P.O., M.S., J.C.-A., R.D.F., S.S., S.O., M.P.W.; funding acquisition, J.C.-A. All authors have read and agreed to the published version of the manuscript.

Funding: The publication of this manuscript was funded by the European Cooperation in Science \& Technology program (EU COST)-COST Action CA18117: GYNOCARE_“European network for Gynaecological Rare Cancer research: From Concept to Cure".

Conflicts of Interest: The authors declare no conflict of interest.

$\begin{array}{ll}\text { Abbreviations } \\ \text { BEP } & \text { bleomycin, etoposide, and cisplatin } \\ \text { CAF } & \text { cancer-associated fibroblasts } \\ \text { ceRNA } & \text { competing endogenous RNA } \\ \text { CSC } & \text { cancer stem cells } \\ \text { EC } & \text { endometroid carcinoma } \\ \text { EMT } & \text { epithelial to mesenchymal transition } \\ \text { EOC } & \text { epithelial ovarian cancer } \\ \text { FIGO } & \text { Fédération Internationale de Gynécologie et d'Obstétrique } \\ \text { GCT } & \text { granulosa cell tumor } \\ \text { HGSOC } & \text { high-grade serous ovarian cancer } \\ \text { HOTAIR } & \text { HOX transcript antisense RNA } \\ \text { IOT } & \text { immature ovarian teratocarcinoma } \\ \text { LGSOC } & \text { low-grade serous ovarian cancer } \\ \text { lincRNA } & \text { long intergenic non-coding RNA } \\ \text { lncRNA } & \text { long non-coding RNA } \\ \text { MALAT1 } & \text { metastasis-associated lung adenocarcinoma transcript 1 } \\ \text { MSC } & \text { mesenchymal stem cell } \\ \text { MET } & \text { mesenchymal to epithelial transition } \\ \text { miRNA/miR } & \text { microRNA } \\ \text { MOC } & \text { mucinous ovarian carcinoma } \\ \text { NAT } & \text { natural antisense transcript } \\ \text { ncRNA } & \text { non-coding RNA } \\ \text { OC } & \text { ovarian cancer } \\ \text { OCCC } & \text { ovarian clear cell carcinoma } \\ \text { OCSC } & \text { ovarian cancer stem cells } \\ \text { PCOS } & \text { polycystic ovary syndrome } \\ \text { PRC } & \text { Polycomb Repressive Complex } \\ \text { RNAi } & \text { RNA interference } \\ \text { ROC } & \text { rare ovarian cancer } \\ \text { siRNA } & \text { small interfering RNA } \\ \text { shRNA } & \text { short hairpin RNA } \\ \text { XIST } & \text { X-inactive specific transcript } \\ & \end{array}$

\section{References}

1. Di Fiore, R.; Suleiman, S.; Ellul, B.; O’Toole, S.; Savona-Ventura, C.; Felix, A.; Napolioni, V.; Conlon, N.; Kahramanoglu, I.; Azzopardi, M.J. GYNOCARE Update: Modern Strategies to Improve Diagnosis and Treatment of Rare Gynecologic TumorsCurrent Challenges and Future Directions. Cancers 2021, 13, 493. [CrossRef]

2. Sung, H.; Ferlay, J.; Siegel, R.L.; Laversanne, M.; Soerjomataram, I.; Jemal, A.; Bray, F. Global Cancer Statistics 2020: GLOBOCAN Estimates of Incidence and Mortality Worldwide for 36 Cancers in 185 Countries. CA Cancer J. Clin. 2021, 71, 209-249. [CrossRef]

3. Lisio, M.-A.; Fu, L.; Goyeneche, A.; Gao, Z.-H.; Telleria, C. High-Grade Serous Ovarian Cancer: Basic Sciences, Clinical and Therapeutic Standpoints. Int. J. Mol. Sci. 2019, 20, 952. [CrossRef] [PubMed]

4. Cancer Research UK. Available online: https://www.cancerresearchuk.org/home (accessed on 17 August 2021).

5. Debuquoy, C.; Romeo, C.; Vanacker, H.; Ray-Coquard, I. Rare ovarian tumors: An update on diagnosis and treatment. Int. J. Gynecol. Cancer 2020, 30, 879-887. [CrossRef] [PubMed]

6. Jayde, V.; White, K.; Blomfield, P. Symptoms and diagnostic delay in ovarian cancer: A summary of the literature. Contemp. Nurse 2010, 34, 55-65. [CrossRef] [PubMed] 
7. Gao, N.; Li, Y.; Li, J.; Gao, Z.; Yang, Z.; Li, Y.; Liu, H.; Fan, T. Long Non-Coding RNAs: The Regulatory Mechanisms, Research Strategies, and Future Directions in Cancers. Front. Oncol. 2020, 10, 8817. [CrossRef] [PubMed]

8. Salamini-Montemurri, M.; Lamas-Maceiras, M.; Barreiro-Alonso, A.; Vizoso-Vázquez, Á.; Rodríguez-Belmonte, E.; QuindósVarela, M.; Cerdán, M.E. The Challenges and Opportunities of LncRNAs in Ovarian Cancer Research and Clinical Use. Cancers 2020, 12, 1020. [CrossRef]

9. Zhan, L.; Li, J.; Wei, B. Long non-coding RNAs in ovarian cancer. J. Exp. Clin. Cancer Res. 2018, 37, 1-13. [CrossRef] [PubMed]

10. Wang, J.-Y.; Lu, A.-Q.; Chen, L.-J. LncRNAs in ovarian cancer. Clin. Chim. Acta 2019, 490, 17-27. [CrossRef]

11. Oncul, S.; Amero, P.; Rodriguez-Aguayo, C.; Calin, G.; Sood, A.K.; Lopez-Berestein, G. Long non-coding RNAs in ovarian cancer: Expression profile and functional spectrum. RNA Biol. 2020, 17, 1523-1534. [CrossRef]

12. Braga, E.A.; Fridman, M.V.; Moscovtsev, A.A.; Filippova, E.A.; Dmitriev, A.A.; Kushlinskii, N.E. LncRNAs in Ovarian Cancer Progression, Metastasis, and Main Pathways: ceRNA and Alternative Mechanisms. Int. J. Mol. Sci. 2020, 21, 8855. [CrossRef] [PubMed]

13. Bhardwaj, V.; Tan, Y.Q.; Wu, M.M.; Ma, L.; Zhu, T.; Lobie, P.E.; Pandey, V. Long non-coding RNAs in recurrent ovarian cancer: Theranostic perspectives. Cancer Lett. 2021, 502, 97-107. [CrossRef] [PubMed]

14. Zamaraev, A.V.; Volik, P.I.; Sukhikh, G.T.; Kopeina, G.S.; Zhivotovsky, B. Long non-coding RNAs: A view to kill ovarian cancer. Biochim. Biophys. Acta Bioenerg. 2021, 1876, 188584. [CrossRef]

15. Seborova, K.; Vaclavikova, R.; Rob, L.; Soucek, P.; Vodicka, P. Non-Coding RNAs as Biomarkers of Tumor Progression and Metastatic Spread in Epithelial Ovarian Cancer. Cancers 2021, 13, 1839. [CrossRef] [PubMed]

16. Keyvani, V.; Farshchian, M.; Esmaeili, S.-A.; Yari, H.; Moghbeli, M.; Nezhad, S.-R.K.; Abbaszadegan, M.R. Ovarian cancer stem cells and targeted therapy. J. Ovarian Res. 2019, 12, 120. [CrossRef]

17. Dubeau, L.; Drapkin, R. Coming into focus: The nonovarian origins of ovarian cancer. Ann. Oncol. 2013, 24, viii28-viii35. [CrossRef] [PubMed]

18. WHO. Female Genital Tumours; WHO: Geneva, Switzerland, 2020; ISBN 978-92-832-4504-9.

19. Hollis, R.L.; Gourley, C. Genetic and molecular changes in ovarian cancer. Cancer Biol. Med. 2016, 13, 236-247. [CrossRef]

20. Rojas, V.; Hirshfield, K.M.; Ganesan, S.; Rodriguez-Rodriguez, L. Molecular Characterization of Epithelial Ovarian Cancer: Implications for Diagnosis and Treatment. Int. J. Mol. Sci. 2016, 17, 2113. [CrossRef]

21. Peres, L.C.; Cushing-Haugen, K.L.; Köbel, M.; Harris, H.R.; Berchuck, A.; Rossing, M.A.; Schildkraut, J.M.; Doherty, J. Invasive Epithelial Ovarian Cancer Survival by Histotype and Disease Stage. J. Natl. Cancer Inst. 2019, 111, 60-68. [CrossRef]

22. Gadducci, A.; Cosio, S. Therapeutic Approach to Low-Grade Serous Ovarian Carcinoma: State of Art and Perspectives of Clinical Research. Cancers 2020, 12, 1336. [CrossRef] [PubMed]

23. Mandilaras, V.; Karakasis, K.; Clarke, B.; Oza, A.; Lheureux, S. Rare tumors in gynaecological cancers and the lack of therapeutic options and clinical trials. Expert Opin. Orphan Drugs 2016, 5, 71-83. [CrossRef]

24. Zorn, K.; Bonome, T.; Gangi, L.; Chandramouli, G.V.; Awtrey, C.S.; Gardner, G.J.; Barrett, J.C.; Boyd, J.; Birrer, M.J. Gene Expression Profiles of Serous, Endometrioid, and Clear Cell Subtypes of Ovarian and Endometrial Cancer. Clin. Cancer Res. 2005, 11, 6422-6430. [CrossRef]

25. Shibuya, Y.; Tokunaga, H.; Saito, S.; Shimokawa, K.; Katsuoka, F.; Bin, L.; Kojima, K.; Nagasaki, M.; Yamamoto, M.; Yaegashi, N.; et al. Identification of somatic genetic alterations in ovarian clear cell carcinoma with next generation sequencing. Genes Chromosom. Cancer 2018, 57, 51-60. [CrossRef]

26. Anglesio, M.S.; Kommoss, S.; Tolcher, M.C.; Clarke, B.; Galletta, L.; Porter, H.; Damaraju, S.; Fereday, S.; Winterhoff, B.J.; Kalloger, S.; et al. Molecular characterization of mucinous ovarian tumours supports a stratified treatment approach with HER2 targeting in 19\% of carcinomas. J. Pathol. 2012, 229, 111-120. [CrossRef]

27. Di Fiore, R.; Suleiman, S.; Pentimalli, F.; O’Toole, S.; O’Leary, J.; Ward, M.; Conlon, N.; Sabol, M.; Ozretić, P.; Erson-Bensan, A.; et al. Could MicroRNAs Be Useful Tools to Improve the Diagnosis and Treatment of Rare Gynecological Cancers? A Brief Overview. Int. J. Mol. Sci. 2021, 22, 3822. [CrossRef]

28. Babaier, A.; Ghatage, P. Mucinous Cancer of the Ovary: Overview and Current Status. Diagnostics 2020, 10, 52. [CrossRef]

29. Manchana, T.; Ittiwut, C.; Mutirangura, A.; Kavanagh, J.J. Targeted therapies for rare gynaecological cancers. Lancet Oncol. 2010, 11, 685-693. [CrossRef]

30. Kommoss, S.; Anglesio, M.S.; Mackenzie, R.; Yang, W.; Senz, J.; Ho, J.; Bell, L.; Lee, S.; Lorette, J.; Huntsman, D.G.; et al. FOXL2 molecular testing in ovarian neoplasms: Diagnostic approach and procedural guidelines. Mod. Pathol. 2013, 26, 860-867. [CrossRef] [PubMed]

31. Li, J.; Bao, R.; Peng, S.; Zhang, C. The molecular mechanism of ovarian granulosa cell tumors. J. Ovarian Res. 2018, 11, 1-8. [CrossRef] [PubMed]

32. Weis-Banke, S.E.; Lerdrup, M.; Kleine-Kohlbrecher, D.; Mohammad, F.; Sidoli, S.; Jensen, O.N.; Yanase, T.; Nakamura, T.; Iwase, A.; Stylianou, A.; et al. Mutant FOXL2C134W Hijacks SMAD4 and SMAD2/3 to Drive Adult Granulosa Cell Tumors. Cancer Res. 2020, 80, 3466-3479. [CrossRef] [PubMed]

33. Wang, Y.; Chen, J.; Yang, W.; Mo, F.; Senz, J.; Yap, D.; Anglesio, M.S.; Gilks, B.; Morin, G.B.; Huntsman, D.G. The Oncogenic Roles of DICER1 RNase IIIb Domain Mutations in Ovarian Sertoli-Leydig Cell Tumors. Neoplasia 2015, 17, 650-660. [CrossRef] 
34. Maoz, A.; Matsuo, K.; Ciccone, M.A.; Matsuzaki, S.; Klar, M.; Roman, L.D.; Sood, A.K.; Gershenson, D.M. Molecular Pathways and Targeted Therapies for Malignant Ovarian Germ Cell Tumors and Sex Cord-Stromal Tumors: A Contemporary Review. Cancers 2020, 12, 1398. [CrossRef] [PubMed]

35. Hollis, R.L.; Thomson, J.P.; Stanley, B.; Churchman, M.; Meynert, A.M.; Rye, T.; Bartos, C.; Iida, Y.; Croy, I.; Mackean, M.; et al. Molecular stratification of endometrioid ovarian carcinoma predicts clinical outcome. Nat. Commun. 2020, 11, 4995. [CrossRef] [PubMed]

36. Bower, M.; Fife, K.; Holden, L.; Paradinas, F.; Rustin, G.; Newlands, E. Chemotherapy for ovarian germ cell tumours. Eur. J. Cancer 1996, 32, 593-597. [CrossRef]

37. Simone, C.G.; Markham, M.J.; Dizon, D.S. Chemotherapy in ovarian germ cell tumors: A systematic review. Gynecol. Oncol. 2016, 141, 602-607. [CrossRef]

38. Goulvent, T.; Ray-Coquard, I.; Borel, S.; Haddad, V.; Devouassoux-Shisheboran, M.; Vacher-Lavenu, M.-C.; Pujade-Laurraine, E.; Savina, A.; Maillet, D.; Gillet, G.; et al. DICER1andFOXL2mutations in ovarian sex cord-stromal tumours: A GINECO Group study. Histopathology 2016, 68, 279-285. [CrossRef]

39. Ray-Coquard, I.; Weber, B.; Lotz, J.P.; Tournigand, C.; Provençal, J.; Mayeur, D.; Treilleux, I.; Paraiso, D.; Duvillard, P.; PujadeLauraine, É. Management of rare ovarian cancers: The experience of the French website «Observatory for rare malignant tumours of the ovaries» by the GINECO group: Interim analysis of the first 100 patients. Gynecol. Oncol. 2010, 119, 53-59. [CrossRef]

40. Jamieson, S.; Fuller, P. Molecular Pathogenesis of Granulosa Cell Tumors of the Ovary. Endocr. Rev. 2012, 33, 109-144. [CrossRef]

41. Nasioudis, D.; Mastroyannis, S.A.; Haggerty, A.F.; Ko, E.M.; Latif, N.A. Ovarian Sertoli-Leydig and granulosa cell tumor: Comparison of epidemiology and survival outcomes. Arch. Gynecol. Obstet. 2020, 302, 1-6. [CrossRef]

42. Aust, S.; Eberst, L.; Tredan, O.; Rousset-Jablonski, C.; Treilleux, I.; Méeus, P.; Chopin, N.; Beurrier, F.; Charreton, A.; Véronique, D.; et al. Detailed overview on rare malignant ovarian tumors. Bull. Cancer 2020, 107, 385-390. [CrossRef] [PubMed]

43. Anglesio, M.S.; Wiegand, K.C.; Melnyk, N.; Chow, C.; Salamanca, C.; Prentice, L.M.; Senz, J.; Yang, W.; Spillman, M.A.; Cochrane, D.R.; et al. Type-Specific Cell Line Models for Type-Specific Ovarian Cancer Research. PLoS ONE 2013,8, e72162. [CrossRef]

44. Domcke, S.; Sinha, R.; Levine, D.A.; Sander, C.; Schultz, N. Evaluating cell lines as tumour models by comparison of genomic profiles. Nat. Commun. 2013, 4, 2126. [CrossRef]

45. Ince, T.A.; Sousa, A.D.; Jones, M.A.; Harrell, J.C.; Agoston, E.S.; Krohn, M.; Selfors, L.; Liu, W.; Chen, K.; Yong, M.; et al. Characterization of twenty-five ovarian tumour cell lines that phenocopy primary tumours. Nat. Commun. 2015, 6, 7419. [CrossRef]

46. Barnes, B.M.; Nelson, L.; Tighe, A.; Burghel, G.J.; Lin, I.-H.; Desai, S.; McGrail, J.C.; Morgan, R.D.; Taylor, S.S. Distinct transcriptional programs stratify ovarian cancer cell lines into the five major histological subtypes. Genome Med. 2021, 13, 1-19. [CrossRef]

47. Papp, E.; Hallberg, D.; Konecny, G.E.; Bruhm, D.C.; Adleff, V.; Noë, M.; Kagiampakis, I.; Palsgrove, D.; Conklin, D.; Kinose, Y.; et al. Integrated Genomic, Epigenomic, and Expression Analyses of Ovarian Cancer Cell Lines. Cell Rep. 2018, 25, 2617-2633. [CrossRef]

48. The Cancer Genome Atlas Research Network. Integrated genomic analyses of ovarian carcinoma. Nature 2011, 474,609-615. [CrossRef]

49. Engqvist, H.; Parris, T.Z.; Biermann, J.; Rönnerman, E.W.; Larsson, P.; Sundfeldt, K.; Kovács, A.; Karlsson, P.; Helou, K. Integrative genomics approach identifies molecular features associated with early-stage ovarian carcinoma histotypes. Sci. Rep. 2020, 10, 7946. [CrossRef] [PubMed]

50. Bairoch, A. The Cellosaurus, a Cell-Line Knowledge Resource. J. Biomol. Tech. 2018, 29, 25-38. [CrossRef] [PubMed]

51. Nusinow, D.P.; Szpyt, J.; Ghandi, M.; Rose, C.M.; McDonald, E.R.; Kalocsay, M.; Jané-Valbuena, J.; Gelfand, E.; Schweppe, D.K.; Jedrychowski, M.; et al. Quantitative Proteomics of the Cancer Cell Line Encyclopedia. Cell 2020, 180, 387-402.e16. [CrossRef] [PubMed]

52. Tate, J.G.; Bamford, S.; Jubb, H.C.; Sondka, Z.; Beare, D.M.; Bindal, N.; Boutselakis, H.; Cole, C.G.; Creatore, C.; Dawson, E.; et al. COSMIC: The Catalogue of Somatic Mutations in Cancer. Nucleic Acids Res. 2019, 47, D941-D947. [CrossRef] [PubMed]

53. Mattick, J.S.; Makunin, I.V. Non-coding RNA. Hum. Mol. Genet. 2006, 15, R17-R29. [CrossRef]

54. Aprile, M.; Katopodi, V.; Leucci, E.; Costa, V. LncRNAs in Cancer: From garbage to Junk. Cancers 2020, 12, 3220. [CrossRef] [PubMed]

55. Derrien, T.; Johnson, R.; Bussotti, G.; Tanzer, A.; Djebali, S.; Tilgner, H.; Guernec, G.; Merkel, A.; Gonzalez, D.; Lagarde, J.; et al. The GENCODE v7 Catalogue of Human Long Non-Coding RNAs: Analysis of Their Structure, Evolution and Expression. Genome Res. 2012, 22, 1775-1789. [CrossRef]

56. Cheng, J.; Kapranov, P.; Drenkow, J.; Dike, S.; Brubaker, S.; Patel, S.; Long, J.; Stern, D.; Tammana, H.; Helt, G.; et al. Transcriptional Maps of 10 Human Chromosomes at 5-Nucleotide Resolution. Science 2005, 308, 1149-1154. [CrossRef] [PubMed]

57. Statello, L.; Guo, C.-J.; Chen, L.-L.; Huarte, M. Gene regulation by long non-coding RNAs and its biological functions. Nat. Rev. Mol. Cell Biol. 2021, 22, 96-118. [CrossRef]

58. Chen, L.; Zhang, Y.-H.; Pan, X.; Liu, M.; Wang, S.; Huang, T.; Cai, Y.-D. Tissue Expression Difference between mRNAs and IncRNAs. Int. J. Mol. Sci. 2018, 19, 3416. [CrossRef] 
59. Chen, X.; Sun, Z. Novel lincRNA Discovery and Tissue-Specific Gene Expression across 30 Normal Human Tissues. Genes 2021, 12, 614. [CrossRef] [PubMed]

60. Ma, L.; Bajic, V.B.; Zhang, Z. On the classification of long non-coding RNAs. RNA Biol. 2013, 10, 924-933. [CrossRef]

61. Kopp, F.; Mendell, J.T. Functional Classification and Experimental Dissection of Long Noncoding RNAs. Cell 2018, $172,393-407$. [CrossRef]

62. Balas, M.; Johnson, A.M. Exploring the mechanisms behind long noncoding RNAs and cancer. Non-Coding RNA Res. 2018, 3, 108-117. [CrossRef] [PubMed]

63. Dahariya, S.; Paddibhatla, I.; Kumar, S.; Raghuwanshi, S.; Pallepati, A.; Gutti, R.K. Long non-coding RNA: Classification, biogenesis and functions in blood cells. Mol. Immunol. 2019, 112, 82-92. [CrossRef]

64. Khandelwal, A.; Bacolla, A.; Vasquez, K.M.; Jain, A. Long non-coding RNA: A new paradigm for lung cancer. Mol. Carcinog. 2015, 54, 1235-1251. [CrossRef] [PubMed]

65. Aznaourova, M.; Schmerer, N.; Schmeck, B.; Schulte, L.N. Disease-Causing Mutations and Rearrangements in Long Non-coding RNA Gene Loci. Front. Genet. 2020, 11, 11. [CrossRef]

66. Guttman, M.; Amit, I.; Garber, M.; French, C.; Lin, M.F.; Feldser, D.; Huarte, M.; Zuk, O.; Carey, B.W.; Cassady, J.P.; et al. Chromatin signature reveals over a thousand highly conserved large non-coding RNAs in mammals. Nat. Cell Biol. 2009, 458, 223-227. [CrossRef] [PubMed]

67. Ali, T.; Grote, P. Beyond the RNA-dependent function of LncRNA genes. eLife 2020, 9, 60583. [CrossRef] [PubMed]

68. Creamer, K.M.; Lawrence, J.B. XIST RNA: A window into the broader role of RNA in nuclear chromosome architecture. Philos. Trans. R. Soc. B Biol. Sci. 2017, 372, 20160360. [CrossRef]

69. Wang, K.C.; Chang, H.Y. Molecular Mechanisms of Long Noncoding RNAs. Mol. Cell 2011, 43, 904-914. [CrossRef]

70. Ebert, M.S.; Sharp, P.A. Emerging Roles for Natural MicroRNA Sponges. Curr. Biol. 2010, 20, R858-R861. [CrossRef]

71. Xing, J.; Liu, H.; Jiang, W.; Wang, L. LncRNA-Encoded Peptide: Functions and Predicting Methods. Front. Oncol. 2021, 10. [CrossRef]

72. Huang, Y.; Zheng, Y.; Jia, L.; Li, W. Long Noncoding RNA H19 Promotes Osteoblast Differentiation Via TGF- $\beta 1 /$ Smad3/HDAC Signaling Pathway by Deriving miR-675. Stem Cells 2015, 33, 3481-3492. [CrossRef]

73. Bocchetti, M.; Scrima, M.; Melisi, F.; Luce, A.; Sperlongano, R.; Caraglia, M.; Zappavigna, S.; Cossu, A. LncRNAs and Immunity: Coding the Immune System with Noncoding Oligonucleotides. Int. J. Mol. Sci. 2021, 22, 1741. [CrossRef] [PubMed]

74. Aillaud, M.; Schulte, L.N. Emerging Roles of Long Noncoding RNAs in the Cytoplasmic Milieu. Non-Coding RNA 2020, 6, 44. [CrossRef] [PubMed]

75. Gusic, M.; Prokisch, H. ncRNAs: New Players in Mitochondrial Health and Disease? Front. Genet. 2020, 11, 95. [CrossRef] [PubMed]

76. Arcucci, V.; Stacker, S.; Achen, M. Control of Gene Expression by Exosome-Derived Non-Coding RNAs in Cancer Angiogenesis and Lymphangiogenesis. Biomolecules 2021, 11, 249. [CrossRef]

77. Tassinari, M.; Gandellini, P. Noncoding RNAs in the Interplay between Tumor Cells and Cancer-Associated Fibroblasts: Signals to Catch and Targets to Hit. Cancers 2021, 13, 709. [CrossRef]

78. Schmitt, A.M.; Chang, H.Y. Long Noncoding RNAs in Cancer Pathways. Cancer Cell 2016, 29, 452-463. [CrossRef]

79. Carlevaro-Fita, J.; Lanzós, A.; Feuerbach, L.; Hong, C.; Mas-Ponte, D.; Pedersen, J.S.; PCAWG Drivers and Functional Interpretation Group; Johnson, R.; PCAWG Consortium Cancer. LncRNA Census reveals evidence for deep functional conservation of long noncoding RNAs in tumorigenesis. Commun. Biol. 2020, 3, 56. [CrossRef]

80. Liu, S.J.; Dang, H.X.; Lim, D.A.; Feng, F.Y.; Maher, C.A. Long noncoding RNAs in cancer metastasis. Nat. Rev. Cancer 2021, 21, 446-460. [CrossRef]

81. May, J.M.; Bylicky, M.; Chopra, S.; Coleman, C.N.; Aryankalayil, M.J. Long and short non-coding RNA and radiation response: A review. Transl. Res. 2021, 233, 162-179. [CrossRef]

82. McCabe, E.M.; Rasmussen, T.P. IncRNA involvement in cancer stem cell function and epithelial-mesenchymal transitions. Semin. Cancer Biol. 2020. [CrossRef]

83. Zeng, S.; Liu, S.; Feng, J.; Gao, J.; Xue, F. Upregulation of lncRNA AB073614 functions as a predictor of epithelial ovarian cancer prognosis and promotes tumor growth in vitro and in vivo. Cancer Biomark. 2019, 24, 421-428. [CrossRef] [PubMed]

84. Sun, T.; Yang, P.; Gao, Y. Long non-coding RNA EPB41L4A-AS2 suppresses progression of ovarian cancer by sequestering microRNA-103a to upregulate transcription factor RUNX1T1. Exp. Physiol. 2019, 105, 75-87. [CrossRef] [PubMed]

85. Zhang, J.; Yang, Z.; Huang, Y.; Wang, K.; Xie, Y.; Yang, N. LncRNA GAS5 inhibits the proliferation and invasion of ovarian clear cell carcinoma via the miR -31-5p/ ARID1A axis. Kaohsiung J. Med Sci. 2021. [CrossRef] [PubMed]

86. Gong, M.; Luo, C.; Meng, H.; Li, S.; Nie, S.; Jiang, Y.; Wan, Y.; Li, H.; Cheng, W. Upregulated LINC00565 Accelerates Ovarian Cancer Progression By Targeting GAS6. OncoTargets Ther. 2019, 12, 10011-10022. [CrossRef] [PubMed]

87. Li, R.; Wang, Y.; Xu, Y.; He, X.; Li, Y. Silencing the long noncoding RNA, TINCR, a molecular sponge of miR-335, inhibits the malignant phenotype of epithelial ovarian cancer via FGF2 suppression. Int. J. Oncol. 2019, 55, 1110-1124. [CrossRef] [PubMed]

88. Wu, W.; Gao, H.; Li, X.; Zhu, Y.; Peng, S.; Yu, J.; Zhan, G.; Wang, J.; Liu, N.; Guo, X. LncRNA TPT1-AS1 promotes tumorigenesis and metastasis in epithelial ovarian cancer by inducingTPT1 expression. Cancer Sci. 2019, 110, 1587-1598. [CrossRef]

89. Lv, Y.; Li, H.; Li, F.; Liu, P.; Zhao, X. Long Noncoding RNA MNX1-AS1 Knockdown Inhibits Cell Proliferation and Migration in Ovarian Cancer. Cancer Biother. Radiopharm. 2017, 32, 91-99. [CrossRef] [PubMed] 
90. Li, H.; Liu, C.; Lu, Z.; Chen, L.; Wang, J.; Li, Y.; Ma, H. Upregulation of the long non-coding RNA SPRY4-IT1 indicates a poor prognosis and promotes tumorigenesis in ovarian cancer. Biomed. Pharmacother. 2017, 88, 529-534. [CrossRef] [PubMed]

91. Zhang, M.; Liu, S.; Fu, C.; Wang, X.; Liu, G.; Dai, C.; Gong, Z.; Xu, H.; Fu, Z.; Xu, P.; et al. LncRNA KB-1471A8.2 Overexpression Suppresses Cell Proliferation and Migration and Antagonizes the Paclitaxel Resistance of Ovarian Cancer Cells. Cancer Biother. Radiopharm. 2019, 34, 316-324. [CrossRef]

92. Shi, Y.; Gao, S.; Zheng, Y.; Yao, M.; Ruan, F. LncRNA CASC15 Functions As An Unfavorable Predictor Of Ovarian Cancer Prognosis And Inhibits Tumor Progression Through Regulation Of miR-221/ARID1A Axis. OncoTargets Ther. 2019, 12, 8725-8736. [CrossRef]

93. Yuan, D.; Zhang, X.; Zhao, Y.; Qian, H.; Wang, H.; He, C.; Liu, X.; Guo, T.; Lin, M.; Yu, H.; et al. Role of lncRNA-ATB in ovarian cancer and its mechanisms of action. Exp. Ther. Med. 2019, 19, 965-971. [CrossRef]

94. Li, J.; Yang, C.; Li, Y.; Chen, A.; Li, L.; You, Z. LncRNA GAS5 suppresses ovarian cancer by inducing inflammasome formation. Biosci. Rep. 2018, 38, 20171150. [CrossRef]

95. Xiu, Y.-L.; Sun, K.-X.; Chen, X.; Chen, S.; Zhao, Y.; Guo, Q.-G.; Zong, Z.-H. Upregulation of the lncRNA Meg3 induces autophagy to inhibit tumorigenesis and progression of epithelial ovarian carcinoma by regulating activity of ATG3. Oncotarget 2017, 8 , 31714-31725. [CrossRef]

96. Hu, J.; Zhang, L.; Mei, Z.; Jiang, Y.; Yi, Y.; Liu, L.; Meng, Y.; Zhou, L.; Zeng, J.; Wu, H.; et al. Interaction of E3 Ubiquitin Ligase MARCH7 with Long Noncoding RNA MALAT1 and Autophagy-Related Protein ATG7 Promotes Autophagy and Invasion in Ovarian Cancer. Cell. Physiol. Biochem. 2018, 47, 654-666. [CrossRef]

97. Yu, Y.; Zhang, X.; Tian, H.; Zhang, Z.; Tian, Y. Knockdown of long non-coding RNA HOTAIR increases cisplatin sensitivity in ovarian cancer by inhibiting cisplatin-induced autophagy. Off. J. Balk. Union Oncol. 2018, 23, 1396-1401.

98. Chen, S.; Wu, D.-D.; Sang, X.-B.; Wang, L.-L.; Zong, Z.-H.; Sun, K.-X.; Liu, B.-L.; Zhao, Y. The lncRNA HULC functions as an oncogene by targeting ATG7 and ITGB1 in epithelial ovarian carcinoma. Cell Death Dis. 2017, 8, e3118. [CrossRef]

99. Zou, S.-H.; Du, X.; Sun, F.-D.; Wang, P.-C.; Li, M. Cisplatin suppresses tumor proliferation by inhibiting autophagy in ovarian cancer via long non-coding RNA RP11-135L22.1. Eur. Rev. Med. Pharmacol. Sci. 2018, 22, 928-935. [CrossRef] [PubMed]

100. Mirzaei, H.; Hamblin, M.R. Regulation of Glycolysis by Non-coding RNAs in Cancer: Switching on the Warburg Effect. Mol. Ther.-Oncolytics 2020, 19, 218-239. [CrossRef]

101. Liu, Y.; He, X.; Chen, Y.; Cao, D. Long non-coding RNA LINC00504 regulates the Warburg effect in ovarian cancer through inhibition of miR-1244. Mol. Cell. Biochem. 2020, 464, 39-50. [CrossRef] [PubMed]

102. Rupaimoole, R.; Lee, J.; Haemmerle, M.; Ling, H.; Previs, R.A.; Pradeep, S.; Wu, S.; Ivan, C.; Ferracin, M.; Dennison, J.B.; et al Long Noncoding RNA Ceruloplasmin Promotes Cancer Growth by Altering Glycolysis. Cell Rep. 2015, 13, 2395-2402. [CrossRef] [PubMed]

103. Zhao, L.; Ji, G.; Le, X.; Wang, C.; Xu, L.; Feng, M.; Zhang, Y.; Yang, H.; Xuan, Y.; Yang, Y.; et al. Long Noncoding RNA LINC00092 Acts in Cancer-Associated Fibroblasts to Drive Glycolysis and Progression of Ovarian Cancer. Cancer Res. 2017, 77, 1369-1382. [CrossRef]

104. Zheng, X.; Zhou, Y.; Chen, W.; Chen, L.; Lu, J.; He, F.; Li, X.; Zhao, L. Ginsenoside 20(S)-Rg3 Prevents PKM2-Targeting miR-324-5p from H19 Sponging to Antagonize the Warburg Effect in Ovarian Cancer Cells. Cell. Physiol. Biochem. 2018, 51, 1340-1353. [CrossRef]

105. Qiu, J.-J.; Lin, X.-J.; Tang, X.-Y.; Zheng, T.-T.; Lin, Y.-Y.; Hua, K.-Q. Exosomal Metastasis-Associated Lung Adenocarcinoma Transcript 1 Promotes Angiogenesis and Predicts Poor Prognosis in Epithelial Ovarian Cancer. Int. J. Biol. Sci. 2018, 14, 1960-1973. [CrossRef] [PubMed]

106. Lin, X.; Yang, F.; Qi, X.; Li, Q.; Wang, D.; Yi, T.; Yin, R.; Zhao, X.; Zhong, X.; Bian, C. LncRNA DANCR promotes tumor growth and angiogenesis in ovarian cancer through direct targeting of miR-145. Mol. Carcinog. 2019, 58, 2286-2296. [CrossRef] [PubMed]

107. Liu, Y.; Lin, J.; Pan, J.; Qing, Q.; Li, D.; Liao, J.; Sun, C.; Zhou, H. LncRNA HNF1A-AS1 Promotes Ovarian Cancer Growth by Countering MiR-214-Mediated Suppression of the Sema 4D/Plexin B1 Pathway; Social Science Research Network: Rochester, NY, USA, 2019.

108. Wu, M.; Fu, P.; Qu, L.; Liu, J.; Lin, A. Long Noncoding RNAs, New Critical Regulators in Cancer Immunity. Front. Oncol. 2020, 10, 550987. [CrossRef] [PubMed]

109. Shang, A.; Wang, W.; Gu, C.; Chen, C.; Zeng, B.; Yang, Y.; Ji, P.; Sun, J.; Wu, J.; Lu, W.; et al. Long non-coding RNA HOTTIP enhances IL-6 expression to potentiate immune escape of ovarian cancer cells by upregulating the expression of PD-L1 in neutrophils. J. Exp. Clin. Cancer Res. 2019, 38, 411. [CrossRef] [PubMed]

110. Garg, M. Epithelial-mesenchymal transition-activating transcription factors-Multifunctional regulators in cancer. World J. Stem Cells 2013, 5, 188-195. [CrossRef] [PubMed]

111. Vafaee, F.; Colvin, E.K.; Mok, S.C.; Howell, V.M.; Samimi, G. Functional prediction of long non-coding RNAs in ovarian cancer-associated fibroblasts indicate a potential role in metastasis. Sci. Rep. 2017, 7, 10374. [CrossRef] [PubMed]

112. Chen, L.; Liu, S.; Tao, Y. Regulating tumor suppressor genes: Post-translational modifications. Signal Transduct. Target. Ther. 2020, 5, 1-25. [CrossRef]

113. Zhang, H.; Han, W. Protein Post-translational Modifications in Head and Neck Cancer. Front. Oncol. 2020, 10, 571944. [CrossRef]

114. Yao, R.-W.; Wang, Y.; Chen, L.-L. Cellular functions of long noncoding RNAs. Nat. Cell Biol. 2019, 21, 542-551. [CrossRef]

115. Pérez-Cadahía, B.; Drobic, B.; Khan, P.; Shivashankar, C.C.; Davie, J. Current understanding and importance of histone phosphorylation in regulating chromatin biology. Curr. Opin. Drug Discov. Dev. 2010, 13, 613-622. 
116. Esteller, M. Epigenetics in Cancer. N. Engl. J. Med. 2008, 358, 1148-1159. [CrossRef] [PubMed]

117. Yang, Q.; Yang, Y.; Zhou, N.; Tang, K.; Lau, W.B.; Lau, B.; Wang, W.; Xu, L.; Yang, Z.; Huang, S.; et al. Epigenetics in ovarian cancer: Premise, properties, and perspectives. Mol. Cancer 2018, 17, 109. [CrossRef]

118. Zhang, X.; Wang, W.; Zhu, W.; Dong, J.; Cheng, Y.; Yin, Z.; Shen, F. Mechanisms and Functions of Long Non-Coding RNAs at Multiple Regulatory Levels. Int. J. Mol. Sci. 2019, 20, 5573. [CrossRef] [PubMed]

119. Jain, A.K.; Xi, Y.; McCarthy, R.; Allton, K.; Akdemir, K.C.; Patel, L.; Aronow, B.; Lin, C.; Li, W.; Yang, L.; et al. LncPRESS1 Is a p53-Regulated LncRNA that Safeguards Pluripotency by Disrupting SIRT6-Mediated De-acetylation of Histone H3K56. Mol. Cell 2016, 64, 967-981. [CrossRef] [PubMed]

120. Sun, T.-T.; He, J.; Liang, Q.; Ren, L.-L.; Yan, T.-T.; Yu, T.-C.; Tang, J.; Bao, Y.-J.; Hu, Y.; Lin, Y.; et al. LncRNA GClnc1 Promotes Gastric Carcinogenesis and May Act as a Modular Scaffold of WDR5 and KAT2A Complexes to Specify the Histone Modification Pattern. Cancer Discov. 2016, 6, 784-801. [CrossRef] [PubMed]

121. Huang, K.-L.; Scott, A.D.; Zhou, D.C.; Wang, L.-B.; Weerasinghe, A.; Elmas, A.; Liu, R.; Wu, Y.; Wendl, M.C.; Wyczalkowski, M.A.; et al. Spatially interacting phosphorylation sites and mutations in cancer. Nat. Commun. 2021, 12, 1-13. [CrossRef]

122. Mereiter, S.; Balmaña, M.; Campos, D.; Gomes, J.; Reis, C.A. Glycosylation in the Era of Cancer-Targeted Therapy: Where Are We Heading? Cancer Cell 2019, 36, 6-16. [CrossRef] [PubMed]

123. Abbott, K.L.; Lim, J.-M.; Wells, L.; Benigno, B.B.; McDonald, J.F.; Pierce, M. Identification of candidate biomarkers with cancerspecific glycosylation in the tissue and serum of endometrioid ovarian cancer patients by glycoproteomic analysis. Proteomics 2010, 10, 470-481. [CrossRef] [PubMed]

124. Hua, S.; Williams, C.C.; Dimapasoc, L.M.; Ro, G.S.; Ozcan, S.; Miyamoto, S.; Lebrilla, C.B.; An, H.J.; Leiserowitz, G.S. Isomerspecific chromatographic profiling yields highly sensitive and specific potential N-glycan biomarkers for epithelial ovarian cancer. J. Chromatogr. A 2013, 1279, 58-67. [CrossRef]

125. Pinho, S.S.; Reis, C.A. Glycosylation in cancer: Mechanisms and clinical implications. Nat. Rev. Cancer 2015, 15, 540-555. [CrossRef]

126. Saldova, R.F.; Wormald, M.; Dwek, R.A.; Rudd, P.M. Glycosylation Changes on Serum Glycoproteins in Ovarian Cancer May Contribute to Disease Pathogenesis. Dis. Markers 2008, 25, 219-232. [CrossRef] [PubMed]

127. Liu, Y.; Ferguson, J.F.; Xue, C.; Ballantyne, R.L.; Silverman, I.; Gosai, S.J.; Serfecz, J.; Morley, M.P.; Gregory, B.D.; Li, M.; et al. Tissue-Specific RNA-Seq in Human Evoked Inflammation Identifies Blood and Adipose LincRNA Signatures of Cardiometabolic Diseases. Arter. Thromb. Vasc. Biol. 2014, 34, 902-912. [CrossRef] [PubMed]

128. Lanzillotti, C.; De Mattei, M.; Mazziotta, C.; Taraballi, F.; Rotondo, J.C.; Tognon, M.; Martini, F. Long Non-coding RNAs and MicroRNAs Interplay in Osteogenic Differentiation of Mesenchymal Stem Cells. Front. Cell Dev. Biol. 2021, 9, 646032. [CrossRef] [PubMed]

129. Nombela-Arrieta, C.; Ritz, J.; Silberstein, L.E. The elusive nature and function of mesenchymal stem cells. Nat. Rev. Mol. Cell Biol. 2011, 12, 126-131. [CrossRef]

130. Bhaskar, B.; Mekala, N.; Baadhe, R.R.; Rao, P. Role of Signaling Pathways in Mesenchymal Stem Cell Differentiation. Curr. Stem Cell Res. Ther. 2014, 9, 508-512. [CrossRef] [PubMed]

131. Sikora, M.; Marycz, K.; Smieszek, A. Small and Long Non-coding RNAs as Functional Regulators of Bone Homeostasis, Acting Alone or Cooperatively. Mol. Ther.-Nucleic Acids 2020, 21, 792-803. [CrossRef]

132. Wagner, E.; Luther, G.; Zhu, G.; Luo, Q.; Shi, Q.; Kim, S.H.; Gao, J.; Huang, E.; Gao, Y.; Yang, K.; et al. Defective Osteogenic Differentiation in the Development of Osteosarcoma. Sarcoma 2011, 2011, 325238. [CrossRef]

133. Qiao, L.; Xu, Z.-L.; Zhao, T.-J.; Ye, L.-H.; Zhang, X.-D. Dkk-1 secreted by mesenchymal stem cells inhibits growth of breast cancer cells via depression of Wnt signalling. Cancer Lett. 2008, 269, 67-77. [CrossRef]

134. Muehlberg, F.L.; Song, Y.-H.; Krohn, A.; Pinilla, S.P.; Droll, L.H.; Leng, X.; Seidensticker, M.; Ricke, J.; Altman, A.M.; Devarajan, E.; et al. Tissue-resident stem cells promote breast cancer growth and metastasis. Carcinogenesis 2009, 30, 589-597. [CrossRef]

135. McLean, K.; Gong, Y.; Choi, Y.; Deng, N.; Yang, K.; Bai, S.; Cabrera, L.; Keller, E.; McCauley, L.; Cho, K.; et al. Human ovarian carcinoma-associated mesenchymal stem cells regulate cancer stem cells and tumorigenesis via altered BMP production. J. Clin. Investig. 2011, 121, 3206-3219. [CrossRef] [PubMed]

136. Gauthaman, K.; Yee, F.C.; Cheyyatraivendran, S.; Biswas, A.; Choolani, M.; Bongso, A. Human umbilical cord wharton's jelly stem cell (hWJSC) extracts inhibit cancer cell growth in vitro. J. Cell. Biochem. 2012, 113, 2027-2039. [CrossRef]

137. Zhu, P.; Chen, M.; Wang, L.; Ning, Y.; Liang, J.; Zhang, H.; Xu, C.; Chen, S.; Yao, L. Systemic mesenchymal stem cells reduce growth rate of cisplatin-resistant ovarian cancer. Int. J. Clin. Exp. Pathol. 2013, 6, 2506-2514. [PubMed]

138. Bu, S.; Wang, Q.; Zhang, Q.; Sun, J.; He, B.; Xiang, C.; Liu, Z.; Lai, D. Human endometrial mesenchymal stem cells exhibit intrinsic anti-tumor properties on human epithelial ovarian cancer cells. Sci. Rep. 2016, 6, 37019. [CrossRef]

139. Yan, X.; Hu, Z.; Feng, Y.; Hu, X.; Yuan, J.; Zhao, S.D.; Zhang, Y.; Yang, L.; Shan, W.; He, Q.; et al. Comprehensive Genomic Characterization of Long Non-coding RNAs across Human Cancers. Cancer Cell 2015, 28, 529-540. [CrossRef]

140. Akrami, R.; Jacobsen, A.; Hoell, J.; Schultz, N.; Sander, C.; Larsson, E. Comprehensive Analysis of Long Non-Coding RNAs in Ovarian Cancer Reveals Global Patterns and Targeted DNA Amplification. PLoS ONE 2013, 8, e80306. [CrossRef] [PubMed] 
141. Yang, K.; Hou, Y.; Li, K.; Li, Z.; Wang, W.; Xie, H.; Rong, Z.; Lou, G. Identification of a six-lncRNA signature associated with recurrence of ovarian cancer. Sci. Rep. 2017, 7, 752. [CrossRef] [PubMed]

142. Kim, H.T.; Choi, B.H.; Niikawa, N.; Lee, T.S.; Chang, S.I. Frequent loss of imprinting of the H19 and IGF-II genes in ovarian tumors. Am. J. Med. Genet. 1998, 80, 391-395. [CrossRef]

143. Zhu, Z.; Song, L.; He, J.; Sun, Y.; Liu, X.; Zou, X. Ectopic expressed long non-coding RNA H19 contributes to malignant cell behavior of ovarian cancer. Int. J. Clin. Exp. Pathol. 2015, 8, 10082-10091.

144. Li, J.; Huang, Y.; Deng, X.; Luo, M.; Wang, X.; Hu, H.; Liu, C.; Zhong, M. Long noncoding RNA H19 promotes transforming growth factor- $\beta$-induced epithelial-mesenchymal transition by acting as a competing endogenous RNA of miR-370-3p in ovarian cancer cells. OncoTargets Ther. 2018, 11, 427-440. [CrossRef] [PubMed]

145. Yan, L.; Zhou, J.; Gao, Y.; Ghazal, S.; Lu, L.; Bellone, S.; Yang, Y.; Liu, N.; Zhao, X.; Santin, A.D.; et al. Regulation of tumor cell migration and invasion by the H19/let-7 axis is antagonized by metformin-induced DNA methylation. Oncogene 2015, 34, 3076-3084. [CrossRef]

146. Wu, Y.; Zhou, Y.; He, J.; Sun, H.; Jin, Z. Long non-coding RNA H19 mediates ovarian cancer cell cisplatin-resistance and migration during EMT. Int. J. Clin. Exp. Pathol. 2019, 12, 2506-2515.

147. Sajadpoor, Z.; Amini-Farsani, Z.; Teimori, H.; Shamsara, M.; Sangtarash, M.H.; Ghasemi-Dehkordi, P.; Yadollahi, F. Valproic Acid Promotes Apoptosis and Cisplatin Sensitivity Through Downregulation of H19 Noncoding RNA in Ovarian A2780 Cells. Appl. Biochem. Biotechnol. 2018, 185, 1132-1144. [CrossRef]

148. Zheng, Z.-G.; Xu, H.; Suo, S.-S.; Xu, X.-L.; Ni, M.-W.; Gu, L.-H.; Chen, W.; Wang, L.-Y.; Zhao, Y.; Tian, B.; et al. The Essential Role of H19 Contributing to Cisplatin Resistance by Regulating Glutathione Metabolism in High-Grade Serous Ovarian Cancer. Sci. Rep. 2016, 6, 26093. [CrossRef] [PubMed]

149. Zeng, Y.; Li, T.-L.; Zhang, H.-B.; Deng, J.-L.; Zhang, R.; Sun, H.; Wan, Z.-R.; Liu, Y.-Z.; Zhu, Y.-S.; Wang, G. Polymorphisms in IGF2/H19 gene locus are associated with platinum-based chemotherapeutic response in Chinese patients with epithelial ovarian cancer. Pharmacogenomics 2019, 20, 179-188. [CrossRef] [PubMed]

150. Rachmilewitz, J.; Elkin, M.; Rosensaft, J.; Gelman-Kohan, Z.; Ariel, I.; Lustig, O.; Schneider, T.; Goshen, R.; Biran, H.; De Groot, N. H19 expression and tumorigenicity of choriocarcinoma derived cell lines. Oncogene 1995, 11, 863-870.

151. Ross, J.A.; Schmidt, P.T.; Perentesis, J.P.; Davies, S.M. Genomic Imprinting of H19 and Insulin-like Growth Factor-2 in Pediatric Germ Cell Tumors. Cancer 1999, 85, 1389-1394. [CrossRef]

152. Schneider, D.T.; Schuster, A.; Fritsch, M.K.; Hu, J.; Olson, T.; Lauer, S.; Göbel, U.; Perlman, E. Multipoint imprinting analysis indicates a common precursor cell for gonadal and nongonadal pediatric germ cell tumors. Cancer Res. 2001, 61, 7268-7276.

153. Sievers, S.; Alemazkour, K.; Zahn, S.; Perlman, E.; Gillis, A.J.M.; Looijenga, L.; Göbel, U.; Schneider, D.T. IGF2/H19 imprinting analysis of human germ cell tumors (GCTs) using the methylation-sensitive single-nucleotide primer extension method reflects the origin of GCTs in different stages of primordial germ cell development. Genes Chromosom. Cancer 2005, 44, 256-264. [CrossRef]

154. Miura, K.; Obama, M.; Yun, K.; Masuzaki, H.; Ikeda, Y.; Yoshimura, S.; Akashi, T.; Niikawa, N.; Ishimaru, T.; Jinno, Y. Meth-ylation Imprinting of H19 and SNRPN Genes in Human Benign Ovarian Teratomas. Am. J. Hum. Genet. 1999, 65, 1359-1367. [CrossRef]

155. Sun, X.; Yan, X.; Liu, K.; Wu, M.; Li, Z.; Wang, Y.; Zhong, X.; Qin, L.; Huang, C.; Wei, X. lncRNA H19 acts as a ceRNA to regulate the expression of CTGF by targeting miR-19b in polycystic ovary syndrome. Braz. J. Med Biol. Res. 2020, 53, e9266. [CrossRef]

156. Cantile, M.; Di Bonito, M.; De Bellis, M.T.; Botti, G. Functional Interaction among lncRNA HOTAIR and MicroRNAs in Cancer and Other Human Diseases. Cancers 2021, 13, 570. [CrossRef]

157. Tsai, M.-C.; Manor, O.; Wan, Y.; Mosammaparast, N.; Wang, J.K.; Lan, F.; Shi, Y.; Segal, E.; Chang, H.Y. Long Noncoding RNA as Modular Scaffold of Histone Modification Complexes. Science 2010, 329, 689-693. [CrossRef]

158. Qiu, J.-J.; Wang, Y.; Ding, J.-X.; Jin, H.-Y.; Yang, G.; Hua, K.-Q. The long non-coding RNA HOTAIR promotes the proliferation of serous ovarian cancer cells through the regulation of cell cycle arrest and apoptosis. Exp. Cell Res. 2015, 333, 238-248. [CrossRef]

159. Wang, Y.; Wang, H.; Song, T.; Zou, Y.; Jiang, J.; Fang, L.; Li, P. HOTAIR is a potential target for the treatment of cisplatin-resistant ovarian cancer. Mol. Med. Rep. 2015, 12, 2211-2216. [CrossRef] [PubMed]

160. Zhang, Y.; Guo, J.; Cai, E.; Cai, J.; Wen, Y.; Lu, S.; Li, X.; Han, Q.; Jiang, J.; Li, T.; et al. HOTAIR maintains the stemness of ovarian cancer stem cells via the miR-206/TBX3 axis. Exp. Cell Res. 2020, 395, 112218. [CrossRef] [PubMed]

161. Bhan, A.; Hussain, I.; Ansari, K.; Kasiri, S.; Bashyal, A.; Mandal, S.S. Antisense Transcript Long Noncoding RNA (lncRNA) HOTAIR is Transcriptionally Induced by Estradiol. J. Mol. Biol. 2013, 425, 3707-3722. [CrossRef] [PubMed]

162. Huang, L.; Liao, L.-M.; Liu, A.-W.; Wu, J.-B.; Cheng, X.-L.; Lin, J.-X.; Zheng, M. Overexpression of long noncoding RNA HOTAIR predicts a poor prognosis in patients with cervical cancer. Arch. Gynecol. Obstet. 2014, 290, 717-723. [CrossRef] [PubMed]

163. Luo, P.; Liu, X.-F.; Wang, Y.-C.; Li, N.-D.; Liao, S.-J.; Yu, M.; Liang, C.-Z.; Tu, J.-C. Prognostic value of abnormally expressed IncRNAs in ovarian carcinoma: A systematic review and meta-analysis. Oncotarget 2017, 8, 23927-23936. [CrossRef]

164. Qiu, J.-J.; Lin, Y.-Y.; Ye, L.-C.; Ding, J.-X.; Feng, W.-W.; Jin, H.-Y.; Zhang, Y.; Li, Q.; Hua, K.-Q. Overexpression of long non-coding RNA HOTAIR predicts poor patient prognosis and promotes tumor metastasis in epithelial ovarian cancer. Gynecol. Oncol. 2014, 134, 121-128. [CrossRef] [PubMed]

165. Li, J.; Wen, W.; Zhao, S.; Wang, J.; Chen, J.; Wang, Y.; Zhang, Q. Prognostic role of HOTAIR in four estrogen-dependent malignant tumors: A meta-analysis. OncoTargets Ther. 2015, 8, 1471-1482. [CrossRef]

166. Saeedi, N.; Ghorbian, S. Analysis of clinical important of LncRNA-HOTAIR gene variations and ovarian cancer susceptibility. Mol. Biol. Rep. 2020, 47, 7421-7427. [CrossRef] 
167. Wu, H.; Shang, X.; Shi, Y.; Yang, Z.; Zhao, J.; Yang, M.; Li, Y.; Xu, S. Genetic variants of lncRNA HOTAIR and risk of epithelial ovarian cancer among Chinese women. Oncotarget 2016, 7, 41047-41052. [CrossRef] [PubMed]

168. Liu, S.; Lei, H.; Luo, F.; Li, Y.; Xie, L. The effect of lncRNA HOTAIR on chemoresistance of ovarian cancer through regulation of HOXA. Biol. Chem. 2018, 399, 485-497. [CrossRef]

169. Teschendorff, A.E.; Lee, S.-H.; Jones, A.; Fiegl, H.; Kalwa, M.; Wagner, W.; Chindera, K.; Evans, I.; Dubeau, L.; Orjalo, A.; et al. HOTAIR and its surrogate DNA methylation signature indicate carboplatin resistance in ovarian cancer. Genome Med. 2015, 7, 108. [CrossRef] [PubMed]

170. Özeş, A.R.; Wang, Y.; Zong, X.; Fang, F.; Pilrose, J.; Nephew, K.P. Therapeutic targeting using tumor specific peptides inhibits long non-coding RNA HOTAIR activity in ovarian and breast cancer. Sci. Rep. 2017, 7, 894. [CrossRef] [PubMed]

171. Islam, N.; Moriam, S.; Umer, M.; Phan, H.-P.; Salomon, C.; Kline, R.; Nguyen, N.-T.; Shiddiky, M.J.A. Naked-eye and electrochemical detection of isothermally amplified HOTAIR long non-coding RNA. Analyst 2018, 143, 3021-3028. [CrossRef] [PubMed]

172. Soda, N.; Umer, M.; Kashaninejad, N.; Kasetsirikul, S.; Kline, R.; Salomon, C.; Nguyen, N.-T.; Shiddiky, M.J.A. PCR-Free Detection of Long Non-Coding HOTAIR RNA in Ovarian Cancer Cell Lines and Plasma Samples. Cancers 2020, 12, 2233. [CrossRef]

173. Zhu, K.; Ren, Q.; Zhao, Y. lncRNA MALAT1 overexpression promotes proliferation, migration and invasion of gastric cancer by activating the PI3K/AKT pathway. Oncol. Lett. 2019, 17, 5335-5342. [CrossRef]

174. Pang, E.-J.; Yang, R.; Fu, X.-B.; Liu, Y.-F. Overexpression of long non-coding RNA MALAT1 is correlated with clinical progression and unfavorable prognosis in pancreatic cancer. Tumor Biol. 2015, 36, 2403-2407. [CrossRef]

175. Wang, Y.; Xue, D.; Li, Y.; Pan, X.; Zhang, X.; Kuang, B.; Zhou, M.; Li, X.; Xiong, W.; Li, G.; et al. The Long Noncoding RNA MALAT1 is A Novel Biomarker in Various Cancers: A Meta-analysis Based on the GEO Database and Literature. J. Cancer 2016, 7, 991-1001. [CrossRef] [PubMed]

176. Chen, Q.; Su, Y.; He, X.; Zhao, W.; Wu, C.; Zhang, W.; Si, X.; Dong, B.; Zhao, L.; Gao, Y.; et al. Plasma long non-coding RNA MALAT1 is associated with distant metastasis in patients with epithelial ovarian cancer. Oncol. Lett. 2016, 12, 1361-1366. [CrossRef] [PubMed]

177. Zhou, Y.; Xu, X.; Lv, H.; Wen, Q.; Li, J.; Tan, L.; Li, J.; Sheng, X. The Long Noncoding RNA MALAT-1 Is Highly Expressed in Ovarian Cancer and Induces Cell Growth and Migration. PLoS ONE 2016, 11, e0155250. [CrossRef]

178. Zou, A.; Liu, R.; Wu, X. Long non-coding RNA MALAT1 is up-regulated in ovarian cancer tissue and promotes SK-OV-3 cell proliferation and invasion. Neoplasma 2016, 63, 865-872. [CrossRef]

179. Pei, C.; Gong, X.; Zhang, Y. LncRNA MALAT-1 promotes growth and metastasis of epithelial ovarian cancer via sponging microrna. Am. J. Transl. Res. 2020, 12, 6977-6987. [PubMed]

180. Lei, R.; Xue, M.; Zhang, L.; Lin, Z. Long noncoding RNA MALAT1-regulated microRNA 506 modulates ovarian cancer growth by targeting iASPP. OncoTargets Ther. 2016, 10, 35-46. [CrossRef]

181. Pa, M.; Naizaer, G.; Seyiti, A.; Kuerbang, G. Long Noncoding RNA MALAT1 Functions as a Sponge of MiR-200c in Ovarian Cancer. Oncol. Res. 2017. [CrossRef]

182. Lin, Q.; Guan, W.; Ren, W.; Zhang, L.; Zhang, J.; Xu, G. MALAT1 affects ovarian cancer cell behavior and patient survival. Oncol. Rep. 2018, 39, 2644-2652. [CrossRef]

183. Tao, F.; Tian, X.; Ruan, S.; Shen, M.; Zhang, Z. miR-211 sponges lncRNA MALAT1 to suppress tumor growth and progression through inhibiting PHF19 in ovarian carcinoma. FASEB J. 2018, 32, 6330-6343. [CrossRef]

184. Sun, Q.; Li, Q.; Xie, F. LncRNA-MALAT1 regulates proliferation and apoptosis of ovarian cancer cells by targeting miR-503-5p. OncoTargets Ther. 2019, 12, 6297-6307. [CrossRef]

185. Gordon, M.A.; Babbs, B.; Cochrane, D.R.; Bitler, B.; Richer, J.K. The long non-coding RNA MALAT1 promotes ovarian cancer progression by regulating RBFOX2-mediated alternative splicing. Mol. Carcinog. 2019, 58, 196-205. [CrossRef]

186. Jin, Y.; Feng, S.-J.; Qiu, S.; Shao, N.; Zheng, J.-H. LncRNA MALAT1 promotes proliferation and metastasis in epithelial ovarian cancer via the PI3K-AKT pathway. Eur. Rev. Med Pharmacol. Sci. 2017, 21, 3176-3184. [PubMed]

187. Li, Y.; Liu, Y.-D.; Chen, S.-L.; Chen, X.; Ye, D.-S.; Zhou, X.-Y.; Zhe, J.; Zhang, J. Down-regulation of long non-coding RNAMALAT1inhibits granulosa cell proliferation in endometriosis by up-regulating P21 via activation of the ERK/MAPK pathway. Mol. Hum. Reprod. 2018, 25, 17-29. [CrossRef] [PubMed]

188. Wang, Y.; Wang, X.; Han, L.; Hu, D. LncRNA MALAT1 Regulates the Progression and Cisplatin Resistance of Ovarian Cancer Cells via Modulating miR-1271-5p/E2F5 Axis. Cancer Manag. Res. 2020, 12, 9999-10010. [CrossRef] [PubMed]

189. Wu, X.; Wang, Y.; Zhong, W.; Cheng, H.; Tian, Z. The Long Non-Coding RNA MALAT1 Enhances Ovarian Cancer Cell Stemness by Inhibiting YAP Translocation from Nucleus to Cytoplasm. Med. Sci. Monit. 2020, 26, e922012. [CrossRef] [PubMed]

190. Bai, L.; Wang, A.; Zhang, Y.; Xu, X.; Zhang, X. Knockdown of MALAT1 enhances chemosensitivity of ovarian cancer cells to cisplatin through inhibiting the Notch1 signaling pathway. Exp. Cell Res. 2018, 366, 161-171. [CrossRef] [PubMed]

191. Liu, X.; Zhang, P.; Li, Y.; Zhao, N.; Han, H. The AMPK-mTOR axis requires increased MALAT1 expression for promoting granulosa cell proliferation in endometriosis. Exp. Ther. Med. 2020, 21, 21. [CrossRef]

192. Shi, D.; Zhang, Y.; Lu, R.; Zhang, Y. The long non-coding RNA MALAT1 interacted with miR-218 modulates choriocarcinoma growth by targeting Fbxw. Biomed. Pharmacother. 2018, 97, 543-550. [CrossRef]

193. Al-Rugeebah, A.; Alanazi, M.; Parine, N.R. MEG3: An Oncogenic Long Non-coding RNA in Different Cancers. Pathol. Oncol. Res. 2019, 25, 859-874. [CrossRef] 
194. Zhang, J.-J.; Guo, S.-H.; Jia, B.-Q. Down-regulation of long non-coding RNA MEG3 serves as an unfavorable risk factor for survival of patients with breast cancer. Eur. Rev. Med. Pharmacol. Sci. 2016, 20, 5143-5147.

195. Qin, R.; Chen, Z.; Ding, Y.; Hao, J.; Hu, J.; Guo, F. Long non-coding RNA MEG3 inhibits the proliferation of cervical carcinoma cells through the induction of cell cycle arrest and apoptosis. Neoplasma 2013, 60, 486-492. [CrossRef] [PubMed]

196. Yan, J.; Guo, X.; Xia, J.; Shan, T.; Gu, C.; Liang, Z.; Zhao, W.; Jin, S. MiR-148a regulates MEG3 in gastric cancer by targeting DNA methyltransferase. Med. Oncol. 2014, 31, 879. [CrossRef]

197. Lu, K.-H.; Li, W.; Liu, X.-H.; Sun, M.; Zhang, M.-L.; Wu, W.-Q.; Xie, W.-P.; Hou, Y.-Y. Long non-coding RNA MEG3 inhibits NSCLC cells proliferation and induces apoptosis by affecting p53 expression. BMC Cancer 2013, 13, 461. [CrossRef] [PubMed]

198. Sheng, X.; Li, J.; Yang, L.; Chen, Z.; Zhao, Q.; Tan, L.; Zhou, Y.; Li, J.; Chen, Z.; Zhao, Q.; et al. Promoter hypermethylation influences the suppressive role of maternally expressed 3, a long non-coding RNA, in the development of epithelial ovarian cancer. Oncol. Rep. 2014, 32, 277-285. [CrossRef] [PubMed]

199. Liu, Y.; Xu, Y.; Ding, L.; Yu, L.; Zhang, B.; Wei, D. LncRNA MEG3 suppressed the progression of ovarian cancer via sponging miR-30e-3p and regulating LAMA4 expression. Cancer Cell Int. 2020, 20, 181. [CrossRef] [PubMed]

200. Wang, J.; Xu, W.; He, Y.; Xia, Q.; Liu, S. LncRNA MEG3 impacts proliferation, invasion, and migration of ovarian cancer cells through regulating PTEN. Inflamm. Res. 2018, 67, 927-936. [CrossRef]

201. Buttarelli, M.; De Donato, M.; Raspaglio, G.; Babini, G.; Ciucci, A.; Martinelli, E.; Baccaro, P.; Pasciuto, T.; Fagotti, A.; Scambia, G.; et al. Clinical Value of lncRNA MEG3 in High-Grade Serous Ovarian Cancer. Cancers 2020, 12, 966. [CrossRef]

202. El-Khazragy, N.; Mohammed, H.F.; Yassin, M.; Elghoneimy, K.; Bayoumy, W.; Hewety, A.; El Magdoub, H.M.; Elayat, W.; Zaki, W.; Safwat, G.; et al. Tissue-based long non-coding RNAs “PVT1, TUG1 and MEG3" signature predicts Cisplatin resistance in ovarian Cancer. Genomics 2020, 112, 4640-4646. [CrossRef]

203. Zhang, J.; Liu, J.; Xu, X.; Li, L. Curcumin suppresses cisplatin resistance development partly via modulating extracellular vesicle-mediated transfer of MEG3 and miR-214 in ovarian cancer. Cancer Chemother. Pharmacol. 2017, 79, 479-487. [CrossRef]

204. Chen, J.; Peng, X.; Dai, Y. The Long Non-Coding RNA (lncRNA) AGAP2-AS1 is Upregulated in Ovarian Carcinoma and Negatively Regulates lncRNA MEG. Med. Sci. Monit. 2019, 25, 4699-4704. [CrossRef]

205. Chen, Z.-J.; Zhang, Z.; Xie, B.-B.; Zhang, H.-Y. Clinical significance of up-regulated lncRNA NEAT1 in prognosis of ovarian cancer. Eur. Rev. Med. Pharmacol. Sci. 2016, 20, 3373-3377.

206. Yang, C.; Li, Z.; Li, Y.; Xu, R.; Wang, Y.; Tian, Y.; Chen, W. Long non-coding RNA NEAT1 overexpression is associated with poor prognosis in cancer patients: A systematic review and meta-analysis. Oncotarget 2016, 8, 2672-2680. [CrossRef]

207. Thankachan, S.; Bhardwaj, B.K.; Venkatesh, T.; Suresh, P.S. Long Non-coding RNA NEAT1 as an Emerging Biomarker in Breast and Gynecologic Cancers: A Systematic Overview. Reprod. Sci. 2021, 28, 2436-2447. [CrossRef]

208. Ding, N.; Wu, H.; Tao, T.; Peng, E. NEAT1 regulates cell proliferation and apoptosis of ovarian cancer by miR-34a-5p/BCL. OncoTargets Ther. 2017, 10, 4905-4915. [CrossRef]

209. Chai, Y.; Liu, J.; Zhang, Z.; Liu, L. HuR-regulated lnc RNA NEAT 1 stability in tumorigenesis and progression of ovarian cancer. Cancer Med. 2016, 5, 1588-1598. [CrossRef]

210. Liu, Y.; Wang, Y.; Fu, X.; Lu, Z. Long non-coding RNA NEAT1 promoted ovarian cancer cells' metastasis through regulation of miR-382-3p/ROCK1 axial. Cancer Sci. 2018, 109, 2188-2198. [CrossRef] [PubMed]

211. Yong, W.; Yu, D.; Jun, Z.; Yachen, D.; Weiwei, W.; Midie, X.; Xingzhu, J.; Xiaohua, W. Long noncoding RNA NEAT1, regulated by LIN28B, promotes cell proliferation and migration through sponging miR-506 in high-grade serous ovarian cancer. Cell Death Dis. 2018, 9, 861. [CrossRef] [PubMed]

212. Luo, M.; Zhang, L.; Yang, H.; Luo, K.; Qing, C. Long non-coding RNA NEAT1 promotes ovarian cancer cell invasion and migration by interacting with miR-1321 and regulating tight junction protein 3 expression. Mol. Med. Rep. 2020, 22, 3429-3439. [CrossRef] [PubMed]

213. Xu, H.; Sun, X.; Huang, Y.; Si, Q.; Li, M. Long non-coding RNA NEAT1 modifies cell proliferation, colony formation, apoptosis, migration and invasion via the miR-4500/BZW1 axis in ovarian cancer. Mol. Med. Rep. 2020, 22, 3347-3357. [CrossRef] [PubMed]

214. Yuan, J.; Yi, K.; Yang, L. LncRNA NEAT1 promotes proliferation of ovarian cancer cells and angiogenesis of co-incubated human umbilical vein endothelial cells by regulating FGF9 through sponging miR-365: An Experimental Study. Medicine 2021, 100, e23423. [CrossRef]

215. Zhu, M.; Yang, L.; Wang, X. NEAT1 Knockdown Suppresses the Cisplatin Resistance in Ovarian Cancer by Regulating miR-7705p/PARP1 Axis. Cancer Manag. Res. 2020, 12, 7277-7289. [CrossRef]

216. An, J.; Lv, W.; Zhang, Y. LncRNA NEAT1 contributes to paclitaxel resistance of ovarian cancer cells by regulating ZEB1 expression via miR-194. OncoTargets Ther. 2017, 10, 5377-5390. [CrossRef]

217. Nitusca, D.; Marcu, A.; Dema, A.; Balacescu, L.; Balacescu, O.; Bardan, R.; Cumpanas, A.; Sirbu, I.; Petrut, B.; Seclaman, E.; et al. Long Noncoding RNA NEAT1 as a Potential Candidate Biomarker for Prostate Cancer. Life 2021, 11, 320. [CrossRef]

218. Swellam, M.; El Magdoub, H.M.; Shawki, M.; Adel, M.; Hefny, M.M.; El-Shazly, S.S. Clinical impact of LncRNA XIST and LncRNA NEAT1 for diagnosis of high-risk group breast cancer patients. Curr. Probl. Cancer 2021, 100709. [CrossRef]

219. Pils, D.; Tong, D.; Hager, G.; Obermayr, E.; Aust, S.; Heinze, G.; Kohl, M.; Schuster, E.; Wolf, A.; Sehouli, J.; et al. A combined blood based gene expression and plasma protein abundance signature for diagnosis of epithelial ovarian cancer-A study of the OVCAD consortium. BMC Cancer 2013, 13, 178. [CrossRef] 
220. Hong, H.-H.; Hou, L.-K.; Pan, X.; Wu, C.-Y.; Huang, H.; Li, B.; Nie, W. Long non-coding RNA UCA1 is a predictive biomarker of cancer. Oncotarget 2016, 7, 44442-44447. [CrossRef] [PubMed]

221. Yang, Y.; Jiang, Y.; Wan, Y.; Zhang, L.; Qiu, J.; Zhou, S.; Cheng, W. UCA1 functions as a competing endogenous RNA to suppress epithelial ovarian cancer metastasis. Tumor Biol. 2016, 37, 10633-10641. [CrossRef] [PubMed]

222. Moss, N.M.; Barbolina, M.V.; Liu, Y.; Sun, L.; Munshi, H.G.; Stack, M.S. Ovarian Cancer Cell Detachment and Multicellular Aggregate Formation Are Regulated by Membrane Type 1 Matrix Metalloproteinase: A Potential Role in I.p. Metastatic Dissemination. Cancer Res. 2009, 69, 7121-7129. [CrossRef] [PubMed]

223. Lin, X.; Spindler, T.J.; Fonseca, M.A.D.S.; Corona, R.I.; Seo, J.-H.; Dezem, F.S.; Li, L.; Lee, J.M.; Long, H.W.; Sellers, T.A.; et al Super-Enhancer-Associated LncRNA UCA1 Interacts Directly with AMOT to Activate YAP Target Genes in Epithelial Ovarian Cancer. iScience 2019, 17, 242-255. [CrossRef] [PubMed]

224. Qiu, Y.R.; Zhao, M.Y.; Sun, L.; Yang, B.C.; Hei, K.W.; Du, X.; Li, Y.M. Expression of IncRNA UCA1 in ovarian cancer and its clinical significance. Eur. J. Gynaecol. Oncol. 2017, 38, 191-195.

225. Zhang, L.; Cao, X.; Zhang, L.; Zhang, X.; Sheng, H.; Tao, K. UCA1 overexpression predicts clinical outcome of patients with ovarian cancer receiving adjuvant chemotherapy. Cancer Chemother. Pharmacol. 2016, 77, 629-634. [CrossRef]

226. Wang, F.; Zhou, J.; Xie, X.; Hu, J.; Chen, L.; Hu, Q.; Guo, H.; Yu, C. Involvement of SRPK1 in cisplatin resistance related to long non-coding RNA UCA1 in human ovarian cancer cells. Neoplasma 2015, 62, 432-438. [CrossRef]

227. Li, Z.; Niu, H.; Qin, Q.; Yang, S.; Wang, Q.; Yu, C.; Wei, Z.; Jin, Z.; Wang, X.; Yang, A.; et al. IncRNA UCA1 Mediates Resistance to Cisplatin by Regulating the miR-143/FOSL2-Signaling Pathway in Ovarian Cancer. Mol. Ther.-Nucleic Acids 2019, $17,92-101$. [CrossRef]

228. Li, Z.-Y.; Wang, X.-L.; Dang, Y.; Zhu, X.-Z.; Zhang, Y.-H.; Cai, B.-X.; Zheng, L. Long non-coding RNA UCA1 promotes the progression of paclitaxel resistance in ovarian cancer by regulating the miR-654-5p/SIK2 axis. Eur. Rev. Med. Pharmacol. Sci. 2020, 24, 591-603. [CrossRef]

229. Wang, J.; Ye, C.; Liu, J.; Hu, Y. UCA1 confers paclitaxel resistance to ovarian cancer through miR-129/ABCB1 axis. Biochem. Biophys. Res. Commun. 2018, 501, 1034-1040. [CrossRef]

230. Pintacuda, G.; Young, A.N.; Cerase, A. Function by Structure: Spotlights on Xist Long Non-coding RNA. Front. Mol. Biosci. 2017, 4, 90. [CrossRef] [PubMed]

231. Zhu, J.; Kong, F.; Xing, L.; Jin, Z.; Li, Z. Prognostic and clinicopathological value of long noncoding RNA XIST in cancer. Clin. Chim. Acta 2018, 479, 43-47. [CrossRef] [PubMed]

232. Hu, Y.; Mei, X.; Tang, D. Long non-coding RNA XIST is down-regulated and correlated to better prognosis in ovarian cancer. Math. Biosci. Eng. 2020, 17, 2070-2081. [CrossRef] [PubMed]

233. Zuo, K.; Zhao, Y.; Zheng, Y.; Chen, D.; Liu, X.; Du, S.; Liu, Q. Long non-coding RNA XIST promotes malignant behavior of epithelial ovarian cancer. OncoTargets Ther. 2019, 12, 7261-7267. [CrossRef] [PubMed]

234. Guo, T.; Yuan, D.; Zhang, W.; Zhu, D.; Xiao, A.; Mao, G.; Jiang, W.; Lin, M.; Wang, J. Upregulation of long noncoding RNA XIST has anticancer effects on ovarian cancer through sponging miR-106a. Hum. Cell 2021, 34, 579-587. [CrossRef]

235. Jiang, R.; Zhang, H.; Zhou, J.; Wang, J.; Xu, Y.; Zhang, H.; Gu, Y.; Fu, F.; Shen, Y.; Zhang, G.; et al. Inhibition of long non-coding RNA XIST upregulates microRNA-149-3p to repress ovarian cancer cell progression. Cell Death Dis. 2021, 12, 145. [CrossRef] [PubMed]

236. Wang, C.; Qi, S.; Xie, C.; Li, C.; Wang, P.; Liu, D. Upregulation of long non-coding RNA XIST has anticancer effects on epithelial ovarian cancer cells through inverse downregulation of hsa-miR-214-3p. J. Gynecol. Oncol. 2018, 29, e99. [CrossRef] [PubMed]

237. Zhao, Y.; Yu, Z.; Ma, R.; Zhang, Y.; Zhao, L.; Yan, Y.; Lv, X.; Zhang, L.; Su, P.; Bi, J.; et al. lncRNA-Xist/miR-101-3p/KLF6/C/EBP $\alpha$ axis promotes TAM polarization to regulate cancer cell proliferation and migration. Mol. Ther.-Nucleic Acids 2021, $23,536-551$. [CrossRef] [PubMed]

238. Li, Q.; Zhang, C.; Chen, R.; Xiong, H.; Qiu, F.; Liu, S.; Zhang, M.; Wang, F.; Wang, Y.; Zhou, X.; et al. Disrupting MALAT1/miR200c sponge decreases invasion and migration in endometrioid endometrial carcinoma. Cancer Lett. 2016, 383, 28-40. [CrossRef] [PubMed]

239. Wang, L.; Yu, M.; Zhao, S. lncRNA MEG3 modified epithelial-mesenchymal transition of ovarian cancer cells by sponging miR-219a-5p and regulating EGFR. J. Cell. Biochem. 2019, 120, 17709-17722. [CrossRef] [PubMed]

240. Tao, P.; Yang, B.; Zhang, H.; Sun, L.; Wang, Y.; Zheng, W. The overexpression of lncRNA MEG3 inhibits cell viability and invasion and promotes apoptosis in ovarian cancer by sponging miR-205-5p. Int. J. Clin. Exp. Pathol. 2020, 13, 869-879.

241. Wang, C.; Yue, S.; Jiang, Y.; Mao, Y.; Zhao, Z.; Liu, X.; Zhang, X.; Pei, D.; Li, Y. LncRNA GAS5 is upregulated in polycystic ovary syndrome and regulates cell apoptosis and the expression of IL-1. J. Ovarian Res. 2020, 13, 145. [CrossRef]

242. Chen, Y.; Zhang, X.; An, Y.; Liu, B.; Lu, M. LncRNA HCP5 promotes cell proliferation and inhibits apoptosis via miR-27a-3p/IGF-1 axis in human granulosa-like tumor cell line KGN. Mol. Cell. Endocrinol. 2020, 503, 110697. [CrossRef] [PubMed]

243. Han, Q.; Zhang, W.; Meng, J.; Ma, L.; Li, A. LncRNA-LET inhibits cell viability, migration and EMT while induces apoptosis by up-regulation of TIMP2 in human granulosa-like tumor cell line KGN. Biomed. Pharmacother. 2018, 100, 250-256. [CrossRef]

244. Chen, M.; Zhang, M.; Xie, L.; Wu, S.; Zhong, Y. LINC00324 facilitates cell proliferation through competing for miR-214-5p in immature ovarian teratocarcinoma. Int. J. Mol. Med. 2020, 47, 397-407. [CrossRef]

245. Yan, C.; Jiang, Y.; Wan, Y.; Zhang, L.; Liu, J.; Zhou, S.; Cheng, W. Long noncoding RNA NBAT-1 suppresses tumorigenesis and predicts favorable prognosis in ovarian cancer. OncoTargets Ther. 2017, 10, 1993-2002. [CrossRef] [PubMed] 
246. Lobo, J.; Leão, R.; Jerónimo, C.; Henrique, R. Liquid Biopsies in the Clinical Management of Germ Cell Tumor Patients: State-of-the-Art and Future Directions. Int. J. Mol. Sci. 2021, 22, 2654. [CrossRef]

247. Wang, X.; Kong, D.; Wang, C.; Ding, X.; Zhang, L.; Zhao, M.; Chen, J.; Xu, X.; Hu, X.; Yang, J.; et al. Circulating microRNAs as novel potential diagnostic biomarkers for ovarian cancer: A systematic review and updated meta-analysis. J. Ovarian Res. 2019, 12, 24. [CrossRef] [PubMed]

248. Tang, X.; Liu, S.; Liu, Y.; Lin, X.; Zheng, T.; Liu, X.; Qiu, J.; Hua, K. Circulating serum exosomal aHIF is a novel prognostic predictor for epithelial ovarian cancer. OncoTargets Ther. 2019, 12, 7699-7711. [CrossRef] [PubMed]

249. Liu, C.; Zhang, H. Serum lncRNA LOXL1-AS1 is a diagnostic and prognostic marker for epithelial ovarian cancer. J. Gene Med. 2020, 22, e3233. [CrossRef] [PubMed]

250. Zhang, L.; Hu, C.; Huang, Z.; Li, Z.; Zhang, Q.; He, Y. In Silico screening of circulating tumor DNA, circulating microRNAs, and long non-coding RNAs as diagnostic molecular biomarkers in ovarian cancer: A comprehensive meta-analysis. PLoS ONE 2021, 16, e0250717. [CrossRef]

251. Markou, A.; Smilkou, S.; Tsaroucha, E.; Lianidou, E. The Effect of Genomic DNA Contamination on the Detection of Circulating Long Non-Coding RNAs: The Paradigm of MALAT1. Diagnostics 2021, 11, 1160. [CrossRef]

252. Cai, T.; Zhang, Q.; Wu, B.; Wang, J.; Li, N.; Zhang, T.; Wang, Z.; Luo, J.; Guo, X.; Ding, X.; et al. LncRNA-encoded microproteins: A new form of cargo in cell culture-derived and circulating extracellular vesicles. J. Extracell. Vesicles 2021, 10, e12123. [CrossRef]

253. Kim, S.S.; Baek, G.O.; Son, J.; Ahn, H.R.; Yoon, M.K.; Cho, H.J.; Yoon, J.H.; Nam, S.W.; Cheong, J.Y.; Eun, J.W. Early detection of hepatocellular carcinoma via liquid biopsy: Panel of small extracellular vesicle-derived long noncoding RNAs identified as markers. Mol. Oncol. 2021, 15, 2715-2731. [CrossRef]

254. Zhu, Y.; Wang, S.; Xi, X.; Zhang, M.; Liu, X.; Tang, W.; Cai, P.; Xing, S.; Bao, P.; Jin, Y.; et al. Integrative analysis of long extracellular RNAs reveals a detection panel of noncoding RNAs for liver cancer. Theranostics 2021, 11, 181-193. [CrossRef]

255. Yu, X.; Wang, R.; Han, C.; Wang, Z.; Jin, X. A Panel of Urinary Long Non-coding RNAs Differentiate Bladder Cancer from Urocystitis. J. Cancer 2020, 11, 781-787. [CrossRef] [PubMed]

256. Zhan, Y.; Du, L.; Wang, L.; Jiang, X.; Zhang, S.; Li, J.; Yan, K.; Duan, W.; Zhao, Y.; Wang, L.; et al. Expression signatures of exosomal long non-coding RNAs in urine serve as novel non-invasive biomarkers for diagnosis and recurrence prediction of bladder cancer. Mol. Cancer 2018, 17, 142. [CrossRef]

257. Barwal, T.S.; Sharma, U.; Vasquez, K.M.; Prakash, H.; Jain, A. A panel of circulating long non-coding RNAs as liquid biopsy biomarkers for breast and cervical cancers. Biochimie 2020, 176, 62-70. [CrossRef] [PubMed]

258. Zhan, X.; Dong, C.; Liu, G.; Li, Y.; Liu, L. Panel of seven long noncoding RNA as a candidate prognostic biomarker for ovarian cancer. OncoTargets Ther. 2017, 10, 2805-2813. [CrossRef]

259. Hyter, S.; Hirst, J.; Pathak, H.; Pessetto, Z.Y.; Koestler, D.C.; Raghavan, R.; Pei, D.; Godwin, A.K. Developing a genetic signature to predict drug response in ovarian cancer. Oncotarget 2018, 9, 14828-14848. [CrossRef]

260. Song, J.; Zhang, W.; Wang, S.; Liu, K.; Song, F.; Ran, L. A panel of 7 prognosis-related long non-coding RNAs to improve platinum-based chemoresistance prediction in ovarian cancer. Int. J. Oncol. 2018, 53, 866-876. [CrossRef]

261. Wang, L.; Hu, Y.; Xiang, X.; Qu, K.; Teng, Y. Identification of long non-coding RNA signature for paclitaxel-resistant patients with advanced ovarian cancer. Oncotarget 2017, 8, 64191-64202. [CrossRef] [PubMed]

262. Arun, G.; Diermeier, S.D.; Spector, D.L. Therapeutic Targeting of Long Non-Coding RNAs in Cancer. Trends Mol. Med. 2018, 24, 257-277. [CrossRef]

263. Jiang, M.-C.; Ni, J.-J.; Cui, W.-Y.; Wang, B.-Y.; Zhuo, W. Emerging roles of lncRNA in cancer and therapeutic opportunities. Am J Cancer Res 2019, 9, 1354-1366.

264. Sandy, P.; Ventura, A.; Jacks, T. Mammalian RNAi: A practical guide. Biotechniques 2005, 39, 215-224. [CrossRef] [PubMed]

265. Taxman, D.J.; Moore, C.B.; Guthrie, E.H.; Huang, M.T.-H. Short Hairpin RNA (shRNA): Design, Delivery, and Assessment of Gene Knockdown. Methods Mol. Biol. 2010, 629, 139-156. [CrossRef]

266. Richard, J.L.C.; Eichhorn, P.J.A. Platforms for Investigating LncRNA Functions. SLAS Technol. 2018, 23, 493-506. [CrossRef] [PubMed]

267. Dizaji, B.F. Strategies to target long non-coding RNAs in cancer treatment: Progress and challenges. Egypt. J. Med. Hum. Genet. 2020, 21, 41. [CrossRef]

268. Walder, R.Y.; Walder, J.A. Role of RNase H in hybrid-arrested translation by antisense oligonucleotides. Proc. Natl. Acad. Sci. USA 1988, 85, 5011-5015. [CrossRef] [PubMed]

269. Arun, G.; Diermeier, S.; Akerman, M.; Chang, K.-C.; Wilkinson, J.E.; Hearn, S.; Kim, Y.; MacLeod, A.R.; Krainer, A.; Norton, L.; et al. Differentiation of mammary tumors and reduction in metastasis uponMalat1lncRNA loss. Genes Dev. 2016, 30, 34-51. [CrossRef]

270. Gutschner, T.; Hämmerle, M.; Eißmann, M.; Hsu, J.; Kim, Y.; Hung, G.; Revenko, A.; Arun, G.; Stentrup, M.; Groß, M.; et al. The Noncoding RNA MALAT1 Is a Critical Regulator of the Metastasis Phenotype of Lung Cancer Cells. Cancer Res. 2013, 73, 1180-1189. [CrossRef] [PubMed]

271. Kurreck, J.; Wyszko, E.; Gillen, C.; Erdmann, V.A. Design of antisense oligonucleotides stabilized by locked nucleic acids. Nucleic Acids Res. 2002, 30, 1911-1918. [CrossRef]

272. Sarma, K.; Levasseur, P.; Aristarkhov, A.; Lee, J.T. Locked nucleic acids (LNAs) reveal sequence requirements and kinetics of Xist RNA localization to the X chromosome. Proc. Natl. Acad. Sci. USA 2010, 107, 22196-22201. [CrossRef] 
273. Zhao, S.; Zhang, X.; Chen, S.; Zhang, S. Natural antisense transcripts in the biological hallmarks of cancer: Powerful regulators hidden in the dark. J. Exp. Clin. Cancer Res. 2020, 39, 187. [CrossRef]

274. Modarresi, F.; Faghihi, M.A.; Lopez-Toledano, M.; Fatemi, R.P.; Magistri, M.; Brothers, S.; Van Der Brug, M.P.; Wahlestedt, C. Inhibition of natural antisense transcripts in vivo results in gene-specific transcriptional upregulation. Nat. Biotechnol. 2012, 30, 453-459. [CrossRef]

275. Kang, M.; Chong, K.Y.; Hartwich, T.M.P.; Bi, F.; Witham, A.K.; Patrick, D.; Morrisson, M.J.; Cady, S.L.; Cerchia, A.P.; Kelk, D.; et al. Ovarian BDNF promotes survival, migration, and attachment of tumor precursors originated from p53 mutant fallopian tube epithelial cells. Oncogenesis 2020, 9, 55. [CrossRef]

276. Hagedorn, P.H.; Persson, R.; Funder, E.D.; Albæk, N.; Diemer, S.L.; Hansen, D.J.; Møller, M.R.; Papargyri, N.; Christiansen, H.; Hansen, B.R.; et al. Locked nucleic acid: Modality, diversity, and drug discovery. Drug Discov. Today 2018, 23, 101-114. [CrossRef] [PubMed]

277. Woo, C.J.; Maier, V.K.; Davey, R.; Brennan, J.; Li, G.; Brothers, J.; Schwartz, B.; Gordo, S.; Kasper, A.; Okamoto, T.R.; et al. Gene activation of SMN by selective disruption of lncRNA-mediated recruitment of PRC2 for the treatment of spinal muscular atrophy. Proc. Natl. Acad. Sci. USA 2017, 114, E1509-E1518. [CrossRef] [PubMed]

278. Bousard, A.; Raposo, A.C.; Zylicz, J.; Picard, C.; Pires, V.B.; Qi, Y.; Gil, C.; Syx, L.; Chang, H.Y.; Heard, E.; et al. The role of Xist -mediated Polycomb recruitment in the initiation of X-chromosome inactivation. EMBO Rep. 2019, 20, e48019. [CrossRef]

279. Antorod, S.W.S.; Joyce, G.F. Mechanism and Utility of an RNA-Cleaving DNA Enzyme. Biochemistry 1998, 37, 13330-13342. [CrossRef]

280. Franzen, S. Expanding the catalytic repertoire of ribozymes and deoxyribozymes beyond RNA substrates. Curr. Opin. Mol. Ther. 2010, 12, 223-232.

281. Sednev, M.V.; Mykhailiuk, V.; Choudhury, P.; Halang, J.; Sloan, K.E.; Bohnsack, M.T.; Höbartner, C. N 6 -Methyladenosine-Sensitive RNA-Cleaving Deoxyribozymes. Angew. Chem. Int. Ed. 2018, 57, 15117-15121. [CrossRef] [PubMed]

282. Wang, X.; Liu, C.; Zhang, S.; Yan, H.; Zhang, L.; Jiang, A.; Liu, Y.; Feng, Y.; Li, D.; Guo, Y.; et al. N6-methyladenosine modification of MALAT1 promotes metastasis via reshaping nuclear speckles. Dev. Cell 2021, 56, 702-715.e8. [CrossRef]

283. Patil, D.P.; Chen, C.K.; Pickering, B.F.; Chow, A.; Jackson, C.; Guttman, M.; Jaffrey, S.R. m6A RNA methylation promotes XIST-mediated transcriptional repression. Nature 2016, 537, 369-373. [CrossRef]

284. Meyer, K.D.; Saletore, Y.; Zumbo, P.; Elemento, O.; Mason, C.E.; Jaffrey, S.R. Comprehensive Analysis of mRNA Methylation Reveals Enrichment in 3' UTRs and near Stop Codons. Cell 2012, 149, 1635-1646. [CrossRef]

285. Ni, W.; Yao, S.; Zhou, Y.; Liu, Y.; Huang, P.; Zhou, A.; Liu, J.; Che, L.; Li, J. Long noncoding RNA GAS5 inhibits progression of colorectal cancer by interacting with and triggering YAP phosphorylation and degradation and is negatively regulated by the m6A reader YTHDF1. Mol. Cancer 2019, 18, 143. [CrossRef]

286. Hu, X.; Peng, W.-X.; Zhou, H.; Jiang, J.; Zhou, X.; Huang, D.; Mo, Y.-Y.; Yang, L. IGF2BP2 regulates DANCR by serving as an N6-methyladenosine reader. Cell Death Differ. 2019, 27, 1782-1794. [CrossRef]

287. Garikipati, V.; Uchida, S. Elucidating the Functions of Non-Coding RNAs from the Perspective of RNA Modifications. Non-Coding RNA 2021, 7, 31. [CrossRef] [PubMed]

288. Chen, F.; Ji, J.; Shen, J.; Lu, X. When Long Noncoding RNAs Meet Genome Editing in Pluripotent Stem Cells. Stem Cells Int. 2017, 2017, 3250624. [CrossRef] [PubMed]

289. Zhen, S.; Li, X. Application of CRISPR-Cas9 for Long Noncoding RNA Genes in Cancer Research. Hum. Gene Ther. 2019, 30, 3-9. [CrossRef] [PubMed]

290. Morelli, E.; Gulla', A.; Amodio, N.; Taiana, E.; Neri, A.; Fulciniti, M.; Munshi, N.C. CRISPR Interference (CRISPRi) and CRISPR Activation (CRISPRa) to Explore the Oncogenic lncRNA Network. Methods Mol. Biol. 2021, 2348, 189-204. [CrossRef] [PubMed]

291. Zhu, S.; Li, W.; Liu, J.; Chen, C.-H.; Liao, Q.; Xu, P.; Xu, H.; Xiao, T.; Cao, Z.; Peng, J.; et al. Genome-scale deletion screening of human long non-coding RNAs using a paired-guide RNA CRISPR-Cas9 library. Nat. Biotechnol. 2016, 34, 1279-1286. [CrossRef]

292. Liu, S.J.; Horlbeck, M.A.; Cho, S.W.; Birk, H.S.; Malatesta, M.; He, D.; Attenello, F.J.; Villalta, J.E.; Cho, M.Y.; Chen, Y.; et al. CRISPRi-based genome-scale identification of functional long noncoding RNA loci in human cells. Science 2017, 355, eaah7111. [CrossRef]

293. Ji, Q.; Cai, G.; Liu, X.; Zhang, Y.; Wang, Y.; Zhou, L.; Sui, H.; Li, Q. MALAT1 regulates the transcriptional and translational levels of proto-oncogene RUNX2 in colorectal cancer metastasis. Cell Death Dis. 2019, 10, 378. [CrossRef]

294. Colognori, D.; Sunwoo, H.; Kriz, A.J.; Wang, C.-Y.; Lee, J.T. Xist Deletional Analysis Reveals an Interdependency between Xist RNA and Polycomb Complexes for Spreading along the Inactive X. Mol. Cell 2019, 74, 101-117.e10. [CrossRef]

295. Attenello, F.J.; Tsung, K.; Bishara, I.; Loh, Y.E.; Chen, T.C. In vivo CRISPR screening for novel noncoding RNA functional targets in glioblastoma models. J. Neurosci. Res. 2021, 99, 2029-2045. [CrossRef]

296. Chen, B.; Deng, S.; Ge, T.; Ye, M.; Yu, J.; Lin, S.; Ma, W.; Songyang, Z. Live cell imaging and proteomic profiling of endogenous NEAT1 lncRNA by CRISPR/Cas9-mediated knock-in. Protein Cell 2020, 11, 641-660. [CrossRef]

297. Zhen, S.; Hua, L.; Liu, Y.-H.; Sun, X.-M.; Jiang, M.-M.; Chen, W.; Zhao, L.; Li, X. Inhibition of long non-coding RNA UCA1 by CRISPR/Cas9 attenuated malignant phenotypes of bladder cancer. Oncotarget 2017, 8, 9634-9646. [CrossRef]

298. Qiu, H.; Wang, X.; Guo, R.; Liu, Q.; Wang, Y.; Yuan, Z.; Li, J.; Shi, H. HOTAIR rs920778 polymorphism is associated with ovarian cancer susceptibility and poor prognosis in a Chinese population. Futur. Oncol. 2017, 13, 347-355. [CrossRef]

299. Wang, V.; Wu, W. MicroRNA-based therapeutics for cancer. BioDrugs 2009, 23, 15-23. [CrossRef] 
300. Lin, H.; Shen, L.; Lin, Q.; Dong, C.; Maswela, B.; Illahi, G.S.; Wu, X. SNHG5 enhances Paclitaxel sensitivity of ovarian cancer cells through sponging miR-23a. Biomed. Pharmacother. 2020, 123, 109711. [CrossRef] [PubMed]

301. Majem, B.; Parrilla, A.; Jiménez, C.J.; Suárez-Cabrera, L.; Barber, M.; Marín, A.; Castellvi, J.; Tamayo, G.; Moreno-Bueno, G.; Ponce, J.; et al. MicroRNA-654-5p suppresses ovarian cancer development impacting on MYC, WNT and AKT pathways. Oncogene 2019, 38, 6035-6050. [CrossRef] [PubMed]

302. Gutschner, T.; Richtig, G.; Haemmerle, M.; Pichler, M. From biomarkers to therapeutic targets-the promises and perils of long non-coding RNAs in cancer. Cancer Metastasis Rev. 2017, 37, 83-105. [CrossRef] [PubMed]

303. Bonetti, A.; Carninci, P. From bench to bedside: The long journey of long non-coding RNAs. Curr. Opin. Syst. Biol. 2017, 3, 119-124. [CrossRef]

304. Watrin, M.; Von Pelchrzim, F.; Dausse, E.; Schroeder, R.; Toulme, J.-J. In Vitro Selection of RNA Aptamers Derived from a Genomic Human Library against the TAR RNA Element of HIV-1. Biochemistry 2009, 48, 6278-6284. [CrossRef]

305. Wang, Y.-L.; Chang, L.-C.; Chen, K.-B.; Wang, S.-C. Aptamer-guided targeting of the intracellular long-noncoding RNA HOTAIR. Am. J. Cancer Res. 2021, 11, 945-954.

306. Xu, A.; Huang, M.-F.; Zhu, D.; Gingold, J.A.; Bazer, D.A.; Chang, B.; Wang, D.; Lai, C.-C.; Lemischka, I.R.; Zhao, R.; et al. LncRNA H19 Suppresses Osteosarcomagenesis by Regulating snoRNAs and DNA Repair Protein Complexes. Front. Genet. 2021, 11, 611823. [CrossRef]

307. Rahbarizadeh, F.; Ahmadvand, D.; Sharifzadeh, Z. Nanobody; an Old Concept and New Vehicle for Immunotargeting. Immunol Investig. 2011, 40, 299-338. [CrossRef] [PubMed]

308. Van Audenhove, I.; Gettemans, J. Nanobodies as Versatile Tools to Understand, Diagnose, Visualize and Treat Cancer. EBioMedicine 2016, 8, 40-48. [CrossRef] [PubMed]

309. Cawez, F.; Duray, E.; Hu, Y.; Vandenameele, J.; Romão, E.; Vincke, C.; Dumoulin, M.; Galleni, M.; Muyldermans, S.; Vandevenne, M. Combinatorial Design of a Nanobody that Specifically Targets Structured RNAs. J. Mol. Biol. 2018, 430, 1652-1670. [CrossRef]

310. Brown, J.A.; Bulkley, D.; Wang, J.; Valenstein, M.L.; Yario, T.A.; Steitz, T.A.; Steitz, J.A. Structural insights into the stabilization of MALAT1 noncoding RNA by a bipartite triple helix. Nat. Struct. Mol. Biol. 2014, 21, 633-640. [CrossRef] [PubMed]

311. Lin, Y.; Schmidt, B.F.; Bruchez, M.P.; McManus, C.J. Structural analyses of NEAT1 lncRNAs suggest long-range RNA interactions that may contribute to paraspeckle architecture. Nucleic Acids Res. 2018, 46, 3742-3752. [CrossRef]

312. Somarowthu, S.; Legiewicz, M.; Chillón, I.; Marcia, M.; Liu, F.; Pyle, A.M. HOTAIR Forms an Intricate and Modular Secondary Structure. Mol. Cell 2015, 58, 353-361. [CrossRef]

313. Donlic, A.; Hargrove, A.E. Targeting RNA in mammalian systems with small molecules. Wiley Interdiscip. Rev. RNA 2018, 9 , e1477. [CrossRef]

314. Fatemi, R.P.; Velmeshev, D.; Faghihi, M.A. De-repressing LncRNA-Targeted Genes to Upregulate Gene Expression: Focus on Small Molecule Therapeutics. Mol. Ther.-Nucleic Acids 2014, 3, e196. [CrossRef]

315. Fatemi, R.P.; Salah-Uddin, S.; Modarresi, F.; Khoury, N.; Wahlestedt, C.; Faghihi, M.A. Screening for Small-Molecule Modulators of Long Noncoding RNA-Protein Interactions Using AlphaScreen. J. Biomol. Screen. 2015, 20, 1132-1141. [CrossRef] [PubMed]

316. Donlic, A.; Morgan, B.S.; Xu, J.L.; Liu, A.; Roble, J.C.; Hargrove, A.E. Discovery of Small Molecule Ligands for MALAT1 by Tuning an RNA-Binding Scaffold. Angew. Chem. Int. Ed. 2018, 57, 13242-13247. [CrossRef] [PubMed]

317. Abulwerdi, F.A.; Xu, W.; Ageeli, A.A.; Yonkunas, M.; Arun, G.; Nam, H.; Schneekloth, J.S.; Dayie, T.K.; Spector, D.; Baird, N.; et al Selective Small-Molecule Targeting of a Triple Helix Encoded by the Long Noncoding RNA, MALAT1. ACS Chem. Biol. 2019, 14, 223-235. [CrossRef] [PubMed]

318. Denichenko, P.; Mogilevsky, M.; Cléry, A.; Welte, T.; Biran, J.; Shimshon, O.; Barnabas, G.D.; Danan-Gotthold, M.; Kumar, S.; Yavin, E.; et al. Specific inhibition of splicing factor activity by decoy RNA oligonucleotides. Nat. Commun. 2019, 10, 1590. [CrossRef] [PubMed]

319. Li, M.-J.; Kim, J.; Li, S.; Zaia, J.; Yee, J.-K.; Anderson, J.; Akkina, R.; Rossi, J.J. Long-Term Inhibition of HIV-1 Infection in Primary Hematopoietic Cells by Lentiviral Vector Delivery of a Triple Combination of Anti-HIV shRNA, Anti-CCR5 Ribozyme, and a Nucleolar-Localizing TAR Decoy. Mol. Ther. 2005, 12, 900-909. [CrossRef] [PubMed]

320. Li, Y.; Tan, Z.; Zhang, Y.; Zhang, Z.; Hu, Q.; Liang, K.; Jun, Y.; Ye, Y.; Li, Y.-C.; Li, C.; et al. A noncoding RNA modulator potentiates phenylalanine metabolism in mice. Science 2021, 373, 662-673. [CrossRef] [PubMed]

321. Mizrahi, A.; Czerniak, A.; Levy, T.; Amiur, S.; Gallula, J.; Matouk, I.; Abu-Lail, R.; Sorin, V.; Birman, T.; De Groot, N.; et al. Development of targeted therapy for ovarian cancer mediated by a plasmid expressing diphtheria toxin under the control of H19 regulatory sequences. J. Transl. Med. 2009, 7, 69. [CrossRef]

322. Lavie, O.; Edelman, D.; Levy, T.; Fishman, A.; Hubert, A.; Segev, Y.; Raveh, E.; Gilon, M.; Hochberg, A. A phase 1/2a, doseescalation, safety, pharmacokinetic, and preliminary efficacy study of intraperitoneal administration of BC-819 (H19-DTA) in subjects with recurrent ovarian/peritoneal cancer. Arch. Gynecol. Obstet. 2017, 295, 751-761. [CrossRef]

323. Abildgaard, C.; Canto, L.M.D.; Steffensen, K.D.; Rogatto, S.R. Long Non-coding RNAs Involved in Resistance to Chemotherapy in Ovarian Cancer. Front. Oncol. 2020, 9, 1549. [CrossRef]

324. Yao, Z.; Zhang, Y.; Xu, D.; Zhou, X.; Peng, P.; Pan, Z.; Xiao, N.; Yao, J.; Li, Z. Research Progress on Long Non-Coding RNA and Radiotherapy. Med. Sci. Monit. 2019, 25, 5757-5770. [CrossRef]

325. Wang, F.; Zuroske, T.; Watts, J.K. RNA therapeutics on the rise. Nat. Rev. Drug Discov. 2020, 19, 441-442. [CrossRef] [PubMed] 
326. Winkle, M.; El-Daly, S.M.; Fabbri, M.; Calin, G.A. Noncoding RNA therapeutics-Challenges and potential solutions. Nat. Rev. Drug Discov. 2021, 20, 629-651. [CrossRef] [PubMed]

327. Peng, L.; Liu, F.; Yang, J.; Liu, X.; Meng, Y.; Deng, X.; Peng, C.; Tian, G.; Zhou, L. Probing lncRNA-Protein Interactions: Data Repositories, Models, and Algorithms. Front. Genet. 2020, 10, 1346. [CrossRef] [PubMed]

328. Yotsukura, S.; Duverle, D.; Hancock, T.; Natsume-Kitatani, Y.; Mamitsuka, H. Computational recognition for long non-coding RNA (lncRNA): Software and databases. Brief. Bioinform. 2017, 18, 9-27. [CrossRef] [PubMed]

329. Pinkney, H.R.; Wright, B.M.; Diermeier, S.D. The lncRNA Toolkit: Databases and In Silico Tools for lncRNA Analysis. Non-Coding RNA 2020, 6, 49. [CrossRef]

330. Kozomara, A.; Birgaoanu, M.; Griffiths-Jones, S. miRBase: From microRNA sequences to function. Nucleic Acids Res. 2019, 47, D155-D162. [CrossRef]

331. RNAcentral Consortium; Sweeney, B.; Petrov, A.; Ribas, C.; Finn, R.D.; Bateman, A.; Szymanski, M.; Karlowski, W.M.; Seemann, S.; Gorodkin, J.; et al. RNAcentral 2021: Secondary structure integration, improved sequence search and new member databases. Nucleic Acids Res. 2021, 49, D212-D220. [CrossRef]

332. Volders, P.-J.; Anckaert, J.; Verheggen, K.; Nuytens, J.; Martens, L.; Mestdagh, P.; Vandesompele, J. LNCipedia 5: Towards a reference set of human long non-coding RNAs. Nucleic Acids Res. 2019, 47, D135-D139. [CrossRef]

333. Ma, L.; Cao, J.; Liu, L.; Du, Q.; Li, Z.; Zou, D.; Bajic, V.B.; Zhang, Z. LncBook: A curated knowledgebase of human long non-coding RNAs. Nucleic Acids Res. 2019, 47, D128-D134. [CrossRef]

334. Amaral, P.P.; Clark, M.B.; Gascoigne, D.K.; Dinger, M.E.; Mattick, J.S. lncRNAdb: A reference database for long noncoding RNAs. Nucleic Acids Res. 2011, 39, D146-D151. [CrossRef]

335. Bhartiya, D.; Pal, K.; Ghosh, S.; Kapoor, S.; Jalali, S.; Panwar, B.; Jain, S.; Sati, S.; Sengupta, S.; Sachidanandan, C.; et al. lncRNome: A comprehensive knowledgebase of human long noncoding RNAs. Database 2013, 2013, bat034. [CrossRef]

336. The GTEx Consortium The GTEx Consortium atlas of genetic regulatory effects across human tissues. Science 2020, 369, 1318-1330. [CrossRef]

337. Clough, E.; Barrett, T. The Gene Expression Omnibus Database. Methods Mol. Biol. 2016, 1418, 93-110. [CrossRef]

338. Weinstein, J.N.; Collisson, E.A.; Mills, G.B.; Shaw, K.R.M.; Ozenberger, B.A.; Ellrott, K.; Shmulevich, I.; Sander, C.; Stuart, J.M. The Cancer Genome Atlas Pan-Cancer analysis project. Nat. Genet. 2013, 45, 1113-1120. [CrossRef]

339. Papatheodorou, I.; Moreno, P.; Manning, J.; Fuentes, A.M.-P.; George, N.; Fexova, S.; Fonseca, N.; Füllgrabe, A.; Green, M.; Huang, N.; et al. Expression Atlas update: From tissues to single cells. Nucleic Acids Res. 2019, 48, D77-D83. [CrossRef] [PubMed]

340. Fang, S.; Zhang, L.; Guo, J.; Niu, Y.; Wu, Y.; Li, H.; Zhao, L.; Li, X.; Teng, X.; Sun, X.; et al. NONCODEV5: A comprehensive annotation database for long non-coding RNAs. Nucleic Acids Res. 2018, 46, D308-D314. [CrossRef] [PubMed]

341. Dinger, M.E.; Pang, K.C.; Mercer, T.R.; Crowe, M.L.; Grimmond, S.M.; Mattick, J.S. NRED: A database of long noncoding RNA expression. Nucleic Acids Res. 2009, 37, D122-D126. [CrossRef] [PubMed]

342. Li, Z.; Liu, L.; Jiang, S.; Li, Q.; Feng, C.; Du, Q.; Zou, D.; Xiao, J.; Zhang, Z.; Ma, L. LncExpDB: An expression database of human long non-coding RNAs. Nucleic Acids Res. 2021, 49, D962-D968. [CrossRef] [PubMed]

343. Lv, D.; Xu, K.; Jin, X.; Li, J.; Shi, Y.; Zhang, M.; Jin, X.; Li, Y.; Xu, J.; Li, X. LncSpA: LncRNA Spatial Atlas of Expression across Normal and Cancer Tissues. Cancer Res. 2020, 80, 2067-2071. [CrossRef]

344. Li, J.; Han, L.; Roebuck, P.; Diao, L.; Liu, L.; Yuan, Y.; Weinstein, J.N.; Liang, H. TANRIC: An Interactive Open Platform to Explore the Function of lncRNAs in Cancer. Cancer Res. 2015, 75, 3728-3737. [CrossRef]

345. Bao, Z.; Yang, Z.; Huang, Z.; Zhou, Y.; Cui, Q.; Dong, D. LncRNADisease 2.0: An updated database of long non-coding RNA-associated diseases. Nucleic Acids Res. 2019, 47, D1034-D1037. [CrossRef]

346. Gao, Y.; Shang, S.; Guo, S.; Li, X.; Zhou, H.; Liu, H.; Sun, Y.; Wang, J.; Wang, P.; Zhi, H.; et al. Lnc2Cancer 3.0: An updated resource for experimentally supported lncRNA/circRNA cancer associations and web tools based on RNA-seq and scRNA-seq data. Nucleic Acids Res. 2021, 49, D1251-D1258. [CrossRef]

347. Miao, Y.-R.; Liu, W.; Zhang, Q.; Guo, A.-Y. lncRNASNP2: An updated database of functional SNPs and mutations in human and mouse lncRNAs. Nucleic Acids Res. 2018, 46, D276-D280. [CrossRef] [PubMed]

348. Ren, C.; An, G.; Zhao, C.; Ouyang, Z.; Bo, X.; Shu, W. Lnc2Catlas: An atlas of long noncoding RNAs associated with risk of cancers. Sci. Rep. 2018, 8, 1909. [CrossRef]

349. Paraskevopoulou, M.D.; Karagkouni, D.; Vlachos, I.S.; Tastsoglou, S.; Hatzigeorgiou, A.G. microCLIP super learning framework uncovers functional transcriptome-wide miRNA interactions. Nat. Commun. 2018, 9, 3601. [CrossRef] [PubMed]

350. Kirk, J.M.; Kim, S.O.; Inoue, K.; Smola, M.J.; Lee, D.M.; Schertzer, M.D.; Wooten, J.S.; Baker, A.R.; Sprague, D.; Collins, D.W.; et al. Functional classification of long non-coding RNAs by k-mer content. Nat. Genet. 2018, 50, 1474-1482. [CrossRef]

351. Zhou, Y.-K.; Shen, Z.-A.; Yu, H.; Luo, T.; Gao, Y.; Du, P.-F. Predicting lncRNA-Protein Interactions With miRNAs as Mediators in a Heterogeneous Network Model. Front. Genet. 2020, 10, 1341. [CrossRef]

352. Ma, L.; Cao, J.; Liu, L.; Li, Z.; Shireen, H.; Pervaiz, N.; Batool, F.; Raza, R.Z.; Zou, D.; Bao, Y.; et al. Community Curation and Expert Curation of Human Long Noncoding RNAs with LncRNAWiki and LncBook. Curr. Protoc. Bioinform. 2019, 67, e82. [CrossRef] [PubMed]

353. Tripathi, M.K.; Doxtater, K.; Keramatnia, F.; Zacheaus, C.; Yallapu, M.; Jaggi, M.; Chauhan, S.C. Role of IncRNAs in ovarian cancer: Defining new biomarkers for therapeutic purposes. Drug Discov. Today 2018, 23, 1635-1643. [CrossRef] [PubMed] 